NASA Technical Memorandum 101346

\title{
Molten Salt Corrosion of $\mathrm{SiC}$ and $\mathrm{Si}_{3} \mathrm{~N}_{4}$
}

\author{
(AASA-TM-1C1340) NCITEA SALI CCEFCSICN CF NO9-11912 \\ SIC ARL SI3A4 (AISA) $68 \mathrm{~F}$ CSCL $11 \mathrm{D}$ \\ $63 / 27 \quad \begin{array}{ll}\text { Unclas } \\ 0174577\end{array}$
}

Nathan S. Jacobson, James L. Smialek, and Dennis S. Fox

Lewis Research Center

Cleveland, Ohio

November 1988 



\title{
MOLTEN SALT CORROSION OF SIC AND $\mathrm{Si}_{3} \mathrm{~N}_{4}$
}

\author{
Nathan S. Jacobson, James L. Smialek, and Dennis S. Fox \\ National Aeronautics and Space Administration \\ Lewis Research Center \\ Cleveland, Ohio $\mathbf{4 4 1 3 5}$
}

\begin{abstract}
Industrial systems such as heat engines and heat exchangers involve harsh environments. The structural materials are subjected to high temperatures and as well as corrosive gases and condensed phases. Past experience with metal alloys has shown that these condensed phases can be particularly corrosive and are often the limiting factor in the operation of these systems. In a heat engine the most common condensed corrodent is $\mathrm{Na}_{2} \mathrm{SO}_{4}$ whereas in a heat exchanger an oxide slag may be present. The primary emphasis of this chapter is on $\mathrm{Na}_{2} \mathrm{SO}_{4}$ induced corrosion, however similarities and differences to oxide slag corrosion are also discussed.

The extensive research on corrosion of metal alloys has led to understanding and controlling corrosion for these materials. Currently silicon based ceramics are prime candidates for the applications discussed above. Therefore it important to understand the effects of condensed phase deposits on this emerging class of high temperature materials. Both the thermodynamics and kinetics of the
\end{abstract}


corrosion reactions are discussed. The effect of these

corrosion reactions on the microstructure and strength of the ceramic is also examined. Finally some control strategies

for corrosion of silicon based ceramics are explored. 


\section{Introduction}

Silicon based ceramics such as $\mathrm{SiC}$ and $\mathrm{Si}_{3} \mathrm{~N}_{4}$, and composites based on these materials, are currently prime candidates for high temperature applications such as heat engines and heat exchanger tubes. These ceramics offer a number of advantages which include high strength at temperatures up to $1400^{\circ} \mathrm{C}$, good thermal shock resistance, excellent oxidation resistance, light weight, and compositions based on abundant raw materials.

In selecting a material, a prime consideration is its resistance to the chemical environment encountered in the specific application. As mentioned, silicon based ceramics show excellent oxidation resistance. However, actual heat engine or heat exchanger environments often contain more than pure oxygen. Additional species include other oxidants such as chlorine and sulfur dioxide as well as condensed phase deposits. The primary focus of this chapter is on condensed phase deposits. Table I lists potential applications for silicon based ceramics, the temperature ranges, and the possible condensed phase corrodents. Typically these deposits are alkali metal salts and/or oxide slags. It should be noted that corrosion is typically a problem above 
the melting point of the deposit. When the deposit is fluid, it spreads readily and rapid transport through the film permits accelerated chemical processes to occur.

It is appropriate to briefly discuss the origin of these deposits. In a heat engine small amounts of sodium ingested from a marine environment or from fuel impurities react with sulfur in the fuel to form sodium sulfatel:

$$
\begin{aligned}
2 \mathrm{NaCl}(\mathrm{g})+ & \mathrm{SO}_{2}(\mathrm{~g})+1 / 2 \mathrm{O}_{2}(\mathrm{~g})+ \\
& \mathrm{H}_{2} \mathrm{O}(\mathrm{g})= \\
& \mathrm{Na}_{2} \mathrm{SO}_{4}(\mathrm{l})+2 \mathrm{HCl}(\mathrm{g})
\end{aligned}
$$

This process and the resulting corrosion can be a problem for metals and has been extensively studied. 2 In addition some fuels may contain vanadium impurities, which form vanadate deposits. Under some conditions these vanadate deposits can be controlled with additives. In a coal combustion situation, a slag containing various oxides forms. ${ }^{3}$ In an industrial furnace, such as a fluxing aluminum reclamation furnace, salts may be used as part of the process. 4 other potential applications include magnetohydrodynamic (MHD) processes, where the gas stream is intentionally seeded with potassium salts ${ }^{5}$, and fuel cells which contain molten salts. 6

Before examining actual corrosion processes, the various types of silicon based ceramics should be discussed. Some common types are listed in Table II. Some types of SiC and $\mathrm{Si}_{3} \mathrm{~N}_{4}$, such as the CVD materials, are extremely pure. However most of the commercial materials contain additives to 
promote densification. These additives are often an important factor in the high temperature behavior of these materials.

A survey of research $8-84$ on the corrosion of silicon based ceramics is given in Table III, which is divided according to application. The earlier studies (1952-1974) center on the use of molten salts as an etchant. These studies show that basic molten salts selectively attack structural discontinuities in Sic. This observation is important in understanding the corrosive action of molten salts in actual applications. Most of the subsequent research in ceramic corrosion deals with heat engines. This is because corrosion of metal alloys in engines had proven to be such a formidable problem. ${ }^{2}$ Most of these studies center on $\mathrm{Na}_{2} \mathrm{SO}_{4}$ induced corrosion of $\mathrm{SiC}$ and $\mathrm{Si}_{3} \mathrm{~N}_{4}$; only limited information on vanadate induced corrosion of $\mathrm{SiC}$ and $\mathrm{Si}_{3} \mathrm{~N}_{4}$ was found.

Table III includes headings for the type of ceramic examined, the corrodent, and the experimental technique. Three major experimental methods are listed in the "Technique" column--burner tests wherein the flame is seeded with salt, laboratory crucible tests, and laboratory film tests. The techique used depends on the application being modeled and the type of information sought. Burner tests may accurately model the actual application, but it is difficult 
to control the experimental parameters and determine a chemical mechanism of corrosion. Furthermore, these tests require much more apparatus than a laboratory study. In a laboratory crucible test, the sample is covered by a deep melt. These types of studies dominated the early corrosion literature. This type of test may be appropriate for a study of coal slag corrosion, but for a heat engine corrosion study, the oxygen potential at the melt/specimen interface may be unrealistically low. In a laboratory film study the specimen is coated with a film of the corrosive salt. The various parameters, such as gas composition at the melt/specimen interface, can then be more easily controlled. Current studies aimed at a fundamental understanding of heat engine corrosion center on thin films.

The primary emphasis of this chapter will be corrosion by sodium sulfate in heat engines. However many of the principals for this type of corrosion apply to other types of corrosion. Where possible, unifying concepts will be discussed.

\section{Chemistry}

Silicon based ceramics are inherently unstable in oxygen and rely on a thin film of $\mathrm{SiO}_{2}$ for oxidation protection. 
This film provides good protection to about $1500^{\circ} \mathrm{C}$. Corrosion processes may destroy this oxide film, exposing the material to extensive attack.

Consider corrosion by sodium sulfate in a heat engine application. This occurs in two steps--deposition of $\mathrm{Na}_{2} \mathrm{SO}_{4}$ on an engine part and the actual corrosion process. As mentioned, sodium sulfate forms by Equation (1). Typically corrosion occurs in a temperature regime bounded by the melting point of sodium sulfate $\left(884^{\circ} \mathrm{C}\right)$ and the dew point for deposition of sodium sulfate. The dew point is a function of pressure and concentration and can be calculated from thermochemical equilibrium codes. 85 Dew points for a variety of conditions are shown in Table IV. Higher operating temperatures decrease the likelihood of deposition, since no deposit will form if the thermodynamic dew point is exceeded. However higher operating pressures increase the likelihood of deposition since higher pressures increase the dew point. Since future heat engines are expected to operate at both higher temperatures and pressures, the possiblity of deposition and subsequent attack must be carefully considered.

Figure $1(a)$ shows a coupon of $\operatorname{SASC}(B, C)$ exposed in a burner rig with no salt. Essentially no attack has occurred and the coupon is nearly indistinguishable from the starting material. However, when only $4 \mathrm{ppm}$ sodium as sodium chloride 
is added to the flame, a large glassy deposit forms as shown in Figure $1(\mathrm{~b}) .47$ This glassy material is shown as a polished cross section in Figure 2. The associated $x$-ray maps show an even distribution of $\mathrm{Si}, \mathrm{O}$, and $\mathrm{Na}$, suggesting a sodium silicate glass. Thus the likely reaction scheme is:

$$
\begin{aligned}
& \mathrm{SiC}(\mathrm{s})+3 / 2 \mathrm{O}_{2}(\mathrm{~g})=\mathrm{SiO}_{2}(\mathrm{~s})+\mathrm{CO}(\mathrm{g}) \\
& \mathrm{xSiO}_{2}(\mathrm{~s})+\mathrm{Na}_{2} \mathrm{SO}_{4}(\mathrm{l})=\mathrm{Na}_{2} \mathrm{O} \cdot \mathrm{x}\left(\mathrm{SiO}_{2}\right)(\mathrm{l})+\mathrm{SO}_{3}(\mathrm{~g})
\end{aligned}
$$

The important point to note is that the solid, protective silica layer has been dissolved to a form a liquid, non-protective sodium silicate layer. The faster transport rates through this liquid layer allow extensive corrosion of the ceramic. The $\mathrm{Na}_{2} \mathrm{O}-\mathrm{SiO}_{2}$ phase diagram 86 is shown in Figure 3. Note that a small amount of $\mathrm{Na}_{2} \mathrm{O}$ would be expected to form some liquid silicate.

Reaction (3) can be written more fundamentally as:

$$
\begin{gathered}
\mathrm{Na}_{2} \mathrm{SO}_{4}(\mathrm{l})=\mathrm{Na}_{2} \mathrm{O}(\mathrm{s})+\mathrm{sO}_{3}(\mathrm{~g}) \\
\mathrm{xSiO}_{2}(\mathrm{~s})+\mathrm{Na}_{2} \mathrm{O}(\mathrm{s})=\mathrm{Na}_{2} \mathrm{O} \cdot \mathrm{x}\left(\mathrm{SiO}_{2}\right)(1)
\end{gathered}
$$

This indicates that the key reactant is $\mathrm{Na}_{2} \mathrm{O}$. The

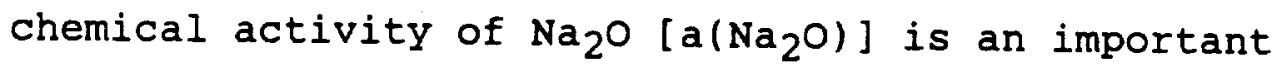
parameter. In analogy with Lewis acid-base concepts, a high $\mathrm{a}\left(\mathrm{Na}_{2} \mathrm{O}\right)$ salt is termed a basic molten salt and a low a( $\left.\mathrm{Na}_{2} \mathrm{O}\right)$ is termed an acidic molten salt. From reaction (5) a threshold a( $\left.\mathrm{Na}_{2} \mathrm{O}\right)$ for silica dissolution can be calculated. The stable silicates, as a function of $a\left(\mathrm{Na}_{2} \mathrm{O}\right)$ at $1000{ }^{\circ} \mathrm{C}$, are shown in Figure 4.87 Note that silica dissolution only 
occurs for larger $\mathrm{a}\left(\mathrm{Na}_{2} \mathrm{O}\right)$. This type of dissolution, wherein the silica accepts an oxide anion, is termed basic dissolution. Unlike other oxides, silica does not undergo acidic dissolution, wherein the oxide donates an oxide anion to the melt. 88 Thus a well defined regime for silica dissolution as a function of $\mathrm{a}\left(\mathrm{Na}_{2} \mathrm{O}\right)$ and temperature can be easily calculated.

This regime is calculated as follows. The important boundary to examine is between $\mathrm{SiO}_{2}$ and the first stable silicate -- $\mathrm{Na}_{2} \mathrm{O} \cdot 2\left(\mathrm{SiO}_{2}\right)$, as shown in Figure 2. Taking the activity of $\mathrm{SiO}_{2}$ and the activity of $\mathrm{Na}_{2} \mathrm{O} \cdot 2\left(\mathrm{SiO}_{2}\right)$ to both be unity, the minimum $a\left(\mathrm{Na}_{2} \mathrm{O}\right)$ for dissolution can be calculated from reaction (5) with $x=2$ :

$$
\text { RT } \log a\left(\mathrm{Na}_{2} \mathrm{O}\right)=\mathrm{G}(\text { reaction }(5))
$$

Here $R$ is the gas constant and $T$ is temperature in degrees Kelvin. As reaction (4) shows, the activity of $\mathrm{Na}_{2} \mathrm{O}$ is set by the partial pressure of $\mathrm{SO}_{3}(g)--\mathrm{p}\left(\mathrm{SO}_{3}\right)$. Taking the activity of $\mathrm{Na}_{2} \mathrm{SO}_{4}$ to be unity:

$$
\mathrm{G}=-\mathrm{RT} \ln \mathrm{p}\left(\mathrm{SO}_{3}\right) \quad \mathrm{a}\left(\mathrm{Na}_{2} \mathrm{O}\right)
$$

Thus from the minimum $a\left(\mathrm{Na}_{2} \mathrm{O}\right)$ for dissolution, a maximum $\mathrm{p}\left(\mathrm{SO}_{3}\right)$ can be calculated. This is shown as an upper boundary for corrosion in Figure $5(a)$ and (b).53 Using the NASA Chemical Equilibrium Code ${ }^{85}$, the partial pressure of $\mathrm{SO}_{3}$ in a heat engine can be calculated. The parameters which determine this include temperature, pressure, and sulfur 
content in the fuel. The results for Jet A fuel $(\sim 0.058 \mathrm{~S})$ are shown in Figure $5(a)$ and the results for No. 2 Diesel fuel $(\sim 0.5 \% \mathrm{~S})$ are shown in Figure $5(\mathrm{~b})$. When the $\mathrm{p}\left(\mathrm{SO}_{3}\right)$ in the engine is below the upper boundary of $\mathrm{p}\left(\mathrm{SO}_{3}\right)$ for dissolution, corrosion is predicted. Note that with Jet A fuel this occurs at about $-995^{\circ} \mathrm{C}$, whereas with No. 2 Diesel fuel this occurs at about $-1080^{\circ} \mathrm{C}$.

As mentioned, corrosion occurs between well defined temperature limits. The lower limit is the melting point for $\mathrm{Na}_{2} \mathrm{SO}_{4}--884^{\circ} \mathrm{C}$. The upper limit is the dew point for $\mathrm{Na}_{2} \mathrm{SO}_{4}$ deposition, as shown in Table IV. These are shown on Figures $5(a)$ and (b). Note that dissolution can occur for the higher sulfur fuel above the dew point. Thus corrosion is not predicted for No. 2 Diesel fuel under the conditions described by Figures $5(a)$ and $5(b)$.

This type of diagram can be generated for a variety of pressures and sodium and sulfur concentrations. 53 The figures shown here are for 4 atm total pressure, which corresponds to the NASA burner rig used for these studies. To test these calculations, quartz specimens were run in a burner rig under conditions corresponding to points (A) and (B) in Figures $5(a)$ and (b). Visual examination of the specimens suggested the higher sulfur fuel caused only limited corrosion, as shown in Figure 6. These coupons were also tested for water soluble silicon, which indicates the 
presence of sodium silicate. The coupons corroded in Jet $A$ fuel for only $1 \mathrm{hr}$ with $2 \mathrm{ppm} \mathrm{Na}$ had $0.16 \pm 0.10 \mathrm{mg} \mathrm{si} / \mathrm{cm}^{2}$, whereas the coupons corroded for $5 \mathrm{hrs}$ in No. 2 Diesel fuel with $2 \mathrm{ppm}$ Na had $0.003 \pm 0.003 \mathrm{mg} \mathrm{si} / \mathrm{cm}^{2}$. These data are consistent with the predictions.

It has been shown that corrosion occurs by dissolution of the $\mathrm{SiO}_{2}$. The conditions for dissolution are determined by the activity of $\mathrm{Na}_{2} \mathrm{O}$, which can be calculated for the particular condition. These general principles can be extended to other salt systems. In the case of $\mathrm{Na}_{2} \mathrm{CO}_{3}$, $\mathrm{p}\left(\mathrm{CO}_{2}\right)$ sets the activity of $\mathrm{Na}_{2} \mathrm{O}$ :

$$
\mathrm{Na}_{2} \mathrm{CO}_{3}(1)=\mathrm{Na}_{2} \mathrm{O}(\mathrm{s})+\mathrm{CO}_{2}(\mathrm{~g})
$$

$\mathrm{Na}_{2} \mathrm{CO}_{3}$ tends to dissociate more than $\mathrm{Na}_{2} \mathrm{SO}_{4}$ and hence is a more basic molten salt. Indeed, it has been shown that the $\mathrm{Na}_{2} \mathrm{CO}_{3}$ tends to attack silica much more readily than $\mathrm{Na}_{2} \mathrm{SO}_{4} \cdot 45$ In the case of $\mathrm{NaCl}$ and water vapor, $\mathrm{Na}_{2} \mathrm{O}$ can form by the following reaction 89 :

$$
2 \mathrm{NaCl}(\mathrm{v})+\mathrm{H}_{2} \mathrm{O}(\mathrm{v})=\mathrm{Na}_{2} \mathrm{O}(\mathrm{s})+2 \mathrm{HCl}(\mathrm{g})
$$

In this case $a\left(\mathrm{Na}_{2} \mathrm{O}\right)$ would be set by the vapor pressures of the other three species.

It should be noted that other compounds in the environment and/or the material under consideration may influence the activity of $\mathrm{Na}_{2} \mathrm{O}$. This is well documented for 
metallic alloys. ${ }^{2}$ In the case of silicon carbide, a common additive is carbon. It has been shown that carbon can drive a melt basic 53 by the following reactions:

$$
\begin{aligned}
& \mathrm{Na}_{2} \mathrm{SO}_{4}(\mathrm{I})+2 \mathrm{C}=\mathrm{Na}_{2} \mathrm{~S}+2 \mathrm{CO}_{2} \\
& \mathrm{Na}_{2} \mathrm{~S}+3 \mathrm{Na}_{2} \mathrm{SO}_{4}=4 \mathrm{Na}_{2} \mathrm{O}+4 \mathrm{SO}_{2}
\end{aligned}
$$

This fact explains the more extensive corrosion of SiC containing carbon additives compared to SiC with other additives. Additional deposits can also alter the activity of $\mathrm{Na}_{2} \mathrm{O}$. As mentioned, vanadium oxides are a common fuel impurity and can deposit as sodium vanadate along with sodium sulfate. This may decrease $a\left(\mathrm{Na}_{2} \mathrm{O}\right)$ thus creat a more acidic deposit. ${ }^{2}$

Another important variable is the potential of gaseous oxygen at the melt/ceramic interface. In a deep melt, this potential can be quite low. It is well known that SiC and $\mathrm{Si}_{3} \mathrm{~N}_{4}$ undergo a transistion from passive oxidation (to $\mathrm{SiO}_{2}$ ) to active oxidation (to Sio) at sufficiently low oxygen potentials. 21 Therefore some investigators 21,75 have proposed that the corrosion mechanism in melts with low oxygen potentials involves active oxidation:

$$
\operatorname{SiC}(\mathrm{s})+\mathrm{O}_{2}(\mathrm{~g})=\operatorname{sio}(\mathrm{g})+\mathrm{CO}(\mathrm{g})
$$

This mechanism can explain excessive bubbling and consumption of the material in a deep melt.

Another mechanism is based on the $\mathrm{Na}$ present in these salts. It is well known that $\mathrm{Na}$ can induce devitrification 
in amorphous $\mathrm{SiO}_{2} \cdot{ }^{46}$ The resultant volume change can cause cracking and a breakdown of the protective $\mathrm{SiO}_{2}$ layer. Thus even acidic salts may lead to degradation of $\mathrm{SiO}_{2}$ protected ceramics via this mechanism. 39-41,52

The discussion so far has centered on fairly simple sodium containing salt deposits. In the case of a coal slag, the situation becomes much more complex. Slags are composed of roughly eight different oxides and $\mathrm{a}\left(\mathrm{Na}_{2} \mathrm{O}\right)$ can therefore no longer be used as a simple index of basicity. A relative measure of basicity is given by the ratio of basic oxides to acidic oxides. Table $\mathrm{V}$ gives a typical basic and acidic coal slag composition. 62 The possible corrosion mechanisms by a basic coal slag have recently been discussed. 63 The three mechanisms disscussed are passivation via $\mathrm{SiO}_{2}$ formation, dissolution of $\mathrm{SiO}_{2}$ by the basic slag, and formation of localized Fe-Ni-silicides. The first two mechanisms are similar to those discussed for corrosion by $\mathrm{Na}_{2} \mathrm{SO}_{4}$. The last mechanism occurs in a deep melt $(\geq 100 \mu \mathrm{m})$ where the oxygen potential is low enough that the silicon material does not oxidize and reactions such as the following occur:

$$
13 \mathrm{SiC}+5 \mathrm{Fe}(\mathrm{slag} \text { matrix })=\mathrm{Fe}_{5} \mathrm{Si}_{13}+13 \mathrm{C}
$$

Thus the presence of transition metal oxides in slags can lead to some important corrosion mechanism differences between slag induced corrosion and $\mathrm{Na}_{2} \mathrm{SO}_{4}$ induced corrosion. 


\section{Reaction Kinetics}

An understanding of a corrosion mechanism includes more than just the major chemical reactions. It also includes a knowledge of the reaction rates and rate controlling steps. For heat engine applications, these are best studied through carefully controlled laboratory experiments using thin salt films. The thin salt films are airbrushed from a saturated aqueous solution onto a ceramic coupon, and the coated coupon is placed in a furnace with a well defined gas environment. The reaction can be followed with several techniques. The most common is thermogravimetric analysis, where the weight change is continuously monitored as a function of time. Another technique is chemical analysis of the corrosion scales at various time intervals. The corrosion products from silicon based ceramics are particularly well suited for chemical analysis because they consist of sodium silicate and sodium sulfate, which are both water soluble, and silica, which is only HF soluble. When a clear distinction occurs between these two phases, the authors have found the technique outlined in Figure 7 to provide useful information. 45

In addition to following the chemical reaction with thermogravimetric and chemical analysis techniques, the 
morphology of the reaction products can be examined after various reaction times. Product layers can be selectively removed by water or $\mathrm{HF}$ leaches and the resultant exposed surfaces examined. Polished cross sections show the distribution of elements throughout the product layers. Non-aqueous lubricants and solvents must be used to preserve the water soluble phases.

Consider first the chemical kinetics of the corrosion by sodium carbonate. 46,51 As mentioned, this is a basic molten salt which readily dissolves the protective oxide layer. Figures $8(a)$ and $8(b)$ are thermogravimetric and chemical analysis kinetic curves, respectively, for the reaction of SASC $(B, C)$ with $\mathrm{Na}_{2} \mathrm{CO}_{3}$ at $1000^{\circ} \mathrm{C}$. There are three distinct reaction stages. Stage $I$ is characterized by a rapid weight loss for the first few minutes of reaction and is attributed to the coupled oxidation of SiC and dissolution of the resultant oxide:

$$
\begin{aligned}
\mathrm{SiC}(\mathrm{s})+3 / 2 \mathrm{O}_{2}(\mathrm{~g}) & =\mathrm{SiO}_{2}(\mathrm{~s})+\mathrm{CO}(\mathrm{g}) \\
\mathrm{xSiO}_{2}(\mathrm{~s})+\mathrm{Na}_{2} \mathrm{CO}_{3}(1) & =\mathrm{Na}_{2} \mathrm{O} \cdot \mathrm{x}\left(\mathrm{SiO}_{2}\right)(1)+\mathrm{CO}_{2}(\mathrm{~g})
\end{aligned}
$$

If $x$ is taken as 1 and the amount of $\mathrm{Na}_{2} \mathrm{CO}_{3}$ taken to be the typical loading of $2.5 \mathrm{mg} / \mathrm{cm}^{2}$, a weight loss can be estimated. This was quite close to that measured. A number of different types of $\mathrm{Si}, \mathrm{SiC}$, and $\mathrm{Si}_{3} \mathrm{~N}_{4}$ ceramics have been 
examined. Each exhibited a Stage I weight loss close to that calculated from reactions (14) and (15), and analogous reactions for $\mathrm{Si}$ and $\mathrm{Si}_{3} \mathrm{~N}_{4} \cdot 51$

Next consider reaction stage II. This is a period of slow weight gain. In Figure $8(a)$ this appears somewhat parabolic, suggesting mass transport is rate limiting. Examination of Figure $8(\mathrm{~b})$ suggests that Stage II is characterized by the formation of $\mathrm{SiO}_{2}$. However, this rate of growth is substantially faster than simple oxidation. Microstructural observations indicate that this $\mathrm{SiO}_{2}$ does not form as a dense, protective layer, but rather in non-protective patches. This accounts for the rapid growth rates. It may also be that small amounts of $\mathrm{Na}$ dope the $\mathrm{SiO}_{2}$, leading to more rapid transport rates. 28,29,39-41 As time progresses, this lower layer becomes dense and seals off the Sic from further reaction in Stage III. Figure 9 is a polished cross section which shows this layered structure. Mayer and Riley 28 have focused their attention on the time required to reach stage III for various temperatures and amounts of $\mathrm{Na}_{2} \mathrm{CO}_{3}$. They have found a correlation between the point at which the reaction terminates and a $\mathrm{Na}_{2} \mathrm{O}-$ to- $\mathrm{SiO}_{2}$ ratio close to the liquidus (Figure 3 ).

Figure 10 shows a thermogravimetric curve for the reaction of $\operatorname{SSN}\left(\mathrm{Y}_{2} \mathrm{O}_{3}\right)$ and $\mathrm{Na}_{2} \mathrm{CO}_{3}$. As discussed, Stage $I$ is 
essentially the same for all types of $\mathrm{SiC}$ and $\mathrm{Si}_{3} \mathrm{~N}_{4}$. However, note that Stage II for $\operatorname{SSN}\left(\mathrm{Y}_{2} \mathrm{O}_{3}\right)$ is substantially slower than Stage II for $\operatorname{SASC}(B, C)$. A variety of SiC and $\mathrm{Si}_{3} \mathrm{~N}_{4}$ ceramics were examined and it was found that both the rate and extent of Stage II is dependent on the particular ceramic and/or additive. The generally slower rates for $\mathrm{Si}_{3} \mathrm{~N}_{4}$ are attributed to either hindered nitrogen escape through the product layers and/or the possibility of the formation of a more protective $\mathrm{Si}_{2} \mathrm{O}_{2} \mathrm{~N}$ layer. 51 The differences between the various types of $\mathrm{Si}_{3} \mathrm{~N}_{4}$ are attributed to the migration of the additives into the corrosion layer which alters its transport properties.

The $\mathrm{Na}_{2} \mathrm{CO}_{3}$ corrosion kinetics provide a good basis for examining $\mathrm{Na}_{2} \mathrm{SO}_{4}$ corrosion. As mentioned, this is a more acidic molten salt and will not readily dissolve $\mathrm{SiO}_{2}$. Figure 11 shows thermogravimetric data for HIP RBSN + $\mathrm{Na}_{2} \mathrm{SO}_{4} / \mathrm{O}_{2}$. Without an overpressure of $\mathrm{p}\left(\mathrm{SO}_{3}\right)$, the a $\left(\mathrm{Na}_{2} \mathrm{O}\right)$ would be expected to vary. Electrochemical measurements show that in a $\mathrm{Na}_{2} \mathrm{SO}_{4} / \mathrm{O}_{2}$ system $53, \mathrm{a}\left(\mathrm{Na}_{2} \mathrm{O}\right)$ varies from $5.6 \times 10^{-14}$ to $1 \times 10^{-12}$. Referring to Figure 4 , this is a region where $\mathrm{SiO}_{2}$ would not be attacked. This explains the slow rates of reaction observed in Figure 11 . The slow weight loss is essentially all due to the vaporization of $\mathrm{Na}_{2} \mathrm{SO}_{4}$, which has the same rate of weight loss when applied to an inert platinum coupon. There is also a limited amount of 
dissolution, as some local regions of the melt are basic. This 30-40 hr period of weight loss was the same for all types of $\mathrm{Si}_{3} \mathrm{~N}_{4}$ examined.

Figure 12 shows thermogravimetric data for the reaction of $\operatorname{SASC}(\mathrm{B}, \mathrm{C})$ and $\mathrm{Na}_{2} \mathrm{SO}_{4} / \mathrm{O}_{2}$. This is substantially different than the reaction of $\mathrm{Si}_{3} \mathrm{~N}_{4}+\mathrm{Na}_{2} \mathrm{SO}_{4} / \mathrm{O}_{2}$. Indeed it has a similar appearance to the $\operatorname{SASC}(\mathrm{B}, \mathrm{C})$ or $\operatorname{SSN}\left(\mathrm{Y}_{2} \mathrm{O}_{3}\right)+\mathrm{Na}_{2} \mathrm{CO}_{3}$ reaction. This type of Sic contains about $3 \%$ excess carbon.90 It was pointed out in the previous section that carbon tends to drive $\mathrm{Na}_{2} \mathrm{SO}_{4}$ more basic. This accounts for the fact that Figure 13 shows kinetics similar to those observed for corrosion by $\mathrm{Na}_{2} \mathrm{CO}_{3}$.

Finally consider corrosion reactions by a strongly acidic salt-- $\mathrm{Na}_{2} \mathrm{SO}_{4} / 0.1 \% \mathrm{SO}_{3}-\mathrm{O}_{2}$. In this case the activity of $\mathrm{Na}_{2} \mathrm{O}$ should be constant at $5 \times 10^{-16}$, a value clearly in region of stability for $\mathrm{SiO}_{2}$. Table VI shows the chemical analysis results for $48 \mathrm{hrs}$ at $1000^{\circ} \mathrm{C}$. Note that no silicate was observed for all materials excepz $\operatorname{SASC}(B, C)$. The reasons for this are due to the effect of carbon on melt basicity. The carbon in the Sic creates locally basic conditions at the melt bottom, and the $\mathrm{SO}_{3}$ above the $\mathrm{Na}_{2} \mathrm{SO}_{4}$ deposit creates acidic conditions at the top of the melt. Thus dissolution occurs at the bottom of the melt and precipitation of $\mathrm{SiO}_{2}$ and regeneration of the $\mathrm{Na}_{2} \mathrm{SO}_{4}$ occurs at the top of the melt, as described in Figure 13. These 
self-sustaining reactions are termed "fluxing" and well known from the hot corrosion of metals. 2 Due to the fluxing mechanism, the microstructure shown in Figure 14 forms, which shows sodium silicate and sodium sulfate in a large portion of the product layer. This is indicated by the sodium and sulfur elemental maps, respectively.

The preceeding discussion of kinetics in molten salt corrosion has dealt with carefully controlled experiments with a thin film of salt. It is appropriate to comment on how these relate to actual cases of molten salt corrosion. The laboratory studies have shown that coupled oxidation-dissolution processes, such as reactions (12) and (13), are quite rapid. Thus the thick glassy layer observed in Figure 1 could form quite rapidiy. Under conditions where a basic molten salt is continuously deposited, extensive corrosion could occur. Under conditions where such a salt is only deposited for a limited amount of time, a healing layer of $\mathrm{SiO}_{2}$ may eventually develop. It is also important to note that carbon--either as an additive in the ceramic or deposited in the combustion situation--can drive a normally non-reactive acidic salt to a reactive basic salt.

Kinetic studies of reactions in deep melts are generally performed by withdrawing the specimens at various time intervals, removing the salt and products, and weighing the specimen.22,80-84 In general, partial removal of the 
products is obtained by treatment with water and total removal is obtained by treatment with an $\mathrm{HF}$ solution. Tessler et. al. 22 have observed $-30 \%$ weight loss of Sic in several hours and $-30 \%$ weight loss of $\mathrm{Si}_{3} \mathrm{~N}_{4}$ in $40-60 \mathrm{hrs}$. in a $\mathrm{Na}_{2} \mathrm{SO}_{4}$ melt. Note the more rapid dissolution of $\mathrm{SiC}$ follows the same trend as observed with the thin film studies. Shimada et. al.80-83 have examined the kinetics of corrosion of $\mathrm{SiC}$ and $\mathrm{Si}_{3} \mathrm{~N}_{4}$ in various sulfates and carbonates of lithium, sodium, and potassium. Under some conditions, they have found $\mathrm{SiC}$ to corrode more slowly than $\mathrm{Si}_{3} \mathrm{~N}_{4}$. This suggests that corrosion in deep melts is a complex function of the salt and ceramic and very likely parameters such as melt depth.

\section{Microstructural Changes}

The discussion thus far has centered on the chemical reactions involved in the corrosion of $\mathrm{SiC}$ and $\mathrm{Si}_{3} \mathrm{~N}_{4}$. The net effect of these reactions is consumption of the ceramic and it is important to understand the manner in which this occurs. Possible modes of attack are uniform surface recession or attack in localized regions. If the attack occurs in localized regions, it is important to determine the 
unique features of these regions. A knowledge of the attack mode should aid in understanding how corrosion effects the performance of the ceramic in service.

The corroded microstructure of the ceramic must be examined without the interference of the corrosion products. This can be done with two methods. One is by examination of a polished cross section, as shown in Figures 9 and 14 . Another is by cleanly removing the corrosion scale. In the case of SiC this can be done with HF, which dissolves the entire corrosion scale but does not attack the Sic. Figure 15 shows a sequence of the as-received SiC, the corroded SiC with the product layer, and the corroded Sic with the product layer cleanly removed.

As Figure 15 shows, molten salt corrosion of SiC leads to severe grain boundary attack and pitting. 49,50 This type of attack has been observed in oxidation 50,91 and corrosion by deep melts. 24 pitting is particularly important since the strength of a ceramic is often quite dependent on surface finish. Table VII lists the pit density corresponding to three different salt systems. In each case the specimen was corroded for $48 \mathrm{~h}$ at $1000^{\circ} \mathrm{C}$ with $2.5 \mathrm{mg} \mathrm{salt} / \mathrm{cm}^{2}$ applied as a film. These results correlate to the extent of reaction discussed in the chemistry section. The $\mathrm{Na}_{2} \mathrm{CO}_{3}$ case shows the least amount of pitting, since a healing $\mathrm{SiO}_{2}$ layer forms rapidly in this reaction. The $\mathrm{Na}_{2} \mathrm{SO}_{4} / \mathrm{SO}_{3}$ case is the fluxing 
situation and leads to the most extensive corrosion. This is reflected in the high pit density data.

The corrosion reactions (2) and (3) involve the release of gases. These escape through the scale as bubbles. These bubbles are 1-10 $\mu \mathrm{m}$ in diameter and are observed on all samples. Furthermore, they are often correlated with pits. Figure 16 shows a series of micrographs taken of the sodium silicate layer, the silica layer, and the $\operatorname{SASC}(B, C)$ substrate on a sample corroded with $\mathrm{Na}_{2} \mathrm{CO}_{3}$. Note the larger pits correlate directly with a bubble. It appears that when a gas bubble forms it exposes a fresh portion of SiC, which is susceptible for further attack. This is shown schematically in Figure 17 for $\mathrm{Na}_{2} \mathrm{CO}_{3}$ corrosion. Evidence suggests that a a similar mechanism is operative for $\mathrm{Na}_{2} \mathrm{SO}_{4} \cdot 50$

The question remains as to why bubbles form at some points in the melt leading to pits, whereas other areas exhibit limited bubble formation and pitting. The is quite apparent with pitting by $\mathrm{Na}_{2} \mathrm{CO}_{3}$. One possible explanation is a localized cell situation, analogous to aqueous pitting corrosion of metals. There are a number of parallels between the two cases. Both the aqueous media and the molten salt are conductors. Metals and SiC are also conductors. Furthermore the pitting morphology is similar in both cases. Pitting of metals occurs due to local regions of oxygen 
depletion (anodes) and excess oxygen (cathodes). It is quite likely that inhomogenieties in the salt film can create a similar situation in the sic case.

The attack morphology of $\mathrm{Si}_{3} \mathrm{~N}_{4}$ shows some interesting differences as compared to that of sic. The corrosion scale on $\mathrm{Si}_{3} \mathrm{~N}_{4}$ may also be removed with $\mathrm{HF}$, however $\mathrm{HF}$ can attack the grain boundary phase. Therefore a mild HF treatment 115 min, $10 \% \mathrm{HF}, 60^{\circ} \mathrm{C}$ ) must be used to obtain an accurate picture of the attack morphology. A sequence based on this treatment for $\mathrm{Si}_{3} \mathrm{~N}_{4}$ is shown in Figure 18.55 Note that the grain boundaries show substantial attack and pitting is of limited importance. This is consistent with the proposed electrochemical model for $\mathrm{SiC}$, since $\mathrm{Si}_{3} \mathrm{~N}_{4}$ is more insulating than sic. It is well known that the refractory oxide additives in $\mathrm{Si}_{3} \mathrm{~N}_{4}$ form a glassy grain boundary phase. This grain boundary phase is readily altered by the molten salt corrosion process. Figure 19 shows a polished cross section of $\mathrm{Si}_{3} \mathrm{~N}_{4}$. The important point is the yttrium map, which shows the outer 5-10 um of $\mathrm{Si}_{3} \mathrm{~N}_{4}$ is depleted in yttrium, which has migrated into the corrosion scale. This migration of yttrium has been observed in simple oxidation 92 and in corrosion by several investigators.39-41,51,52 In addition to this the corrodents -- $\mathrm{Na}$ and $\mathrm{S}$-- penetrate into the ceramic, very likely along grain boundaries. This was shown with some earlier electron microprobe measurements 22 and has 
been shown recently with Secondary Ion Mass Spectrometry (SIMS). 55 These SIMS results are shown in Figure 20. Note the $\mathrm{Y}$ depletion zone and the high levels of $\mathrm{Na}$ well into the sample. Even sulfur shows some limited penetration. In summary, molten salt corrosion causes some dramatic microstructural effects on the microstructure of SiC and $\mathrm{Si}_{3} \mathrm{~N}_{4}$. In the case of $\mathrm{SiC}$ this effect is primarily pitting. In the case of $\mathrm{Si}_{3} \mathrm{~N}_{4}$ this is primarily grain boundary attack. Coal slag corrosion produces complex microstructural changes, which are quite sensitive to slag chemistry and the specific ceramic. As mentioned, in some cases metal silicides form, which lead to surface pits.62,64,66 In other cases slag penetration into the ceramic is the dominant mode of attack, particularly with $\mathrm{Si}_{3} \mathrm{~N}_{4} \cdot{ }^{62}$ In still other cases, fairly even surface recession was observed.62 The next step is to assess how these microstructural changes affect the operation of these components in service.

\section{v. Strength Degradation}

As mentioned, the surface finish of a ceramic often has a major effect on its strength. Surface flaws may act as failure origins, leading to lower strengths compared to the 
same material with a uniform surface finish. The severe pitting observed in SiC would thus be expected to have an effect on the strength of this material.

Figure 21 shows the strength of $\operatorname{SASC}(B, C)$ for several different corrosion treatments. 49 Note that each corrosion treatment decreases the strength below the as-received value. Since the strengths of ceramics tend to show a substantial standard deviation, a Student's t-test was performed to determine if the observed strength reductions were significant. In all but the $\mathrm{Na}_{2} \mathrm{CO}_{3}$ case significant strength reductions were observed.

The relative strength reductions are consistent with the extent of chemical reaction for each of the laboratory tests. Although $\mathrm{Na}_{2} \mathrm{CO}_{3}$ reacts most readily with $\mathrm{SiC}$, the reaction was shown to be rapid, and a protective $\mathrm{SiO}_{2}$ layer forms before any extensive reaction and pitting can occur. The $\mathrm{Na}_{2} \mathrm{SO}_{4}$ reactions are somewhat more severe. It has been shown that $\mathrm{Na}_{2} \mathrm{SO}_{4} / \mathrm{SO}_{3}$ establishes a self-sustaining series of reactions and leads to extensive corrosion. This leads to severe pitting and the greatest strength reduction. The $\mathrm{Na}_{2} \mathrm{SO}_{4} / \mathrm{O}_{2}$ system appears to lie between the $\mathrm{Na}_{2} \mathrm{CO}_{3}$ case and the $\mathrm{Na}_{2} \mathrm{SO}_{4} / \mathrm{SO}_{3}$ case.

Other types of SiC were also tested in the burner rig. The resultant strength degradations are shown in Figure 22.55 
These types of Sic are described in detail in Table II. The greatest strength degradation is for RBSC which may be due to the free $\mathrm{Si}$ phase in this material, which is readily attacked by the molten salt. The common behavior of all types of SiC confirms that corrosion of SiC is due to the dissolution of the $\mathrm{SiO}_{2}$ layer by basic molten salts and the tendency of SiC to pit.

In order to further understand this strength degradation the fracture origins of numerous specimens were examined. In nearly all cases these were corrosion pits at the surface. Figures 23 and 24 show some representative fracture origins for $\operatorname{SASC}(B, C)$ tested in the furnace and burner rig, respectively. Note the deep pitting and grain boundary attack.

From fracture mechanics the fracture stress $\left(\sigma_{f}\right)$ is controlled by an idealized flaw as follows:

$$
\sigma_{\mathrm{f}}=\mathrm{z} / \mathrm{Y} \mathrm{K}_{\mathrm{IC}} /(\mathrm{a})^{1 / 2}
$$

Here $\mathrm{Z}$ is the flaw shape parameter, $\mathrm{Y}$ is a geometric factor, and $K_{I C}$ is the fracture toughness. The measurement (a) is the depth of an atomically sharp crack. Although corrosion pits are not strictly atomically sharp cracks, a plot of $\sigma_{f}$ vs $1 /(a)^{1 / 2}$ (Figure 25 ) gives a roughly linear dependence with a slope close to that observed from previous fracture toughness measurements. 49 This verifies that corrosion pit depth does indeed control strength. 
As discussed in the previous section, corrosion of $\mathrm{Si}_{3} \mathrm{~N}_{4}$ by molten salts leads to a different attack morphology that is dominated by grain boundary attack. It should also be noted that some types of $\mathrm{Si}_{3} \mathrm{~N}_{4}$ show a strength decrease due to softening of the glassy grain boundary phase at elevated temperatures. In examining these types of materials for corrosion induced strength degradation, the effect of strength degradation from a simple heat treatment must be separated from the effect of the molten salt.

Figure 26 shows the room temperature strengths for two types of sintered $\mathrm{Si}_{3} \mathrm{~N}_{4} \cdot 54$ The material with $\mathrm{Y}_{2} \mathrm{O}_{3}$ and $\mathrm{Al}_{2} \mathrm{O}_{3}$ shows a strength degradation from a simple $1000^{\circ} \mathrm{C}$ oxidation and a further strength degradation from a corrosion treatment. The student's t-test shows that both are significant. The material with $\mathrm{Y}_{2} \mathrm{O}_{3}$ shows a only a limited strength degradation from a $1000^{\circ} \mathrm{C}$ heat treatment, which is not statistically significant. However, it does show a significant strength reduction from the corrosion treatment.

Figure 27 shows a typical fracture origin for a corroded $\mathrm{Si}_{3} \mathrm{~N}_{4}$ sample. Although failure occurred near the surface, it was not associated with a deep pit, as in the sic case. It may be that attack of the grain boundary phase by the molten salt is the likely reason for the failure origin.

The results of high temperature strength testing are complex and point out the difficulties inherent to current 
types of $\mathrm{Si}_{3} \mathrm{~N}_{4}$. These are shown in Figures $28(\mathrm{a})$ and (b). Apparently the actual testing of these materials at elevated temperatures causes a strength decrease of magnitude close to that from the corrosion treatment. In summary, molten salt corrosion decreases the room temperature strengths of $\mathrm{Si}_{3} \mathrm{~N}_{4}$. However, high temperature strengths of these materials are less than the room temperature strengths regardless of their exposure.

This discussion has centered on strength degradation due to thin film and burner corrosion exposures. However deep melts cause similar strength reductions. $23,24,43,44,82,83$ Bourne and Tressler have shown an increase in critical flaw size and in most cases a decrease in fracture toughness due to molten exposure of $\mathrm{Si}_{3} \mathrm{~N}_{4} \cdot 23$ sato et. al.83 have also observed large increases in flaw sizes in $\mathrm{Si}_{3} \mathrm{~N}_{4}$ due to $\mathrm{K}_{2} \mathrm{CO}_{3}$ and $\mathrm{K}_{2} \mathrm{SO}_{4}$ deep melt exposure.

The information presented so far deals with the simple fast fracture strength of $\mathrm{SiC}$ and $\mathrm{Si}_{3} \mathrm{~N}_{4}$. To fully understand the effects of molten salt corrosion on these materials, time dependent mechanical properties must be considered as well. Loaded C-ring specimens of $\operatorname{SASC}(B, C)$ show shorter time to failure in a $\mathrm{NaCl}$ containing environment than a pure oxidizing environment. 76 Recent studies on have shown 
enhanced slow crack growth in both $\mathrm{SiC}$ and $\mathrm{Si}_{3} \mathrm{~N}_{4} \cdot 37,57$ This is attributed to the formation of a low melting silicate at the crack tip, creating less resistance to crack propogation. There is a good deal of information on the effects of coal slags on strengths of various ceramics.59-68 The extent of strength degradation appears to be quite dependent on the type of ceramic and the slag and it is difficult to identify any general trends. As mentioned, in an acidic slag only limited dissolution occurs and either pitting or slag penetration may lead to strength degradation. Basic slags lead to rapid rates of material consumption and may also exhibit pitting. In general wherever pitting was observed, strength degradations were also observed.

\section{Possible Solutions}

There are several possible solutions to the hot corrosion problem for silicon base ceramics. Either the salt deposit and/or the protective silica scale can be modified. The salt deposit can be modified by creating more acidic conditions. Figure 5(b) shows that a higher sulfur fuel can create a more acidic salt and limit corrosion. However, in practice this may not be feasible. There are other 
considerations which may preclude the use of a higher sulfur fuel. Furthermore, even if the overall conditions are acidic, locally basic regions may occur within the melt. The second approach is to modify the protective silica layer. Federer ${ }^{75}$ has suggested adding $\mathrm{Al}_{2} \mathrm{O}_{3}$ to produce $\mathrm{Na}_{2} \mathrm{O} \cdot \mathrm{SiO}_{2} \cdot \mathrm{Al}_{2} \mathrm{O}_{3}$ scales that are less susceptible to liquid formation. The next step beyond modification of the $\mathrm{SiO}_{2}$ scale is the application of an additional protective coating. Recent work at Solar Turbines, Inc. 93 has shown that a plasma sprayed mullite coating provides a promising protective layer for both heat exchanger tubes and heat engine components. Mullite shows a good match of thermal expansion with SiC, and the stochiometric $2\left(\mathrm{SiO}_{2}\right) \cdot 3\left(\mathrm{Al}_{2} \mathrm{O}_{3}\right)$ compound with no excess $\mathrm{SiO}_{2}$ shows good corrosion resistance. One difficulty with these coatings is their porosity. However if thicker layers are applied and/or the porosity is closed off, minimal salt penetration occurs. Some results ${ }^{94}$ are shown in Figure 29. The coated samples show $\mathrm{Na}_{2} \mathrm{SO}_{4}$ deposition but no silicate formation or attack (Figure $29(\mathrm{a})$ ) for a $20 \mathrm{hr}$ exposure. The uncoated samples exhibit the typical massive sodium silicate products discussed previously (Figure 1 and $29(\mathrm{~b})$ ). 


\section{Conclusions}

The $\mathrm{Na}_{2} \mathrm{SO}_{4}$ induced corrosion of silicon based ceramics has been discussed. The key reactant is $\mathrm{Na}_{2} \mathrm{O}$ which can be derived from a number of salt deposits. This reacts with the $\mathrm{SiO}_{2}$ scale and forms liquid $\mathrm{Na}_{2} \mathrm{O} \cdot \mathrm{x}\left(\mathrm{SiO}_{2}\right)$, which is not protective, and thus the ceramic is exposed to extensive attack. The dissolution reaction is controlled by a

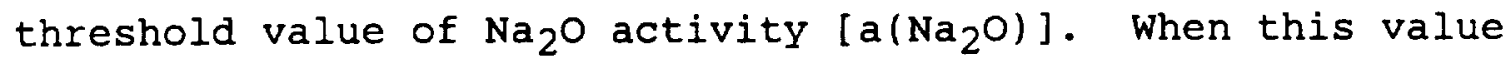
is greater than a certain level (i.e. basic molten salt), the dissolution reaction readily occurs. In some combustion conditions this $a\left(\mathrm{Na}_{2} \mathrm{O}\right)$ can be calculated and the possibility of corrosion predicted. It should be noted, however, that $\mathrm{a}\left(\mathrm{Na}_{2} \mathrm{O}\right)$ often shows a complex dependence on gas atmosphere and additives in the ceramic material. Carbon, in particular, tends to drive $a\left(\mathrm{Na}_{2} \mathrm{O}\right)$ to higher levels. In complex systems such as coal slags, silicon based ceramics show the same rapid dissolution if the system is sufficiently basic.

The kinetics of these corrosion processes are complex, involving several reaction steps. For thin films of $\mathrm{Na}_{2} \mathrm{CO}_{3}$ and $\mathrm{Na}_{2} \mathrm{SO}_{4}$, the reaction sequence consists of rapid dissolution and eventual formation of a protective $\mathrm{SiO}_{2}$ layer when the available $\mathrm{Na}_{2} \mathrm{O}$ is consumed. In a combustion situation, where there is a continuous source of $\mathrm{Na}_{2} \mathrm{O}$, this 
silica layer may never form and the ceramic may dissolve entirely in the salt.

The precise type of attack is important in assessing how the materials respond to corrosion in service. Molten salts dramatically pit SiC. The source of these pits are attributed to bubble formation during the reaction process and a possible electrochemical reaction scheme. The corrosion process in $\mathrm{Si}_{3} \mathrm{~N}_{4}$ leads to extensive grain boundary attack, an additive depletion layer, and $\mathrm{Na}$ and $\mathrm{S}$ penetration.

These microstructural changes lead to changes in the mechanical properties of the ceramic. Sic shows strength decreases which are directly attributable to the corrosion pits. In general, $\mathrm{Si}_{3} \mathrm{~N}_{4}$ shows a room temperature strength decrease due to molten salt corrosion. However, at higher temperatures the effect is not as clear due to strength losses intrinsic to many types of $\mathrm{Si}_{3} \mathrm{~N}_{4}$. Time dependent mechanical properties are also degraded by corrosion. In the case of slow crack growth, the solid oxide at the crack tip becomes a liquid due to the interaction with $\mathrm{Na}$ and there is less resistance to crack growth.

For coal slags, the microstructural changes are in the form of pits associated with metal silicide formation, slag penetration, and/or surface recession. In general, when pits form, a strength degradation occurs. 
Solutions to the hot corrosion problem for silicon based ceramics center on creating a less basic salt deposit and/or altering the protective oxide scale. Currently it appears application of a dense refractory oxide protective coating is the most effective. 


\section{REFERENCES}

1. F.J. Kohl, C.A. Stearns, and G.C. Fryburg, Sodium Sulfate: Vaporization and Role in Corrosive Flames, Metal-Slag-Gas Reactions and Processes, (Z.A. Foroulis and W.W. Smeltzer, eds.) The Electrochemical Society, Pennington, NJ, 1975, p. 649.

2. F.S. Pettit and C.S. Giggins, Hot Corrosion, Superalloys II, (C.T. Sims, N.S. Stoloff, and W.C. Hage1, eds.) Wiley \& Sons, New York, 1987, p.327.

3. E. Raask, Mineral Impurities in Coal Combustion, Hemisphere Publishing Company, Washington, 1985.

4. A.D. Russel1, C.E. Smeltzer, and M.E. Ward, "Waste Heat Recuperation for Aluminum Furnaces," GRI-81/0187, Solar Turbines Inc., San Diego, CA, 1983.

5. J.E. Bennett, F.J. Kohl, C.A. Stearns, G.C. Fryburg, and J.A. Burkhart, "Preliminary Evaluation of the Role of $\mathrm{K}_{2} \mathrm{~S}$ in MHD Hot Stream seed Recovery," NASA TM-79114, DOE/NASA/2674-79/1, 1979 .

6. H.S. Hsu, J.H. DeVan, and M. Howell, Corrosion of Iron in Molten Carbonates at $650^{\circ} \mathrm{C}$, Fundamental Aspects of High Temperature Corrosion--II, The Electrochemical Society, Pennington, NJ, 1986, p. 86.

7. G.K. Watson, T.J. Moore, and M.L. Millard, "Effect of Hot Isostatic Pressing on Reaction-Bonded Silicon Nitride," J. Am. Ceram. Soc., 67[10]: C-208 (1984).

8. F.H. Horn, "Screw Dislocations, Etch Figures, and Holes," Philos. Mag., 43: 1210 (1952).

9. J.W. Faust, The Etching of Silicon Carbide, silicon Carbide: A High Temperature Semiconductor, (J.R. $O$ 'Connor and J. Smiltens, eds.) Pergamon Press, New York, 1959, p. 403.

10. S. Amelinckx, G. Strumane, and W.W. Webb, "Dislocations in Silicon Carbide," J.Appl. Phys., 31[8]: 1359 (1960).

11. T. Gabor and R. Stickler, "Chemical Etching studies and Transmission Electron Microscopy of Silicon Carbide," Nature, 199[489]: 1054 (1963). 
12. T. Gabor and V.J. Jennings, "The Effect of Stirring on the Etching Characteristics of Silicon Carbide," Electrochem. Technol., 3: 31 (1965).

13. J,W. Eaust, Jr, and H.M. Liaw, Tables of Etchants for SiC, Silicon Carbide - 1973, (R.C. Marshal1, J.W. Faust Jr., and C.E. Ryan, eds.) University of South Carolina Press, Columbia, SC, 1974, p. 657.

14. S.C. Singhal, Corrosion Behavior of Silicon Nitride and Silicon Carbide in Turbine Atmospheres, Proceedings of the 1972 Tri-Service Conference on Corrosion, MCIC-73-19, Metals and Ceramics Information Center, Battelle Labs, Columbus, $\mathrm{OH}, 1973, \mathrm{p} .245$.

15. S.C. Singhal, Corrosion-Resistant structural Ceramic Materials for Gas Turbines, Gas Turbine Materials in the Marine Environment 1974, MCIC-75-27, (J.W. Fairbanks and I. Machlin, eds.) Metals and Ceramics Information Center, Battelle Labs, Columbus, $\mathrm{OH}, 1974$, p. 311 .

16. R.H. Arendt and M.J. Curran, Corrosion of Dense Silicon Carbide in Basic Molten Salt Solutions, Metal-Slag-Gas Reactions and Processes, (Z.A. Foroulis and W.W. Smeltzer, eds.) The Electrochemical Society. Pennington, NJ, 1975, p. 636 .

17. J. Schlichting, "Heisskorrosionsverhalten von SiC und $\mathrm{Si}_{3} \mathrm{~N}_{4}$ im Brennergas," Werkst. Korros., 26 [10]: 753 (1975).

18. J. Schlichting, Oxidation and Hot Corrosion Behavior of $\mathrm{Si}_{3} \mathrm{~N}_{4}$ and SiAlON, Nitrogen Ceramics, (F.L. Riley, ed.) Noordhoff, Leyden, 1977, p. 627.

19. J. Schlichting, "Oxidation Kinetic of Silicon Ceramic from the Point of Refractory Materials Resistant Against Hot Corrosion," Rev. Int. Hautes Temp. Refract., 16: 67 (1979).

20. J. Schlichting, New Results on Hot Corrosion of Silicon Ceramics, High Temperature Corrosion of Metals and

Alloys, Japan Institute of Metals, Tokyo, Japan, 1983, p. 607 . 
21. D.W. Mckee and D. Chatterji, "Corrosion of Silicon Carbide in Gases and Alkaline Melts," J. Am. Ceram. Soc., 59[9-10]: 441 (1976).

22. R.E. Tressler, M.D. Meiser, and T. Yonushonis, "Molten Salt Corrosion of $\mathrm{SiC}$ and $\mathrm{Si}_{3} \mathrm{~N}_{4}$ Ceramics," J. Am. Ceram. Soc., 59 [5-6]: 278 (1976).

23. W.C. Bourne and R.E. Tressler, Alteration of Flaw Sizes and KIC's of $\mathrm{Si}_{3} \mathrm{~N}_{4}$ Ceramics by Molten Salt Exposure, Fracture Mechanics of Ceramics, Vol. 3, (R.C. Bradt, D.P.H. Hasselman, and F.F. Lange, eds.) Plenum Press, New York, 1978, p. 113.

24. W.C. Bourne and R.E. Tressler, "Molten Salt Degradation of $\mathrm{Si}_{3} \mathrm{~N}_{4}$ Ceramics," Am. Ceram. Soc. Bull., 59 [4]: 443 (1980).

25. E. Erdoes and H. Altorfer, Corrosion Behavior of Hot-Pressed and Reaction-Bonded Silicon Nitride in Condensed Phases, Materials and Coatings to Resist High Temperature Corrosion, (D.R. Holmes and A. Rahmel, eds.) Elsevier Applied Science Publishers, London, 1977, p. 161 .

26. C.T. Sims and J.E. Palko, Surface Stability of Ceramics Applied to Energy Conversion Systems, Proceedings of the Workshop on Ceramics for Advanced Heat Engines, CONF-770110, Dept. of Energy, Washington, D.C., 1977, p. 287 .

27. J.E. Palko, "A Review of Oxidation and Hot Corrosion of Silicon Based Ceramics," Report 77-GTD-55, General Electric, Schenectady, NY, 1977.

28. M.I. Mayer and F.L. Riley, "Sodium-Assisted Oxidation of Reaction-Bonded Silicon Nitride," J. Mater. Sci., 13: 1319 (1978).

29. M.I. Mayer and F.L. Riley, "Sodium Ion Assisted Oxidation of Reaction-Bonded Silicon Nitride," Proc. Br. Ceram. Soc, 26 : 251 (1978).

30. M. Levy and J.J. Falco, "Hot Corrosion of ReactionBonded $\mathrm{Si}_{3} \mathrm{~N}_{4}, "$ Am. Ceram. Soc. Bul1., 57[4]: 457 (1978). 
31. D.W. Richerson and T.M. Yonushonis, Environmental Effects on the Strength of Silicon-Nitride Materials, Proceedings of the DARPA/NAVSEA Ceramic Gas Turbine Demonstration Engine Program Review, MCIC-78-36, ( J.W. Fairbanks and R.W. Rice, eds.) Metals and Ceramics Information Center, Battelle Labs, Columbus, OH, 1977, p. 247 .

32. D.W. Richerson and K.M. Johansen, "Ceramic Gas Turbine Engine Demonstration Program," REPT-21-4410, Garrett Turbine Engine Co., Phoenix, AZ, 1982. (Avail. NTIS, AD-A117088).

33. S. Brooks and D.B. Meadowcroft, "The Corrosion of Silicon-Based Ceramics in Residual Fuel-oil-Fired Environment," Proc. Br. Ceram. Soc., 26: 237 (1978).

34. R.H. Barkalow and F.S. Pettit, Evaluation of Hot Corrosion Resistance of Candidate Ceramic Coatings for Industrial/Utility Gas Turbines, 4th Annual Conference on Materials for Coal Conversion and Utilization, CONF-791014, Dept. of Energy, Washington, D.C., 1979, P. II. 58 .

35. R.N. Katz, "Corrosion/Erosion Behavior of Silicon Nitride and Silicon Carbide Ceramics: Gas Turbine Experience," AMMRC-MS-79-2, Army Materials and Mechanics Research Center, Watertown, MA, 1979. (Avail. NTIS, $A D-A 076382$ ).

36. P.L. Cavallotti, U. Ducati, and P.C. Martinengo, Oxidation and Hot Corrosion Behavior of Sintered Nitrogen Ceramics, Ceramics for Turbine Engine Applications, AGARD-CP-276, AGARD, Neuilly-Sur-Seine, France, 1979. (Avail. NTIS, AD-A087594).

37. D.E. Schwab and D.M. Kotchick, "High Temperature Strength of Sintered $\alpha-S i C$ in Salt and oxidizing Environments," Am. Ceram. Soc. Bul1., 59[8]: 805 (1980).

38. J.C. Napier, "Manufacturing Methods for Ceramic Nozzle Section for Gas Powered APU'S," Report SR84-R-4692-64, Solar Turbines Incorporated, San Diego, CA, MaY 7, 1984.

39. J.R. Blachere and F.S. Pettit, "High-Temperature Corrosion of Ceramics," DOE/ER/10915-3, 1984. 
40. J.R. Blachere and F.S. Pettit, "High-Temperature Corrosion of Ceramics," DOE/ER/10915-4, 1984.

41. J.R. Blachere and F.S. Pettit, "High-Temperature Corrosion of Ceramics," Progress Report DOE/ER/45117-1, 1985 .

42. W.L. Fielder, "Oxidation and Hot Corrosion of Hot-Pressed $\mathrm{Si}_{3} \mathrm{~N}_{4}$ at $1000^{\circ} \mathrm{C}, "$ NASA TM-86977, 1985.

43. G.A. Gogotsi, Yu. G. Gogotsi, V.P. Zavada, and S.I. Sopenko, "Action of Salts on the Strength and Crack Resistance of Silicon Nitride Ceramics," Strength Mater. (Engl. Transl.), 16[11]: 1515 (1984).

44. G.A. Gogotsi, V.P. Zavada, and Yu. G. Gogotsi, "Strength Degradation of $\mathrm{Si}_{3} \mathrm{~N}_{4}-\mathrm{SiC}$-Based Ceramics in Salt Environments," Ceram. Int., 12[4]: 203 (1986).

45. N.S. Jacobson and J.L. Smialek, "Hot Corrosion of Sintered $\alpha-\operatorname{SiC}$ at $1000^{\circ} \mathrm{C}, " \mathrm{~J}$. Am. Ceram. SoC., 68[8]: 432 (1985).

46. N.S. Jacobson, "Kinetics and Mechanism of Corrosion of SiC by Molten Salts," J.Am. Ceram. Soc., 69[1]: 74 (1986).

47. N.S. Jacobson, C.A. Stearns, and J.L. Smialek, "Burner Rig Corrosion of $\mathrm{SiC}$ at $1000^{\circ} \mathrm{C}$, "Adv. Ceram. Mater." I [2]: $154(1986)$.

48. R. Browning, J. Smialek, and N. Jacobson, "Scanning Auger Microscopy of Corroded SiC," J. Mater. Sci, Lett., 5: 1122 (1986).

49. J.L. Smialek and N.S. Jacobson, "Mechanism of Strength Degradation for Hot Corrosion of $\alpha-S i C, " J$. Am. Ceram. Soc., 69[10]: 741 (1986).

50. N.S. Jacobson and J.L. Smialek, "Corrosion Pitting of SiC by Molten Salts," J. Electrochem. Soc., 133[12]: 2615 (1986).

51. D.S. Fox and N.S. Jacobson, "Molten-Salt Corrosion of Silicon Nitride: I, Sodium Carbonate," J.Am. Ceram. Soc., 7I[2]: 128 (1988).

52. N.S. Jacobson and D.S. Fox, "Molten-Salt Corrosion of Silicon Nitride: II, Sodium Sulfate," J. Am. Ceram. Soc., 71[2]: 139 (1988). 
53. N.S. Jacobson, "Sodium Sulfate: Deposition and Dissolution of Silica," to appear in oxid. Met., (1988).

54. D.S. Fox and J.L. Smialek, "Burner Rig Hot Corrosion of Ceramic Engine Materials," submitted to Adv. Ceram. Mater., (1988).

55. D.S. Fox and N.S. Jacobson, "The Effect of Hot Corrosion on the Microstructure and Strength of Silicon Nitride". in preparation.

56. N.J. Tighe, J. Sun, and R.M. Hu, "Corrosion Reactions in SiC Ceramics," Ceram. Eng. Sci. Proc, , 8 [7-8]: 805 (1987).

57. C.H. Henager, Jr, and R.H. Jones, "Environmental Effects on Slow Crack Growth in Silicon Nitride," Ceram. Eng. Sci. Proc., 9 [7-8]: (1988).

58. R. Nagarajan, "CVD Processes Leading to the Formation and Dissolution of Ceramic Coatings on Combustion Turbine Airfoils," Heat Transfer--Houston 1988, (S.B. Yilmaz, ed.) AIChE Symposium Series, 84[263]: 86 (1988).

59. M.K. Ferber and V.J. Tennery, "Evaluation of Tubular Ceramic Heat Exchanger Materials in Acidic Coal Ash from Coal-Oil-Mixture Combustion," ORNL/TM-7958, 1981.

60. M.K. Ferber and V.J. Tennery, "Evaluation of Tubular Ceramic Heat-Exchanger Materials in Basic Coal Ash from Coal-Oil-Mixture Combustion," ORNL/TM-8385, 1982.

61. M.K. Ferber, V.J. Tennery, and J.F. Willmering, "Exposure of Tubular Ceramic Heat Exchanger Materials to Refractory Coal Ash from Coal-Oil-Mixture Combustion," ORNL/TM-9052, 1984 .

62. P.F. Becher, "Strength Degradation in $\mathrm{SiC}$ and $\mathrm{Si}_{3} \mathrm{~N}_{4}$ Ceramics by Exposure to Coal Slags at High Temperatures," J. Mater. Sci., 19: 2805 (1984).

63. M.K. Ferber, J. ogle, V.J. Tennery, and T. Henson, "Characterization of Corrosion Mechanisms Occurring in a Sintered SiC Exposed to Basic Coal Slags," J.Am. Ceram. Soc., 68[4]: 191 (1985). 
64. M.K. Ferber, J. Ogle, and P.F. Becher, "Effect of Oxidizing and Coal-Slag Environments upon the Time-Dependent Strength Behaviour of a Sintered SiC," J. Mater. Sci., 21: 2678 (1986).

65. T.E. Easler and R.B. Poeppe1, "Corrosion of Ceramics in Heat Exchanger Applications," High Temperature Corrosion in Energy Systems, (M.F. Rothman, ed.), Metallurgical Society of AIME, Warrendale, PA, 1984, p.

66. T.E. Easler, "Corrosion Behavior and Mechanical Properties of Silicon Carbide Exposed to a Coal Gasification Environment," ANL/FE-84-21, Argonne National Laboratory, (1985).

67. T.E. Easler, "Effects of Coal Gasification Environments on Corrosion Behavior and Mechanical Properties of Siliconized Silicon Carbide," ANL/FE-85-6, Argonne National Laboratory, 1985.

68. T.E. Easler, "Comparison of Results of 200- and 500-h Exposures of Silicon Carbide to a slagging Coal Gasification Environment," ANL/FE-85-13, Argonne National Laboratory, 1986.

69. E. Buchner and O. Rubisch, Corrosion Behavior of Silicon Carbide Heating Elements, Silicon Carbide 1973, (R.C. Marshall, J.W. Faust Jr., and C.E. Ryan, eds.) University of South Carolina Press, Columbia, SC, 1974, p. 428 .

70. G.W. Weber and V.J. Tennery, "Materials Analyses of Ceramics for Glass Furnace Recuperators," ORNL/TM-6970, (1979).

71. G.C. Wei and C.L. White, "High Temperature Behavior of Pressureless-Sintered $\mathrm{SiC}$ in a steel Soaking Pit Environment," Am. Ceram. Soc. Bull., 63[7]: 890 (1984).

72. J.I. Federer, T.N. Tiegs, D.M. Kotchick, and D. Petrak, "Analysis of Candidate Silicon Carbide Recuperator Materials Exposed to Industrial Furnace Environments," ORNL/TM-9677, (1985).

73. J.I. Federer and P.J. Jones, "Oxidation/Corrosion of Metallic and Ceramic Materials in an Aluminum Remelt Furnace," ORNL/TM-9741, 1985. 
74. J.I. Federer, J.M. Robbins, P.J. Jones, and C. Hamby, Jr. "Corrosion of SiC Ceramics in Synthetic Combustion Atmospheres Containing Halides," ORNL-6258, 1985.

75. J.I. Federer, "Corrosion of $\mathrm{SiC}$ Ceramics by $\mathrm{Na}_{2} \mathrm{SO}_{4}$," Adv. Ceram. Mater., 3[1]: 56 (1988).

76. J.I. Federer, "Stress-Corrosion of SiC in an Oxidizing Atmosphere Containing NaCl," Adv. Ceram. Mater., 3[3]: 293 (1988).

77. J.I. Federer, "Corrosion of Materials by High-Temperature Industrial Combustion Environments - A. Summary," ORNL/TM-9903, (1986).

78. J. Van Ackeren and T. Stillwagon, Corrosion of Silicon Carbide Tubes in Industrial Flue Gas Streams, Corrosion of Ceramic Materials Workshop: Proceedings, (B.K.

Kennedy, ed.) Center for Advanced Materials, Pennsylvania State University, University Park, PA, 1987, p. 43.

79. J.W. Cree and M.F. Amateau, "Mechanical Behavior of SiC Exposed to Molten Lithium and Lithium Salts," Ceram. Eng. Sci. Proc., 8[7-8]: 812 (1987).

80. T. Sato, Y. Kanno, and M. Shimada, "Corrosion of SiC, $\mathrm{Si}_{3} \mathrm{~N}_{4}$, and $\mathrm{AIN}$ in Molten $\mathrm{K}_{2} \mathrm{SO}_{4}-\mathrm{K}_{2} \mathrm{CO}_{3}$ Salts, "Int. J. High Technol. Ceram., 2[4]: 279 (1986).

81. T. Sato, Y. Kanno, T. Endo, and M. Shimada, "Corrosion of $\mathrm{Si}_{3} \mathrm{~N}_{4}$ in Molten Alkali sulfate and Carbonate," Adv. Ceram. Mater., 2[3A]: 228 (1987).

82. M. Shimada, T. Sato, and T. Endo, High Temperature Corrosion and Degradation in Strength of Silicon Nitride Based Ceramics by Alkali Sulfates and Carbonates Melts, High Temperature Materials Chemistry IV, (Z.A. Munir, D. Cubicciotti, and H. Tagawa, eds.) The Electrochemical Society, Pennington, NJ, 1987.

83. T. Sato, Y. Koike, T. Endo, and M. Shimada, "Corrosion and strength Degradation of $\mathrm{Si}_{3} \mathrm{~N}_{4}$ and sialons in $\mathrm{K}_{2} \mathrm{CO}_{3}$ and $\mathrm{K}_{2} \mathrm{SO}_{4}$ Melts," J. Mater. Sci., 23: 1405 (1988). 
84. K. Tajiri, T. Nishio, T. Asahina, and M. Kosaka, Corrosion of Hot-Pressed Silicon Nitride in Alkali Carbonate Melts, Joint International Symposium on Molten Salts, (G. Mamantov, M. Blander, C. Hussey, C. Mamantov. M.L. Saboungi, and J. Wilkes, eds.) The Electrochemical Society, Pennington, NJ, 1987, p. 717.

85. S. Gordon and B.J. McBride, "Computer Program for Calculation of Complex Chemical Equilibrium Compositions, Rocket Performance, Incident and Reflected Shocks, and Chapman-Jouget Detonations", NASA SP-273, 1976.

86. W.D. Kingery, H.K. Bowen, and D.R. Uhlmann, Introduction to Ceramics, Wiley, New York, 1976, p. 359.

87. A.D. Pelton, C.W. Bale, and W.T. Thompson, "FACT (Facility for the Analysis of Chemical Thermodynamics) A Computerized Canadian Thermodynamic Data Treatment Center," Applications of Phase Diagrams in Metallurgy and Ceramics, NBS-SP-496, Vol, 2, National Bureau of Standards, Gaithersburg, MD, 1978, p. 1077.

88. R. Browning, J.L. Smialek, and N.S. Jacobson, "Multielement Mapping of $\alpha-S i C$ by Scanning Auger Microscopy," Adv. Ceram. Mater., 2[4]: 773 (1987).

89. S.C. Singhal and F.F. Lange, "Effect of Alumina Content on the Oxidation of Hot-Pressed Silicon Carbide". J. Am. Ceram. Soc., 58[9-10]: 433 (1975).

90. D. Cubicciotti and K.H. Lau, "Kinetics of Oxidation of Yttria Hot-Pressed Silicon Nitride", J. Electrochem. Soc., 126[10]: 1723 (1979).

91. J.R. Price, R.E. Gildersleeve, M. Van Roode, and C.E. Smeltzer, "A New Ceramic Recuperation Technology for Use in Corrosive Environments", Corrosion of Ceramic Materials Workshop: Proceedings, (B.K. Kennedy, ed.) Center for Advanced Materials, Pennsylvania state University, University Park, PA, 1987, p. 81. 
TABLE I. - CORROSIVE APPLICATIONS FOR CERAMICS

\begin{tabular}{|c|c|c|c|c|}
\hline Application & Temperatures & $\begin{array}{c}\text { Pressures } \\
\text { atm, }\end{array}$ & Atmosphere & Deposit \\
\hline Heat engines & 900 to $1400^{\circ} \mathrm{C}$ & 1 to 50 & 0xidizing & $\mathrm{Na}_{2} \mathrm{SO}_{4}, \mathrm{Na}_{2} \mathrm{~V}_{x} \mathrm{O}_{y}$ \\
\hline Coal combustion & 1200 to $1400{ }^{\circ} \mathrm{C}$ & 1 to 10 & Reducing & Acidic or basic coal slags \\
\hline $\begin{array}{l}\text { Industrial } \\
\text { furnaces }\end{array}$ & 1000 to $1600{ }^{\circ} \mathrm{C}$ & $\sim 1$ & $\begin{array}{l}\text { Oxidizing, } \\
\text { reducing }\end{array}$ & $\begin{array}{l}\mathrm{NaCl}, \mathrm{NaF}, \mathrm{Na}_{2} \mathrm{SO}_{4} \text {, Tran- } \\
\text { sition metal oxides }\end{array}$ \\
\hline $\begin{array}{l}\text { Magneto- } \\
\text { hydrodynamics }\end{array}$ & 1000 to $1400^{\circ} \mathrm{C}$ & 1 to 10 & $\begin{array}{l}\text { Oxidizing, } \\
\text { reducing }\end{array}$ & $\mathrm{K}_{2} \mathrm{CO}_{3}, \mathrm{~K}_{2} \mathrm{SO}_{4}$ \\
\hline Fuel cells & 800 to $1000^{\circ} \mathrm{C}$ & $\sim 1$ & Oxidizing & Alkali carbonates \\
\hline
\end{tabular}

TABLE II.

(a) Types of SiC

\begin{tabular}{|c|c|c|c|}
\hline Designation & Material & $\begin{array}{l}\text { Additives, } \\
\text { impurities }\end{array}$ & Type, manufacturer \\
\hline $\mathrm{SCSC}$ & Single crystal SiC & $\mathrm{Fe}$ & - - \\
\hline CVDSC & $\begin{array}{l}\text { Chemically vapor } \\
\text { deposited SiC }\end{array}$ & ------- & $-\infty$ \\
\hline RSC & Recrystallized SiC & $\begin{array}{l}\sim 18 \text { percent } \\
\text { porous }\end{array}$ & $\begin{array}{l}\text { NC400, Norton Co, } \\
\text { Worcestor, } M A\end{array}$ \\
\hline RBSC & $\begin{array}{l}\text { Reaction bonded SiC } \\
\text { Siliconized SiC }\end{array}$ & $\mathrm{Si}$ & $\begin{array}{l}\text { Various types } \\
\text { e.g. Sohio KX01 } \\
\text { Standard Oil Engineered } \\
\text { Materials Co. } \\
\text { Niagara Falls, NY }\end{array}$ \\
\hline HPSC & Hot pressed SiC & $\mathrm{A}_{2} 2_{3}$ & $\begin{array}{c}\text { NC203, Norton Corp, } \\
\text { Worcestor, MA }\end{array}$ \\
\hline $\operatorname{SSC}(A 1, C)$ & Sintered SiC & $A 1, C$ & 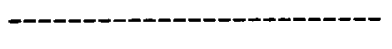 \\
\hline $\operatorname{SASC}(B, C)$ & Sintered $\alpha-\operatorname{SiC}$ & B, C & $\begin{array}{l}\text { Sohio Hexoloy } \\
\text { Standard Oil Engineered } \\
\text { Materials Co. } \\
\text { Niagara Falls. NY }\end{array}$ \\
\hline $\operatorname{SBSC}(B, C)$ & Sintered $B-S i C$ & $B, C$ & General Electric \\
\hline NSSC $(B, C)$ & Sintered SiC & B, C & $\begin{array}{l}\text { NGK Spark Plug Co., Ltd. } \\
\text { Japan }\end{array}$ \\
\hline
\end{tabular}


TABLE II. - Concluded.

(b) Types of $\mathrm{Si}_{3} \mathrm{~N}_{4}$

\begin{tabular}{|c|c|c|c|}
\hline Designation & Material & $\begin{array}{l}\text { Additives, } \\
\text { impurities }\end{array}$ & Type, manufacturer \\
\hline CVDSN & $\begin{array}{l}\text { Chemically } \\
\text { vapor depos- } \\
\text { ited } \mathrm{Si}_{3} \mathrm{~N}_{4}\end{array}$ & - - - - & 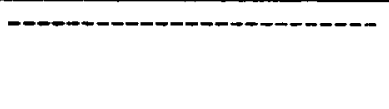 \\
\hline RBSN & $\begin{array}{l}\text { Reaction bonded } \\
\mathrm{Si}_{3} \mathrm{~N}_{4}\end{array}$ & Si & 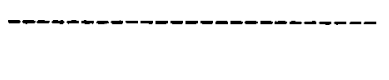 \\
\hline HIP RBSN & $\begin{array}{l}\text { Hot isostatically } \\
\text { pressed reaction } \\
\text { bonded } \mathrm{Si}_{3} \mathrm{~N}_{4}\end{array}$ & Si & See reference 7 \\
\hline HPSN (MgO) & Hot pressed $\mathrm{Si}_{3} \mathrm{~N}_{4}$ & $\mathrm{MgO}$ & $\begin{array}{l}\text { NC132, Norton Corp, } \\
\text { Worcestor, MA }\end{array}$ \\
\hline $\operatorname{HPSN}\left(\mathrm{Y}_{2} \mathrm{O}_{3}\right)$ & Hot pressed $\mathrm{Si}_{3} \mathrm{~N}_{4}$ & $\mathrm{Y}_{2} \mathrm{O}_{3}, \mathrm{WC}$ & $\begin{array}{l}\text { NCX-34, Norton Corp, } \\
\text { Worcestor, MA }\end{array}$ \\
\hline$\underset{\left.\mathrm{Y}_{2} \mathrm{O}_{3}\right)}{\operatorname{SSN}}\left(\mathrm{A}_{3}\right.$ & Sintered $\mathrm{Si}_{3} \mathrm{~N}_{4}$ & $\mathrm{Al}_{2} \mathrm{O}_{3}, \mathrm{Y}_{2} \mathrm{O}_{3}$ & $\begin{array}{l}\text { AY-6, GTE Products Corp, } \\
\text { Towanda, PA }\end{array}$ \\
\hline $\operatorname{SSN}\left(Y_{2} O_{3}\right)$ & Sintered $\mathrm{Si}_{3} \mathrm{~N}_{4}$ & $\mathrm{Y}_{2} \mathrm{O}_{3}$ & $\begin{array}{l}\text { PY-6, GTE Products Corp, } \\
\text { Towanda, PA }\end{array}$ \\
\hline$\underset{\left.\mathrm{Y}_{2} \mathrm{O}_{3}\right)}{\operatorname{HPSN}\left(\mathrm{Al}_{2} \mathrm{O}_{3}\right.}$ & Hot pressed $\mathrm{Si}_{3} \mathrm{~N}_{4}$ & $\mathrm{Al}_{2} \mathrm{O}_{3}, \mathrm{Y}_{2} \mathrm{O}_{3}$ & $\begin{array}{l}\text { Toshiba Ceramic Co., Ltd. } \\
\text { Tokyo, Japan }\end{array}$ \\
\hline$\underset{\left.\mathrm{Y}_{2} \mathrm{O}_{3}\right)}{\operatorname{NSSN}}\left(\mathrm{Al}_{2} \mathrm{O}_{3}\right.$ & Sintered $\mathrm{Si}_{3} \mathrm{~N}_{4}$ & $\mathrm{Al}_{2} \mathrm{O}_{3}, \mathrm{Y}_{2} \mathrm{O}_{3}$ & $\begin{array}{l}\text { NGK Spark Plug Co., Ltd. } \\
\text { Japan }\end{array}$ \\
\hline
\end{tabular}


TABLE III. - SURVEY OF CORROSION STUDIES

(a) Etching studies

\begin{tabular}{|c|c|c|c|c|c|}
\hline Date & Reference & Materials & Corrodents & Technique & Observations \\
\hline 1952 & (8) Horn & scsc & $\mathrm{Na}_{100{ }^{2} \mathrm{CO}_{3}}$ & Crucible & $\begin{array}{l}\text { Pitting at dislo- } \\
\text { cation sites }\end{array}$ \\
\hline 1959 & (9) Faust & & Basic salts & & Pitting \\
\hline 1960 & $\begin{array}{l}\text { (10) Amelinckx } \\
\text { et al. }\end{array}$ & & ${ }_{1000^{-} \mathrm{C}}^{\mathrm{Na}_{2} \mathrm{CO}_{3}}$ & & $\begin{array}{l}\text { Pitting at dislo- } \\
\text { cation sites }\end{array}$ \\
\hline 1963 & $\begin{array}{l}\text { (11) Gabor, } \\
\text { Stickler }\end{array}$ & & $\mathrm{PbO}, \mathrm{PbO}^{-\mathrm{PbF}_{2}}$ & & Pitting \\
\hline 1965 & $\begin{array}{l}\text { (12) Gabor, } \\
\text { Jennings }\end{array}$ & & $\mathrm{NaF}-\mathrm{Na}_{2} \mathrm{SO}_{4}$ & & $\begin{array}{l}\text { Pitting at disloca- } \\
\text { tion and impurity } \\
\text { sites } \\
\text { Etch rate highly } \\
\text { temperature } \\
\text { dependent } \\
\text { At } 1050^{\circ} \mathrm{C} \sim 130 \mathrm{\mu} / \mathrm{min}\end{array}$ \\
\hline 1974 & $\begin{array}{l}\text { (13) Faust, } \\
\text { Liaw }\end{array}$ & & Basic oxides & & $\begin{array}{l}\text { Review of etching } \\
\text { studies }\end{array}$ \\
\hline
\end{tabular}

(b) Heat engines

\begin{tabular}{|c|c|c|c|c|c|}
\hline Date & Reference & Materials & Corrodents & Technique & Observations \\
\hline $1972-74$ & $\begin{array}{l}(14,15) \\
\text { Singhal }\end{array}$ & $\begin{array}{l}\text { HPSC }\left(\mathrm{Al}_{2} 2^{\left.\mathrm{O}_{3}\right)}\right. \\
\text { HPSN }(\mathrm{MgO})\end{array}$ & ${ }_{1100}^{\mathrm{Na}_{2} \mathrm{SO}_{4}} \cdot \mathrm{V}_{2} \mathrm{O}_{5}$ & Burner & $\begin{array}{l}\text { Limited deposition } \\
\text { and corrosian }\end{array}$ \\
\hline 1975 & $\begin{array}{l}\text { (i6) Arendt, } \\
\text { Curran }\end{array}$ & HPSC & $\begin{array}{l}\mathrm{CaF}_{2}-\mathrm{BaF}_{2}-\mathrm{CaSO}_{4} \\
\mathrm{SrF}_{2} \mathrm{MgSO}_{4} \\
\leq 1100{ }^{\circ} \mathrm{C}\end{array}$ & Crucible & $\begin{array}{l}\text { Severe etching by } \\
\text { basic salts } \\
\text { Arrhenius behavior }\end{array}$ \\
\hline $1975-83$ & $\begin{array}{l}(17 \text { to } 20) \\
\text { Schlichting }\end{array}$ & $\begin{array}{l}\text { RBSC } \\
\text { HPSC } \\
\text { SSC (A1) } \\
\text { SSC (B) } \\
\text { RBSN } \\
\text { HPSN }\left(Y_{2} \mathrm{O}_{3}\right) \\
\text { HPSN }(\mathrm{MgO})\end{array}$ & $\begin{array}{l}\mathrm{NaCl}, \mathrm{Na}_{2} \mathrm{CO}_{3} \\
\mathrm{Na}_{2} \mathrm{SO}_{4} \mathrm{~V}_{2}{ }_{5} \\
1000{ }^{2} \text { to }^{2} 1200{ }^{8} \mathrm{C}\end{array}$ & $\begin{array}{l}\text { Crucible, } \\
\text { Burner }\end{array}$ & $\begin{array}{l}\text { Formation of liquid } \\
\mathrm{Na}_{2} \mathrm{O} \cdot \times\left(\mathrm{SiO}_{2}\right) \text { with } \\
\mathrm{Na}_{2} \mathrm{CO}_{3} \text { and } \mathrm{Na}_{2} \mathrm{SO}_{4} \\
\text { leads to rapid } \\
\text { corrosion }\end{array}$ \\
\hline 1976 & $\begin{array}{l}\text { (21) Mckee, } \\
\text { Chatterji }\end{array}$ & $\operatorname{SBSC}(B, C)$ & $\begin{array}{l}\mathrm{Na}_{2} \mathrm{SO}_{4} \\
\mathrm{Na}_{2} \mathrm{SO}_{4}+\mathrm{C} \\
\mathrm{Na}_{2} \mathrm{CO}_{3}\end{array}$ & $\begin{array}{l}\text { Crucible, } \\
\text { Thin film }\end{array}$ & $\begin{array}{l}\text { Limited corrosion in } \\
\text { acidic melts } \\
\text { Dissolution in basic } \\
\text { melts } \\
\text { Active oxidation in } \\
\text { C containing melts } \\
\text { due to low } \mathrm{P}_{2}\left(\mathrm{O}_{2}\right)\end{array}$ \\
\hline
\end{tabular}


TABLE III. - Continued.

(b) Heat engines

\begin{tabular}{|c|c|c|c|c|c|}
\hline Date & Reference & Materials & Corrodents & Technique & Observations \\
\hline $1976-80$ & $\begin{array}{l}\text { (22 to } 24) \\
\text { Tressler } \\
\text { et a1. }\end{array}$ & $\begin{array}{l}\text { RBSC } \\
\text { HPSC }\left(\mathrm{A}_{2} \mathrm{O}_{3}\right) \\
\text { RBSN } \\
\text { HPSN }(\mathrm{MgO})\end{array}$ & $\mathrm{Na}_{2} \mathrm{SO}_{4}(+\mathrm{NaCl})$ & Crucible & $\begin{array}{l}\text { Rapid consumption in } \\
\mathrm{Na}_{2} \mathrm{SO}_{4} \\
\mathrm{SiC}^{2} \mathrm{Corrodes} \text { faster } \\
\text { than } \mathrm{Si}_{3} \mathrm{~N}_{4} \\
\mathrm{Na}, \mathrm{S}, \mathrm{Cl} \text { grain bound- } \\
\text { ary penetration } \\
\text { Severe ( } 50 \text { percent) } \\
\text { strength degra- } \\
\text { dation }\end{array}$ \\
\hline 1977 & $\begin{array}{l}\text { (25) Erdos, } \\
\text { Altorfer }\end{array}$ & $\begin{array}{l}\text { HPSN } \\
\text { RBSN }\end{array}$ & $\begin{array}{l}\mathrm{Na}_{2} \mathrm{SO}_{4} \\
\left(+\mathrm{NaCl}_{1}+\mathrm{V}_{2} \mathrm{O}_{5}\right) \\
\left(+\mathrm{NaCl}+\mathrm{Li}_{2} \mathrm{O}\right) \\
\left(+\mathrm{MgSO}_{4}+\mathrm{CaSO}_{4}\right)\end{array}$ & $\begin{array}{l}\text { Crucible, } \\
\text { Burner }\end{array}$ & $\begin{array}{l}\text { Severe corrosion } \\
\text { with basic salts }\end{array}$ \\
\hline 1977 & $\begin{array}{l}(26,27) \\
\text { Palko, Sims }\end{array}$ & $\begin{array}{l}\text { HPSC } \\
\text { HPSN } \\
\text { SSC }\end{array}$ & $\begin{array}{l}\mathrm{Na}_{2} \mathrm{SO}_{4}, \mathrm{~V}_{2} \mathrm{O}_{5} \\
800 \text { to } 1160^{\circ} \mathrm{C}\end{array}$ & Burner & $\begin{array}{l}\text { Limited corrodent } \\
\text { penetration } \\
-25 \mu \mathrm{m} / 1000 \mathrm{hr}\end{array}$ \\
\hline 1978 & $\begin{array}{l}(28,29) \\
\text { Mayer, Riley }\end{array}$ & RBSN & $\begin{array}{l}\mathrm{Na}_{2} \mathrm{CO}_{3}, \mathrm{Na}_{2} \mathrm{SO}_{4}, \\
800 \text { to } 1300{ }^{\circ} \mathrm{C}\end{array}$ & $\begin{array}{l}\text { filn, } \\
\text { Salt } \\
\text { vapor }\end{array}$ & $\begin{array}{l}\mathrm{Na}_{2} \mathrm{CO}_{3} \text { : Initial rapid } \\
\mathrm{Ha}_{2} \mathrm{O} \cdot \times\left(\mathrm{SiO}_{2}\right) \text { forma- } \\
\text { tion, reaction } \\
\text { slows with } \mathrm{SiO}_{2} \\
\text { formation } \\
\mathrm{Na}_{2} \mathrm{SO}_{4} \text {. } \mathrm{NaCl} \text { vapors: } \\
\mathrm{Ha}_{2} \mathrm{O} \cdot \times\left(\mathrm{SiO}_{2}\right) \\
\text { formation }\end{array}$ \\
\hline 1978 & $\begin{array}{l}\text { (30) Levy, } \\
\text { Falco }\end{array}$ & RBSN & ${ }_{1093}^{\mathrm{Na}_{2} \mathrm{CO}_{3} ;}, \mathrm{Na}_{2} \mathrm{SO}_{4}$ & Film & $\begin{array}{l}\text { Friable corrosion } \\
\text { products } \\
\text { Extensive surface } \\
\text { roughening }\end{array}$ \\
\hline $1978-81$ & $\begin{array}{l}(31,32) \\
\text { Richerson } \\
\text { et al. }\end{array}$ & $\begin{array}{l}\text { HPSN }(\mathrm{MgO}) \\
\text { RBSN }\end{array}$ & $\mathrm{Na}_{2} \mathrm{SO}_{4}, 125{ }^{\circ} \mathrm{C}$ & Burner & $\begin{array}{l}\text { Glassy corrosion } \\
\text { products } \\
\text { Strength degradation }\end{array}$ \\
\hline 1978 & $\begin{array}{l}\text { (33) Brooks, } \\
\text { Meadowcroft }\end{array}$ & $\begin{array}{l}\text { RBSC } \\
\text { RBSN } \\
\text { HPSN }\end{array}$ & $\mathrm{Na}_{90} \mathrm{SO}_{4}, \mathrm{~V}_{2} \mathrm{O}_{5}$ to $1400^{\circ} \mathrm{C}$ & $\begin{array}{l}\text { Crucible, } \\
\text { Burner }\end{array}$ & $\begin{array}{l}\text { Extensive deposition } \\
\text { and corrosion } \\
\mathrm{Na}_{2} \mathrm{O} \cdot \times\left(\mathrm{SiO}_{2}\right) \text { forma- } \\
\text { Eion }\end{array}$ \\
\hline 1979 & $\begin{array}{l}\text { (34) Barkalow, } \\
\text { Pettit }\end{array}$ & $\mathrm{Si}_{3} \mathrm{~N}_{4}$ & $\mathrm{Na}_{2} \mathrm{SO}_{4}-982{ }^{\circ} \mathrm{C}$ & Filn & $\begin{array}{l}\text { More attack with } \\
\text { lower } \mathrm{P}_{\left(\mathrm{SO}_{3}\right)-} \\
\text { basic } \mathrm{Na}_{2} \mathrm{SO}_{4}\end{array}$ \\
\hline 1979 & (35) Katz & $\mathrm{Si}_{3} \mathrm{~N}_{4} \cdot \mathrm{SiC}$ & $\mathrm{Na}_{2} \mathrm{SO}_{4}, \mathrm{~V}_{2} \mathrm{O}_{5}$ & Burner & $\begin{array}{l}\text { Review - points out } \\
\text { need for more data }\end{array}$ \\
\hline
\end{tabular}


TABLE III. - Continued.

(b) Heat engines

\begin{tabular}{|c|c|c|c|c|c|}
\hline Date & Reference & Materials & Corrodents & Technique & Observations \\
\hline 1979 & (36) Cavallotti & $\begin{array}{l}\text { HPSN }\left(\mathrm{Y}_{2} \mathrm{O}_{3}, \mathrm{MgO}\right) \\
\text { RBSN }\left(\mathrm{Fe}_{2} \mathrm{O}_{3}, \mathrm{MgO}\right) \\
\text { RBSSN }\left(\mathrm{Y}_{2} \mathrm{O}_{3}, \mathrm{MgO}\right) \\
\text { SSN }\left(\mathrm{Y}_{2} \mathrm{O}_{3}, \mathrm{MgO}\right)\end{array}$ & $\mathrm{NaCl}, \mathrm{Na}_{2} \mathrm{SO}_{4}$ & Film & $\begin{array}{l}\text { Formation of } \\
\mathrm{Na}_{2} \mathrm{O} \cdot \times\left(\mathrm{SiO}_{2}\right) \\
\text { RBSN corrodes the } \\
\text { most }\end{array}$ \\
\hline 1980 & $\begin{array}{l}\text { (37) Schwab, } \\
\text { Kotchick }\end{array}$ & SASC $(B, C)$ & $\begin{array}{l}\text { Sea salt } \\
1200^{\circ} \text { to } 1400^{\circ} \mathrm{C}\end{array}$ & $\mathrm{Fi} 7 \mathrm{~m}$ & $\begin{array}{l}\text { Enhanced slow crack } \\
\text { growth with salt } \\
\text { deposit }\end{array}$ \\
\hline 1982 & (38) Napier & $\begin{array}{l}\text { RBSC } \\
\text { HPSN }\end{array}$ & $\begin{array}{l}\mathrm{NaCl}+\mathrm{Na}_{2} \mathrm{SO}_{4} \\
\mathrm{MgSO}_{4}+\mathrm{Na}_{2} \mathrm{SO}_{4} \\
\mathrm{~V}_{2} \mathrm{O}_{5}+\mathrm{Na}_{2} \mathrm{CO}_{3} \\
593{ }^{\circ} \mathrm{C}, 871^{8} \mathrm{C}\end{array}$ & Film & $\begin{array}{l}\text { No strength decrease } \\
\text { for RBSC } \\
\sim 50 \text { percent strength } \\
\text { decrease for HP } \\
\mathrm{Si}_{3} \mathrm{~N}_{4}+\left(\mathrm{V}_{2} \mathrm{O}_{5}+\right. \\
\left.\mathrm{Na}_{2} \mathrm{CO}_{3}\right)\end{array}$ \\
\hline $1984-85$ & $\begin{array}{l}(39 \text { to } 41) \\
\text { Blachere. } \\
\text { Pettit }\end{array}$ & $\begin{array}{l}\operatorname{SCSC} \\
\operatorname{CVDSC} \\
\operatorname{MPSC}\left(\mathrm{A}_{2} \mathrm{O}_{3}\right) \\
\operatorname{CVDSN} \\
\operatorname{HPSN}\left(\mathrm{Y}_{2} \mathrm{O}_{3}\right)\end{array}$ & $\begin{array}{l}\mathrm{Na}_{2} \mathrm{SO}_{4} \\
1000^{\circ} \mathrm{C}\end{array}$ & Film & 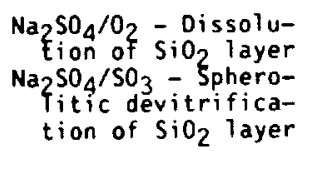 \\
\hline 1985 & (42) Fielder & $\operatorname{HPSN}\left(\mathrm{Y}_{2} \mathrm{O}_{3}\right)$ & $\mathrm{Na}_{2} \mathrm{SO}_{4}$ & film & $\begin{array}{l}\text { Incubation period, } \\
\text { massive liquid } \\
\mathrm{Na}^{0} \mathrm{O} \cdot \mathrm{x}\left(\mathrm{SiO}_{2}\right) \text { scales } \\
\text { with bubbles, } \mathrm{SO}_{2} \\
\text { evolution }\end{array}$ \\
\hline 1986 & $\begin{array}{l}(43,44) \\
\text { Gogotsi } \\
\text { et al. }\end{array}$ & $\mathrm{Si}_{3^{\mathrm{N}}}{ }^{\mathrm{N}}-\mathrm{SiC}-\mathrm{MgO}$ & $\underset{\mathrm{Na}_{2} \mathrm{SO}_{4}}{\mathrm{NaCl}}$ Sea salt, & $\begin{array}{l}\text { Crucible, } \\
\text { film }\end{array}$ & $\begin{array}{l}\mathrm{Na}_{2} \mathrm{SO}_{4}-\text { Most corro- } \\
\text { sive salt } \\
\text { Strength and } \mathrm{K}_{\mathrm{I}} \\
\text { degradation with } \\
\text { all salts }\end{array}$ \\
\hline $1986-88$ & $\begin{array}{l}\text { (45 to } 55) \\
\text { Jacobson, } \\
\text { Smialek, fox }\end{array}$ & $\begin{array}{l}\text { SCSC } \\
\text { CVDSC } \\
\text { SASC }(B, C) \\
\text { HPSC }\left(\mathrm{AI}_{2} \mathrm{O}_{3}\right) \\
\text { CVOSN } \\
\text { HIP RBSN } \\
\text { SSN }\left(\mathrm{Y}_{2} \mathrm{O}_{3}, \mathrm{Al}_{2} \mathrm{O}_{3}\right) \\
\text { SSN }\left(Y_{2} \mathrm{O}_{3}\right) \\
\text { HPSN }\left(\mathrm{FgO}_{3}\right)\end{array}$ & ${ }^{\mathrm{Na}_{2} \mathrm{SO}_{4}} \cdot \mathrm{Na}_{2} \mathrm{CO} \mathrm{CO}_{3}$ & $\begin{array}{l}\text { Film, } \\
\text { Burner } \\
\quad \text { rig }\end{array}$ & $\begin{array}{l}\text { Severe attach by } \\
\text { basic molten salts } \\
\text { due to coupled } \\
\text { oxidation- } \\
\text { dissolution } \\
\text { Carbon can drive } \\
\text { Na2 } \mathrm{SO}_{4} \text { basic } \\
\text { Severe pitting in } \mathrm{SiC} \\
\text { leads to strength } \\
\text { reduction: grain } \\
\text { boundary attack in } \\
\mathrm{Si}_{3} \mathrm{~N}_{4} \\
\end{array}$ \\
\hline
\end{tabular}


TABLE III. - Continued.

(b) Heat engines

\begin{tabular}{|c|c|c|c|c|c|}
\hline Date & Reference & Materials & Corrodents & Technique & Observations \\
\hline 1987 & $\begin{array}{l}\text { (56) Tighe } \\
\text { et al. }\end{array}$ & $\operatorname{SASC}(B, C)$ & $\mathrm{Na}_{2} \mathrm{CO}_{3}$ & Thin film & $\begin{array}{l}\text { Dissolution at grain } \\
\text { boundaries and } \\
\text { intergranular } \\
\text { faults }\end{array}$ \\
\hline 1988 & $\begin{array}{l}\text { (57) Henninger, } \\
\text { Jones }\end{array}$ & $\operatorname{HPSN}\left(Y_{2} \mathrm{O}_{3}\right)$ & $\mathrm{Na}_{2} \mathrm{SO}_{4}$ & Film & $\begin{array}{l}\text { Enhanced slow crack } \\
\text { growth, due to } \\
\mathrm{SiO}_{2} \text { dissolution }\end{array}$ \\
\hline 1988 & (58) Nagarajan & $\mathrm{SiC}$ & $\mathrm{Na}_{2} \mathrm{SO}_{4}$ & - - & $\begin{array}{l}\text { Theoretical discus- } \\
\text { sion on deposition } \\
\text { of } \mathrm{Na}_{2} \mathrm{SO}_{4} \text { and dis- } \\
\text { solution of } \mathrm{SiO}_{2}\end{array}$ \\
\hline
\end{tabular}

(c) Coal combustion

\begin{tabular}{|c|c|c|c|c|c|}
\hline Date & Reference & Materials & Corrodents & Technique & Observations \\
\hline $1981-86$ & $\begin{array}{l}\text { (59 to } 64) \\
\text { Ferber, } \\
\text { Becher et al. }\end{array}$ & $\begin{array}{l}\text { CVDSC } \\
\text { RBSC } \\
\text { SASC }(B, C)\end{array}$ & $\begin{array}{l}\text { Acidic coal slag } \\
\text { Basic coal slag }\end{array}$ & $\begin{array}{l}\text { Burner, } \\
\text { F } ¥ \operatorname{lm}\end{array}$ & $\begin{array}{l}\text { Extensive surface } \\
\text { recession with } \\
\text { basic slags } \\
\text { Pitting due to forma- } \\
\text { tion of ( } \mathrm{Fe} \text {, Ni) } \\
\text { silicide leads to } \\
\text { strength reduction } \\
\text { Strength degradation- } \\
\text { material and slag } \\
\text { dependent }\end{array}$ \\
\hline $1984-85$ & $\begin{array}{l}(65 \text { to } 68) \\
\text { Easler } \\
\text { Poeppe }\end{array}$ & $\begin{array}{l}\text { RBSC } \\
\text { SASC (B, C) }\end{array}$ & $\begin{array}{l}\text { Acidic coal slag } \\
\text { Basic coal slag }\end{array}$ & Film & $\begin{array}{l}\text { More attack and } \\
\text { strength reduction } \\
\text { from basic slag } \\
\text { Penetration of } \mathrm{Fe} \\
\text { along grain } \\
\text { boundaries } \\
\text { Formation of } \mathrm{SiO}_{2} \\
\text { healing layer } \\
\text { between slag and } \\
\text { SiC }\end{array}$ \\
\hline
\end{tabular}


TABLE III. - Continued.

(d) Industrial furnaces

\begin{tabular}{|c|c|c|c|c|c|}
\hline Date & Reference & Materials & Corrodents & Technique & Observations \\
\hline 1974 & $\begin{array}{l}\text { (69) Buchner, } \\
\text { Rubisch }\end{array}$ & RBSC & $\begin{array}{l}\mathrm{Na}_{2} \mathrm{CO}_{3} \\
\leq 900{ }^{8} \mathrm{C}\end{array}$ & Crucible & Complete dissolution \\
\hline 1979 & $\begin{array}{l}\text { (70) Weber, } \\
\text { Tennery }\end{array}$ & $\begin{array}{l}\text { CVDSC } \\
\text { RSC } \\
\text { RBSC } \\
\text { SASC }(B, C)\end{array}$ & $\begin{array}{l}\text { Glass melting } \\
\text { furnace } \\
1150^{\circ} 15500^{\circ} \mathrm{C}\end{array}$ & $\begin{array}{l}\text { Actual } \\
\text { Furnace }\end{array}$ & $\begin{array}{l}\text { Extensive corrosion } \\
\text { when alkali salts } \\
\text { deposited at lower } \\
\text { temperatures }\end{array}$ \\
\hline 1984 & (71) Wei, White & $\operatorname{SASC}(B, C)$ & $\begin{array}{l}\text { Stee } 7 \text { soaking pit } \\
1250 \circ \mathrm{C}\end{array}$ & $\begin{array}{l}\text { Actual } \\
\text { Furnace }\end{array}$ & $\begin{array}{l}\text { Slag deposit, but no } \\
\text { appreciable } \\
\text { degradation }\end{array}$ \\
\hline 1985 & $\begin{array}{l}(72 \text { to } 73) \\
\text { Federer } \\
\text { et al. }\end{array}$ & $\begin{array}{l}\text { CVDSC } \\
\text { RSC } \\
\text { RBSC } \\
\text { SASC }(B, C)\end{array}$ & $\begin{array}{l}\text { A] remelt furnace } \\
\text { Forge furnace } \\
\text { Steel reheat } \\
\text { furnace } \\
\text { Steel soaking } \\
\text { pits }\end{array}$ & $\begin{array}{l}\text { Actual } \\
\text { Furnace }\end{array}$ & $\begin{array}{l}\text { Degradation in } A 1 \\
\text { remelt furnace and } \\
\text { in one steel } \\
\text { soaking pit }\end{array}$ \\
\hline $1985-88$ & $\begin{array}{l}(74 \text { to } 76) \\
\text { Federer } \\
\text { et al. }\end{array}$ & $\begin{array}{l}\text { RBSC } \\
\text { SASC (B, C) } \\
1200^{\circ} \mathrm{C}\end{array}$ & $\begin{array}{l}\mathrm{NaCl} \\
\mathrm{Naf} \\
1200{ }^{\circ} \mathrm{C}\end{array}$ & Vapor & $\begin{array}{l}\mathrm{Na}_{2} \mathrm{O} \text { formed from } \mathrm{NaCl} \\
\text { feads to } \\
\mathrm{Na}_{2} \mathrm{O} \cdot \times\left(\mathrm{SiO}_{2}\right) \\
\text { Surface recession } \\
\text { Early failure under } \\
\text { stress }\end{array}$ \\
\hline 1986 & (77) Federer & $\begin{array}{l}\text { Various SiC. } \\
\mathrm{Si}_{3} \mathrm{~N}_{4}\end{array}$ & $\begin{array}{l}\text { Industrial } \\
\text { furnaces } \\
\text { Coal combustors }\end{array}$ & - - - - & $\begin{array}{l}\text { Summary of corrosion } \\
\text { tests in industrial } \\
\text { furnaces and coal } \\
\text { combustion }\end{array}$ \\
\hline 1987 & $\begin{array}{l}(78) \\
\text { Van Ackeren }\end{array}$ & $\begin{array}{l}\text { RBSC } \\
\text { SASC }(B, C)\end{array}$ & $\begin{array}{l}\text { Steel soaking pit } \\
\text { Forging furnace } \\
\text { Al Remelt - con- } \\
\text { tinuous fluxing } \\
\text { Al Remelt - non- } \\
\text { fluxing }\end{array}$ & $\begin{array}{l}\text { Actual } \\
\text { Furnace }\end{array}$ & $\begin{array}{l}\text { Most corrosion in } \\
\text { continuous fluxing } \\
\text { furnace (contains } \\
\text { salts) }\end{array}$ \\
\hline 1987 & $\begin{array}{l}\text { (79) Cree, } \\
\text { Amateau }\end{array}$ & $\operatorname{SASC}(B, C)$ & $\begin{array}{l}\text { LiF, LiCl, LiS, } \\
\text { Liso } 4, \operatorname{Li}^{\circ} \\
200 \text { to } 1000{ }^{\circ} \mathrm{C}\end{array}$ & Film & $\begin{array}{l}\text { Scale dissolution, } \mathrm{Li} \\
\text { penetration }\end{array}$ \\
\hline
\end{tabular}

TABLE III. - Concluded.

(e) MHD, Fuel cells

\begin{tabular}{|c|c|c|c|c|c|}
\hline Date & Reference & Materials & Corrodents & Technique & Observations \\
\hline $1986-87$ & $\begin{array}{l}(80 \text { to } 83) \\
\text { Shimada } \\
\text { et al. }\end{array}$ & $\begin{array}{l}\text { NSSC } \\
\text { NSSN }\left(Y_{2} \mathrm{O}_{3}\right. \\
\mathrm{Al}_{2} \mathrm{O}_{3}\end{array}$ & $\mathrm{~K}_{2} \mathrm{SO}_{4}-\mathrm{K}_{2} \mathrm{CO}_{3}$ & Crucible & $\begin{array}{l}\text { Dissolution of } \mathrm{SiC} \text {, } \\
\mathrm{Si}^{\mathrm{N}} 4 \\
20 \text { to } 30 \text { percent } \\
\text { strength degradation } \\
\text { AlN shows good corr- } \\
\text { sion resistance }\end{array}$ \\
\hline 1987 & $\begin{array}{l}\text { (84) Tajiri } \\
\text { et al. }\end{array}$ & 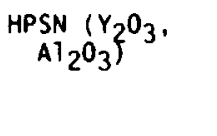 & $\begin{array}{c}\mathrm{Li}_{2} \mathrm{CO}_{3}, \mathrm{Na}_{2} \mathrm{CO}_{3} \\
\mathrm{~K}_{2} \mathrm{CO}_{3}\end{array}$ & Crucible & $\begin{array}{l}\text { Corrosion rates } \\
\quad \mathrm{Li}_{2} \mathrm{CO}_{3}, \mathrm{Na}_{2} \mathrm{CO}_{3} \\
>\mathrm{K}_{2} \mathrm{CO}_{3}\end{array}$ \\
\hline
\end{tabular}


TABLE IV. - DEW POINTS FOR $\mathrm{Na}_{2} \mathrm{SO}_{4}$ DEPOSITION

[Temperatures in degrees Celsius, salt concentrations in parts per million. Deposit is liquid unless noted.]

\begin{tabular}{|c|c|c|c|c|c|c|}
\hline $\begin{array}{l}\text { Percent } S \\
\text { in fuel }\end{array}$ & $\begin{array}{l}\text { Pim } \\
\text { atm }\end{array}$ & $0.001 \mathrm{Na}$ & $0.01 \mathrm{Na}$ & $0.1 \mathrm{Na}$ & $1.0 \mathrm{Na}$ & $10 \mathrm{Na}$ \\
\hline 0.5 & $\begin{array}{r}1 \\
5 \\
10 \\
50 \\
100\end{array}$ & $\begin{array}{r}a_{747} \\
a_{793} \\
a_{814} \\
a_{867} \\
893\end{array}$ & $\begin{array}{r}a_{814} \\
a_{867} \\
892 \\
958 \\
989\end{array}$ & $\begin{array}{r}887 \\
953 \\
984 \\
1062 \\
1098\end{array}$ & $\begin{array}{r}961 \\
1039 \\
1075 \\
1166 \\
1208\end{array}$ & $\begin{array}{l}1025 \\
1113 \\
1155 \\
1260 \\
1310\end{array}$ \\
\hline 0.05 & $\begin{array}{r}1 \\
5 \\
10 \\
50 \\
100\end{array}$ & $\begin{array}{r}a_{746} \\
a_{792} \\
a_{813} \\
a_{865} \\
889\end{array}$ & $\begin{array}{r}a_{810} \\
a_{862} \\
887 \\
951 \\
980\end{array}$ & $\begin{array}{r}\alpha_{876} \\
940 \\
969 \\
1042 \\
1076\end{array}$ & $\begin{array}{r}937 \\
1011 \\
1045 \\
1130 \\
1169\end{array}$ & $\begin{array}{r}991 \\
1072 \\
1111 \\
1207 \\
1252\end{array}$ \\
\hline
\end{tabular}

asolid.

TABLE V. - TYPICAL COAL SLAG COMPOSITIONa

\begin{tabular}{|c|c|c|}
\hline & Acidic & Basic \\
\hline $\mathrm{SiO}_{2}$ & 54 & 46 \\
\hline $\mathrm{Fe}_{2} \mathrm{O}_{3}$ & 21 & 11 \\
\hline$\left.{ }^{A}\right]_{2} \mathrm{O}_{3}$ & 19 & 14 \\
\hline $\mathrm{CaO}$ & 0.1 & 19 \\
\hline $\mathrm{MgO}$ & 0.9 & 7 \\
\hline $\mathrm{Na}_{2} \mathrm{O}$ & 0.6 & 1.1 \\
\hline $\mathrm{K}_{2} \mathrm{O}$ & 1.7 & 0.5 \\
\hline $\mathrm{TiO}_{2}$ & 1.3 & 0.3 \\
\hline $\begin{array}{l}\text { Ratio basic oxides } \\
\text { to acidic oxides }\end{array}$ & 0.29 & 1.14 \\
\hline
\end{tabular}

TABLE VI. - CHEMICAL ANALYSIS RESULTS

$\left[\mathrm{SiC}, \mathrm{Si}_{3} \mathrm{~N}_{4}+\mathrm{Na}_{2} \mathrm{SO}_{4} / .01 \mathrm{SO}_{3}-\mathrm{O}_{2}-48 \mathrm{hr}, 1000{ }^{\circ} \mathrm{C}.\right]$

\begin{tabular}{|c|c|c|c|c|}
\hline \multirow[t]{3}{*}{ Material } & \multicolumn{3}{|c|}{ Water soluble } & \multirow{3}{*}{$\begin{array}{l}\text { Water insoluble } \\
\mathrm{SiO}_{2} \cdot 2 \\
\mathrm{mg} / \mathrm{cm}^{2}\end{array}$} \\
\hline & \multirow{2}{*}{$\begin{array}{c}\mathrm{Na}_{2} \mathrm{SO}_{4} \\
\mathrm{mg} / \mathrm{cm}^{2}\end{array}$} & \multicolumn{2}{|c|}{$\mathrm{Na}_{2} \mathrm{O} \cdot \times\left(\mathrm{SiO}_{2}\right)$} & \\
\hline & & $\mathrm{mg} / \mathrm{cm}^{2}$ & $x$ & \\
\hline $\begin{array}{l}\text { SCSC } \\
\text { HPSC } \\
\text { SASC }(B, C) \\
\text { SSN }\left(\mathrm{Y}_{2} \mathrm{O}_{3}, \mathrm{Al}_{2} \mathrm{O}_{3}\right)\end{array}$ & $\begin{array}{l}1.64 \pm 0.86 \\
2.01 \pm 0.03 \\
0.49 \pm 0.06 \\
0.23 \pm 0.11\end{array}$ & $\begin{array}{l}<0.01 \\
<0.01 \\
0.97 \pm 0.28\end{array}$ & $1.6 \pm 0.9$ & $\begin{array}{r}1.82 \pm 0.96 \\
0.39 \pm 0.02 \\
10.50 \pm 0.66 \\
1.3 \pm 0.2\end{array}$ \\
\hline
\end{tabular}

TABLE VII. - PIT SIZE DISTRIBUTIONS FOR CORROOEO

SASC $(B, C)--N U M B E R$ OF PITS PER $1 \mathrm{~mm}^{2}$ AREA

\begin{tabular}{|l|c|c|c|}
\hline & $\begin{array}{c}\text { Diameter } \\
<10 \mu \mathrm{m}\end{array}$ & $\begin{array}{c}10 \mu \mathrm{m} \\
<\text { diameter } \\
20 \mu \mathrm{m}\end{array}$ & $\begin{array}{c}\text { Diameter } \\
20 \mu \mathrm{m}\end{array}$ \\
\hline $\mathrm{Na}_{2} \mathrm{SO}_{4} / \mathrm{SO}_{3}$ & 1,880 & 620 & 90 \\
$\mathrm{Na}_{2} \mathrm{CO}_{3} / \mathrm{CO}_{2}$ & 2,280 & 30 & 4 \\
$\mathrm{Na}_{2} \mathrm{SO}_{4} / \mathrm{AIR}$ & 17,280 & 120 & 6 \\
\hline
\end{tabular}




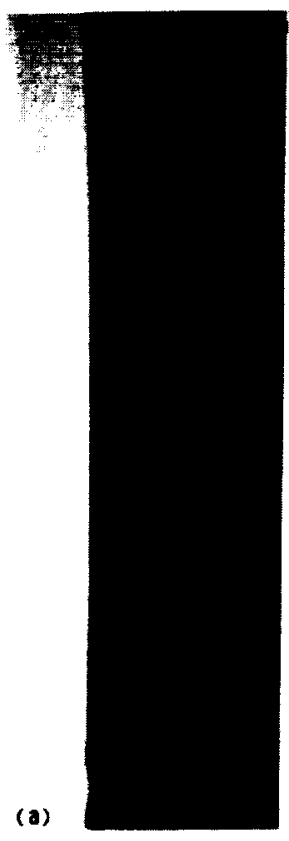

(a) 46 HR WIIH NO Na.

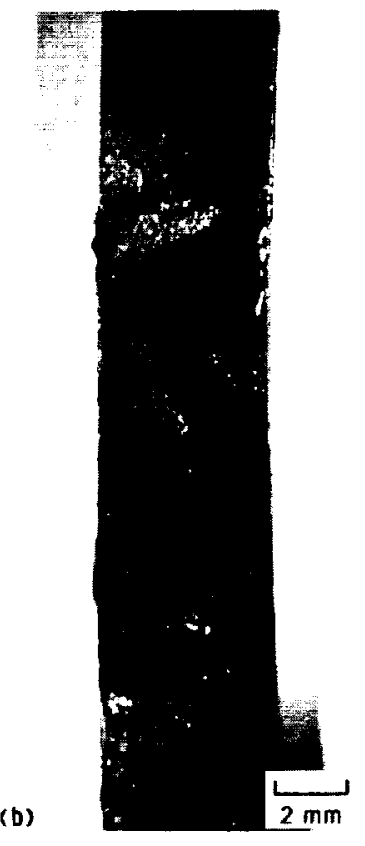

(b) $13.5 \mathrm{HR}$ WITH 4 PPM Na. LEADING EDGE IS ON LEFT.

FIGURE 1. - OPTICAL MICROGRAPHS OF SASC (B,C) TREATED IN THE BURNER RIG AI $1000^{\circ} \mathrm{C}$ HITH JET A FUEL.

OF POOF QURLITY
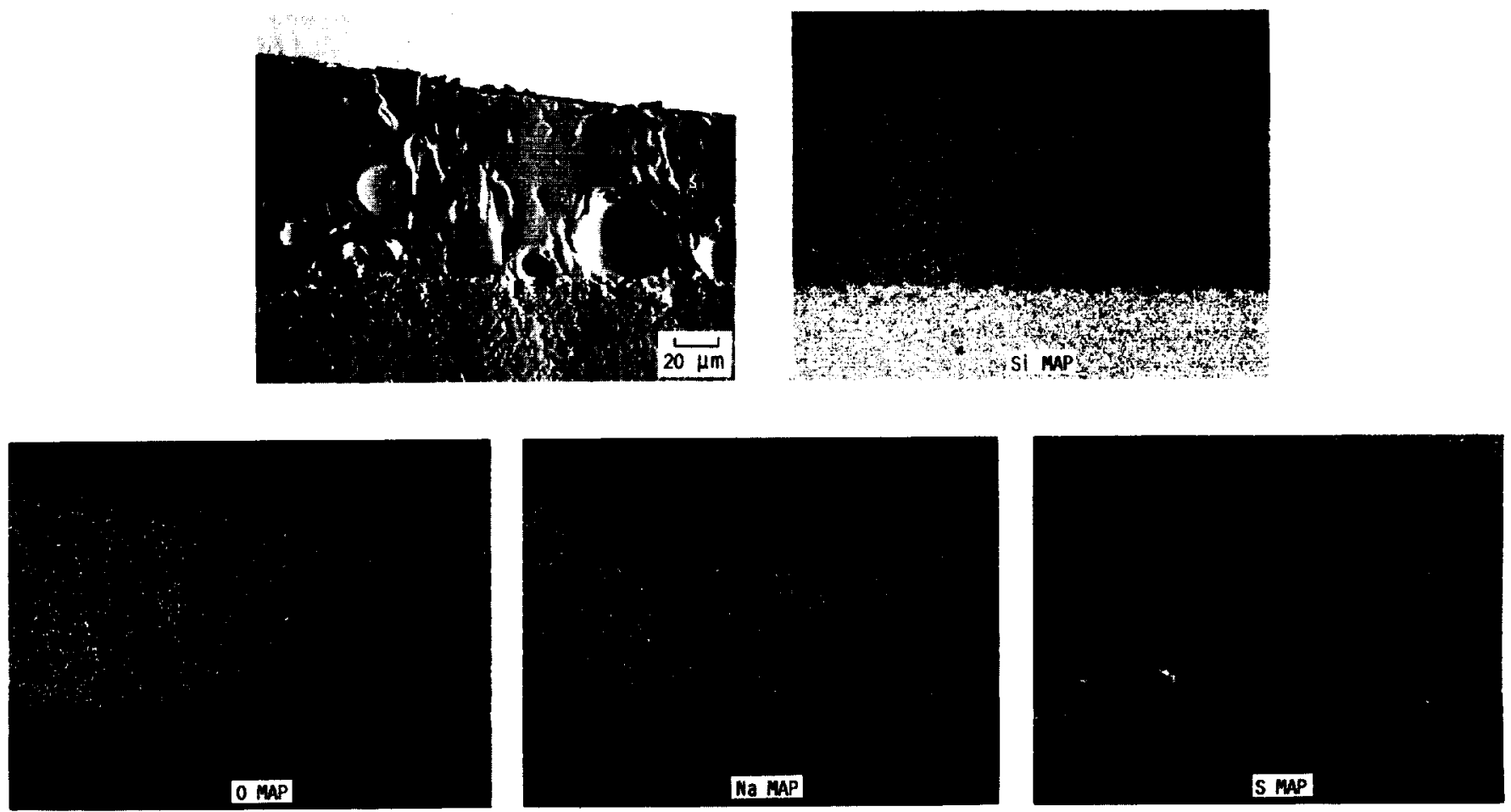

FIGURE 2. - ELECTRON MICROPROBE ANALYSIS OF A POLISHED CROSS SECTION OF GLASSY PRODUCTS ON SASC (B,C) FORMED BY BURNER RIG CORROSION AT $1000{ }^{\circ} \mathrm{C}$ WITH JET A FUEL. FOR 13.5 HR WITH 4 PPM Na. 


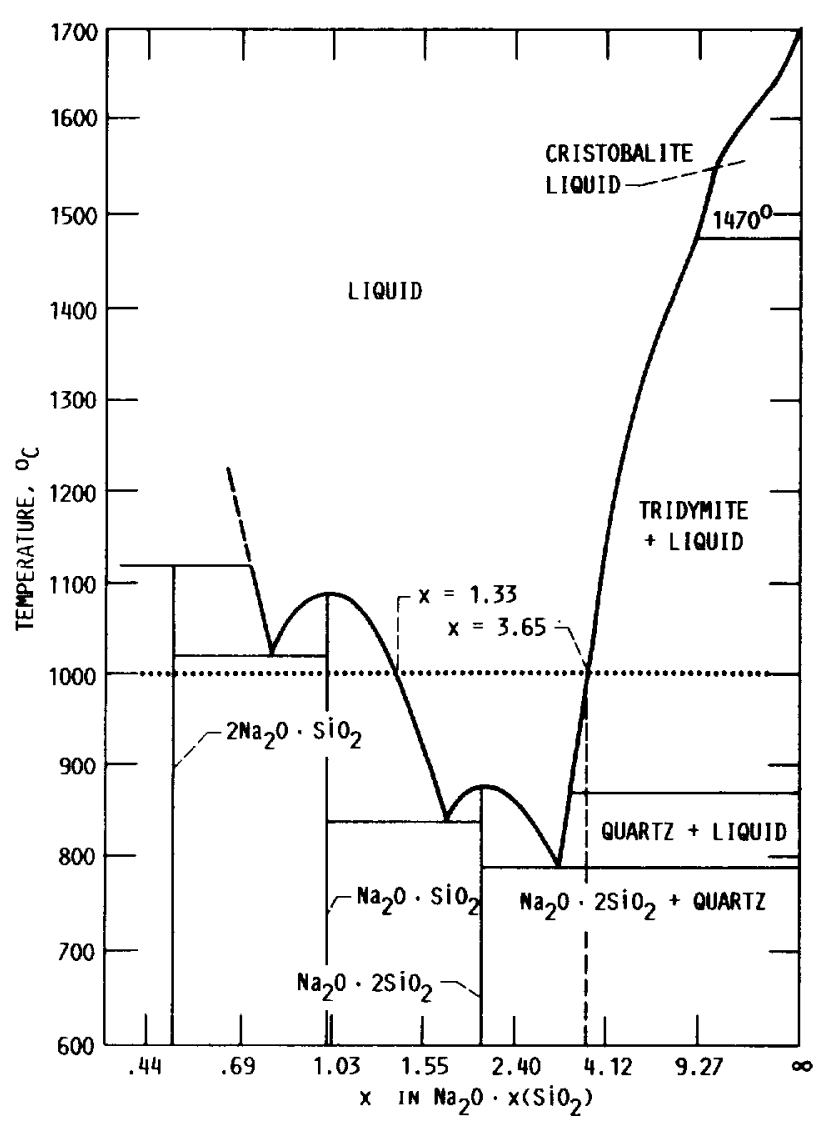

FIGURE 3. - $\mathrm{Na}_{2} \mathrm{O}-\mathrm{SiO}_{2}$ PHASE DIAGRAM.

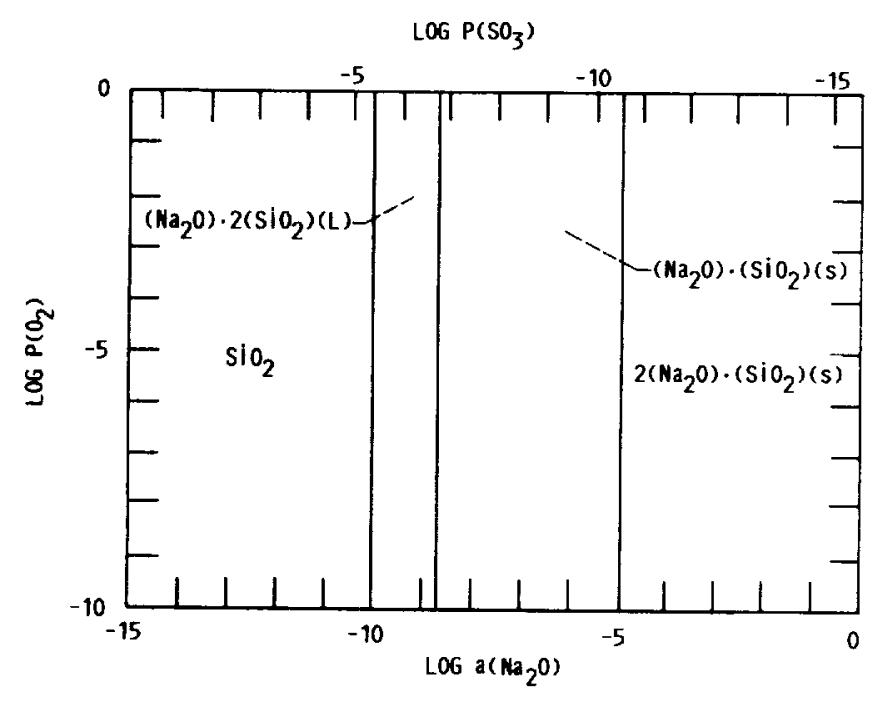

FIGURE 4. - Si-0-Ma STABILITY DIAGRAM.

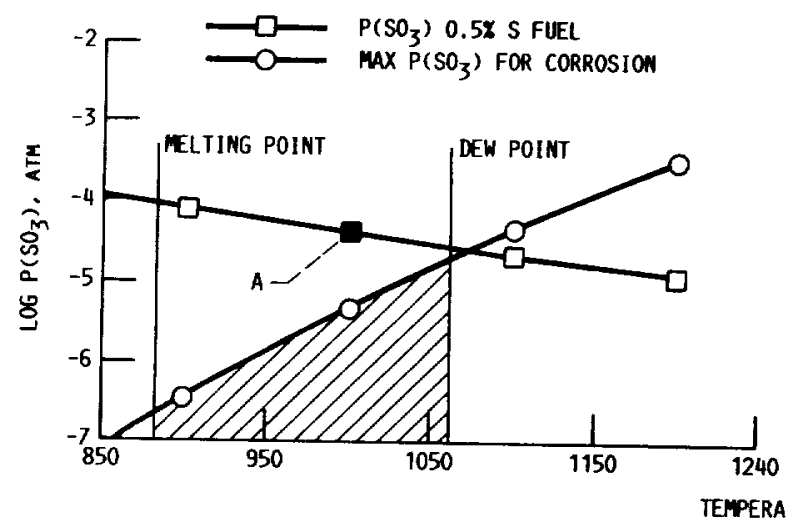

(a) $0.5 \%$ S FUEL, 2 PPM Na, 0.025 FUEL-TO-AIR RATI0, $1000^{\circ} \mathrm{C}$.

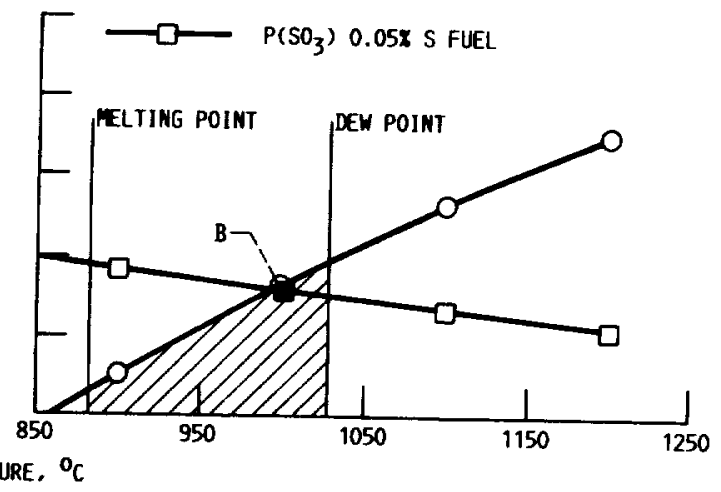

(b) $0.05 \% \mathrm{~S}$ FUEL, 2 PPM Na, 0.025 FUEL-TO-AIR RATIO, $1000^{\circ} \mathrm{C}$.

FIGURE 5. - CALCULATED CORROSION REgImES FOR $\mathrm{SiO}_{2}$. 


\section{OREBirin TAE IS \\ OF. POOR QUALITY}

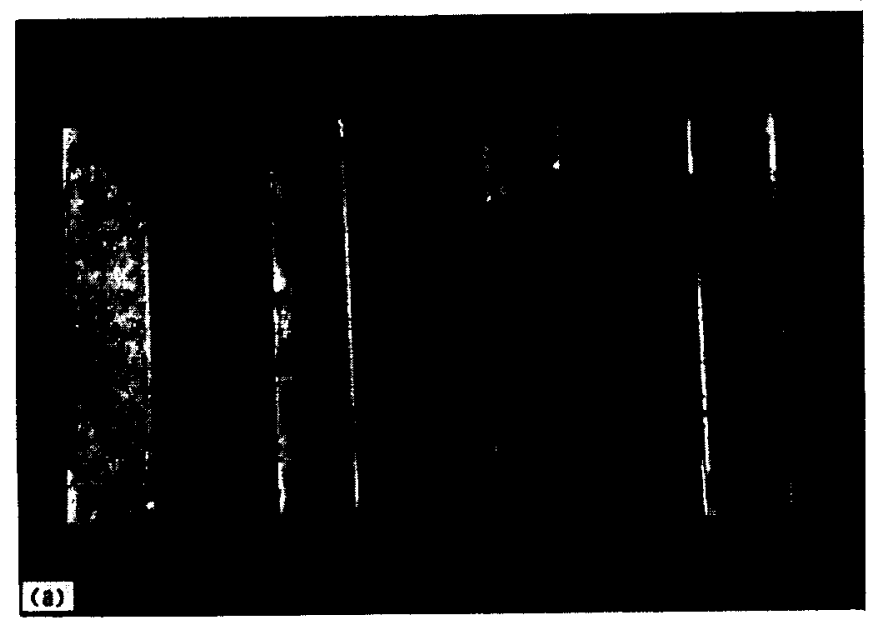

(a) NUMBER 2 DIESEL FUEL $(0.5 \% \mathrm{~S}), 5 \mathrm{HR}$.

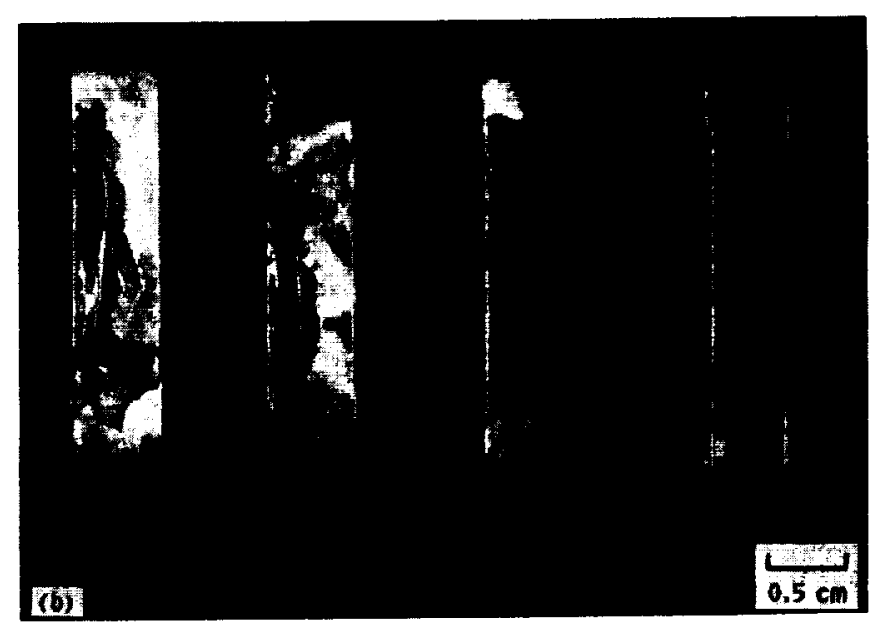

(b) JET A FUEL $(0.05 \times$ S), 1 HR.

Figure 6 . $-\mathrm{SiO}_{2}$ COUPONS tReATEd IN THE BURNER RIG, 2 PPM Na, $1000{ }^{\circ} \mathrm{C}$.

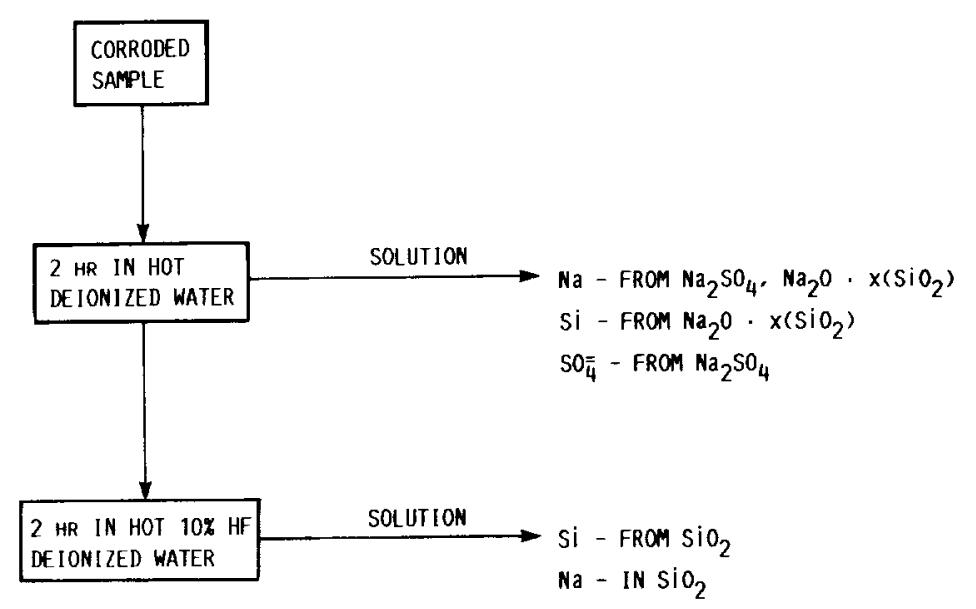

FIGURE 7. - CHEMICAL ANALYSIS SCHEME FOR DETERMINING COMPOSITION OF CORROSION PRODUCTS ON SIC. 


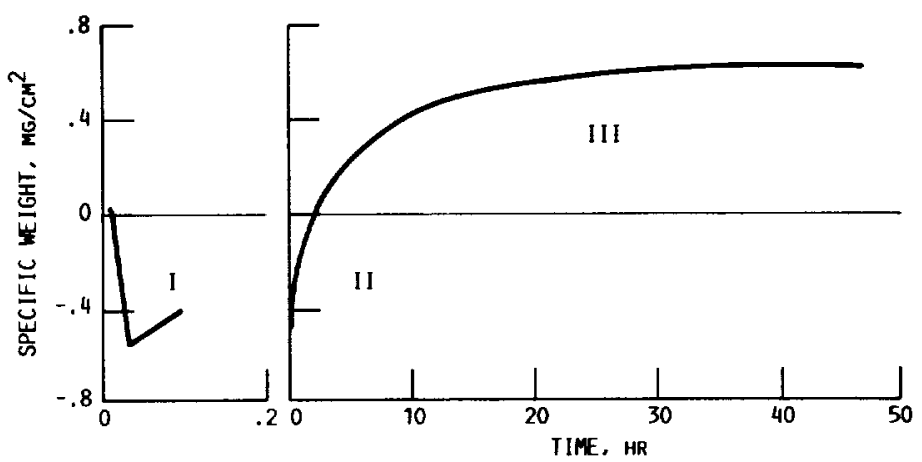

(a) THERMOGRAVIMETRIC AMALYSIS.

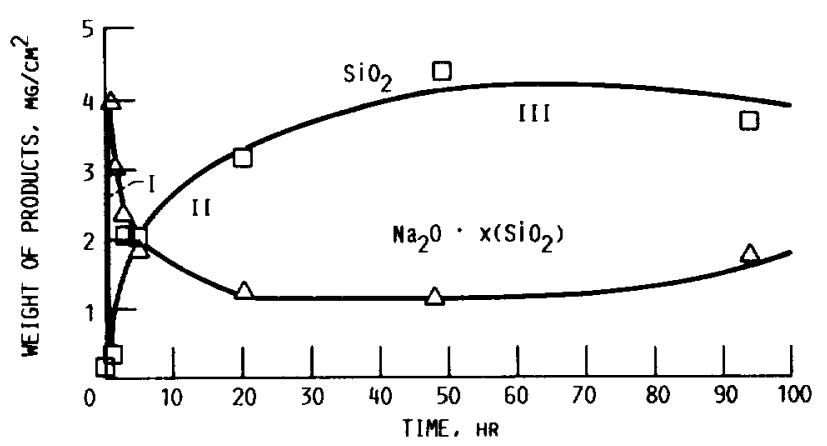

(b) CHEMICAL AMALYSIS.

FIGURE 8. - KINETIC CURVES FOR THE REACTION OF SASC (B,C)

$+\mathrm{Na}_{2} \mathrm{CO}_{3} / \mathrm{O}_{2}$ AT $1000{ }^{\circ} \mathrm{C}$. 


\section{ORIANAL PAOE IS \\ OF. POOF QUI:ITY}
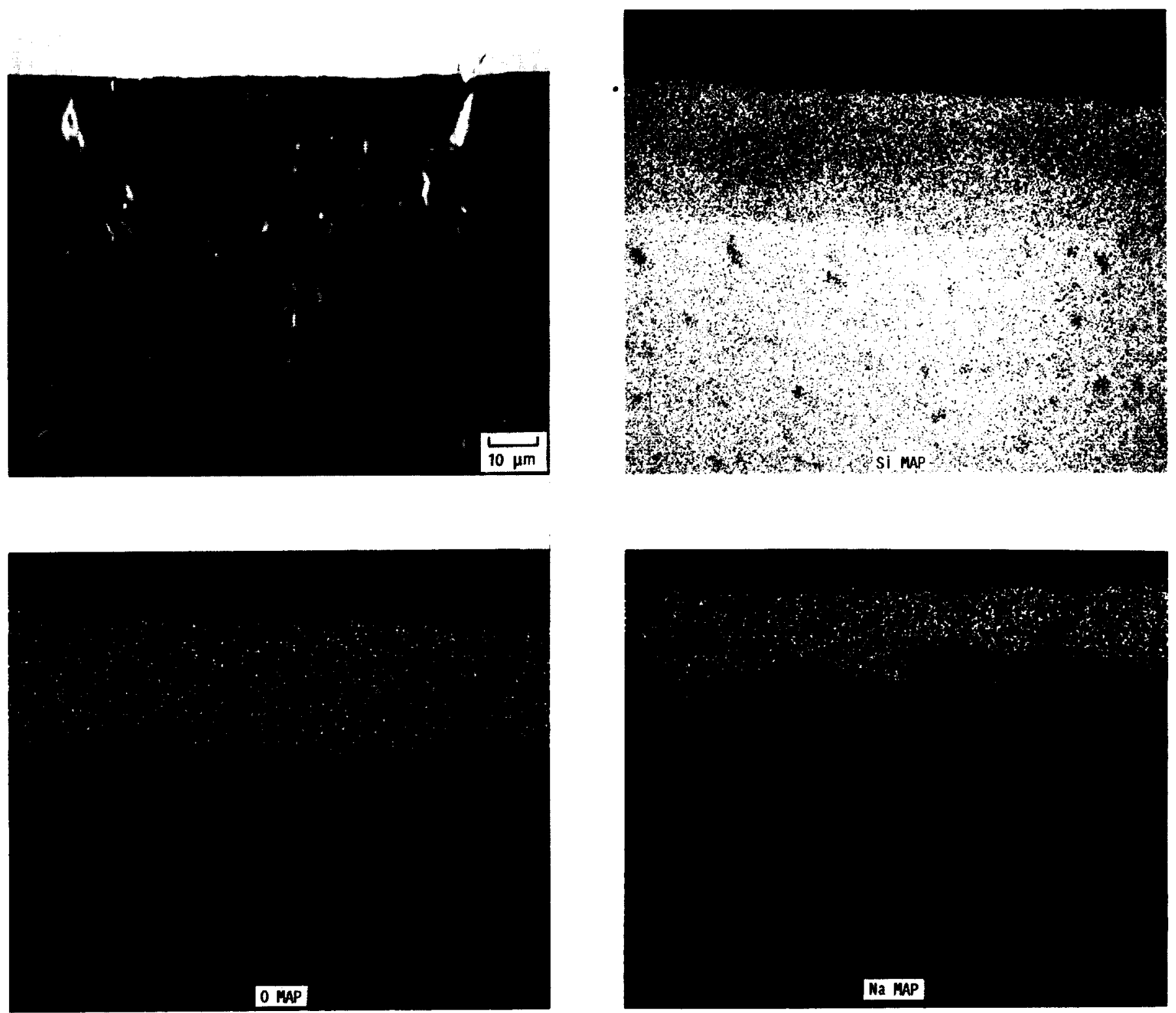

FIGURE 9. - ELECTRON MICROPROBE ANALYSIS OF A POLISHED CROSS SECTION OF CORROSION PRODUCTS FORMED FROM THE REACTION OF SASC (B,C) $+\mathrm{Na}_{2} \mathrm{CO}_{3} / \mathrm{O}_{2}$ AT $1000{ }^{\circ} \mathrm{C}$ FOR $48 \mathrm{HR}$. 

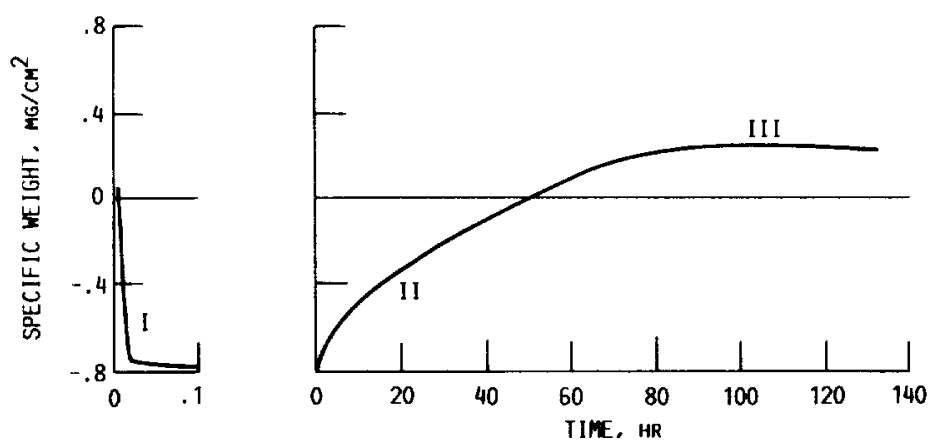

FIGURE 10. - TGA CURVE FOR SSN $\left(\mathrm{Y}_{2} \mathrm{O}_{3}\right)+\mathrm{Na}_{2} \mathrm{CO}_{3} / \mathrm{O}_{2}$ AT $1000{ }^{\circ} \mathrm{C}$.

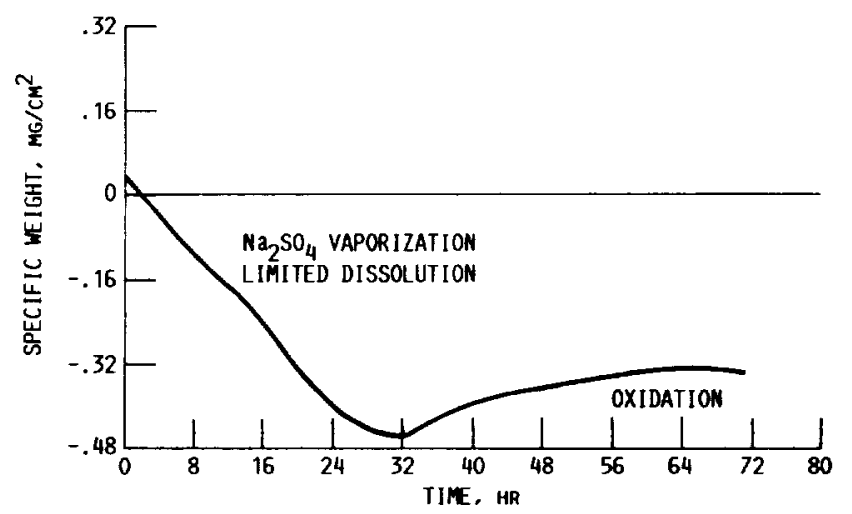

FIGURE 11. - TGA CURVE FOR HIP RBSN + $\mathrm{Na}_{2} \mathrm{SO}_{4} / \mathrm{O}_{2}$ AT $1000{ }^{\circ} \mathrm{C}$.

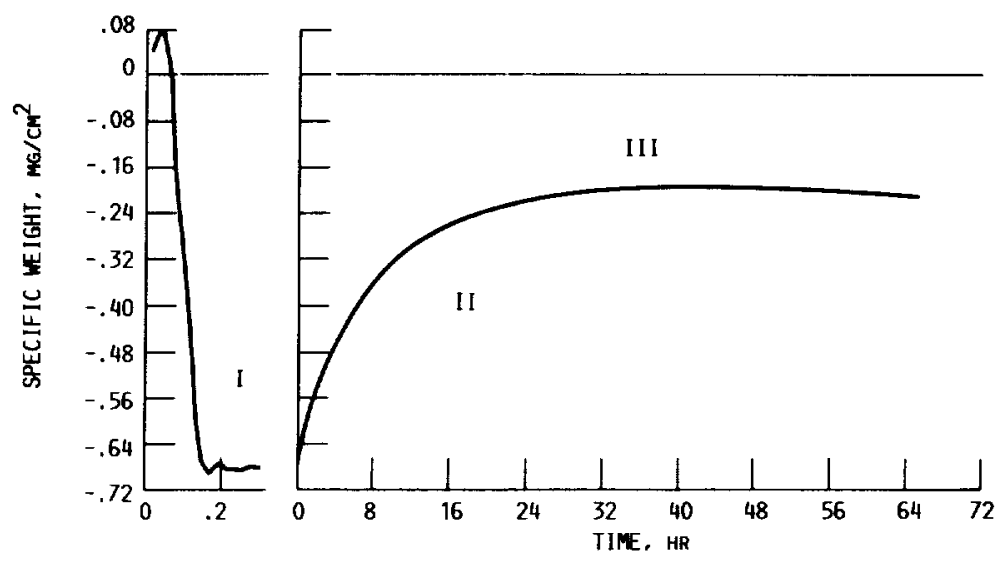

FIGURE 12. - TGA CURVE FOR SASC (B.C) + $\mathrm{Na}_{2} \mathrm{SO}_{4} / \mathrm{O}_{2}$ AT $1000^{\circ} \mathrm{C}$. 


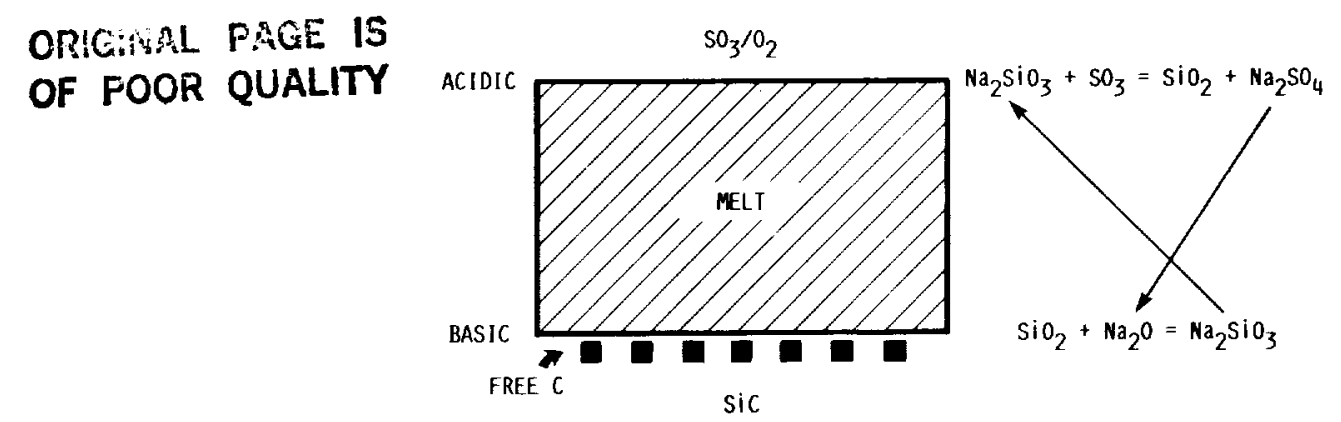

FIGURE 13. - SCHEMATIC OF FLUXING MECHANISM OPERATIVE IN SASC $(B, C)$ $+\mathrm{Na}_{2} \mathrm{SO}_{4} / \mathrm{SO}_{3}$
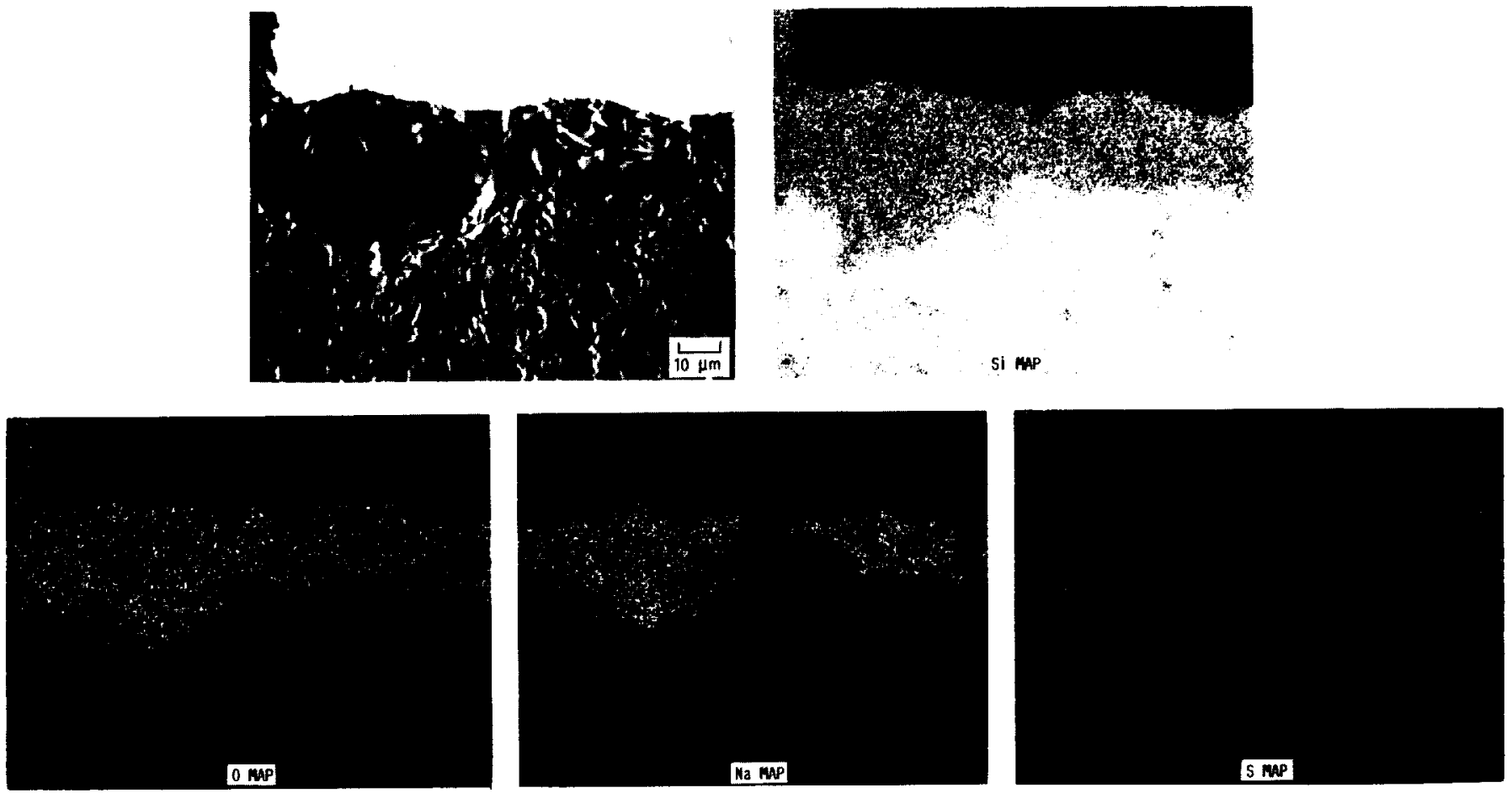

FIGURE 14. - ELECTRON MICROPROBE ANALYSIS OF A POLISHED CROSS SECTION OF CORROSION PRODUCTS FORMED FROM THE REACTION OF SASC (B,C) $+\mathrm{Na}_{2} \mathrm{SO}_{4} / \mathrm{SO}_{3}$ AT $1000{ }^{\circ} \mathrm{C}$ FOR $20 \mathrm{HR}$.

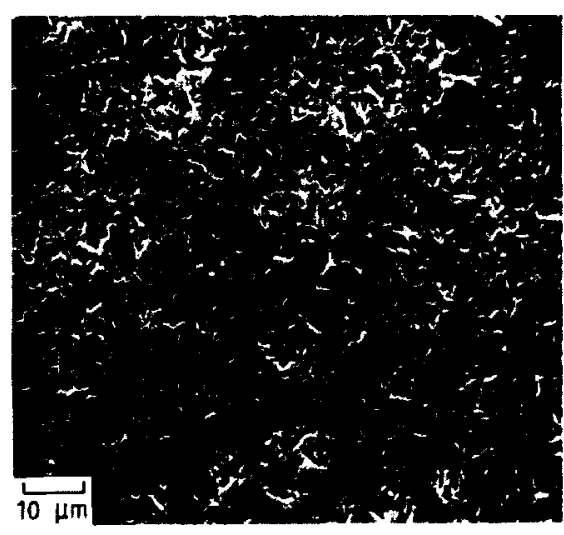

BEFORE CORROSION

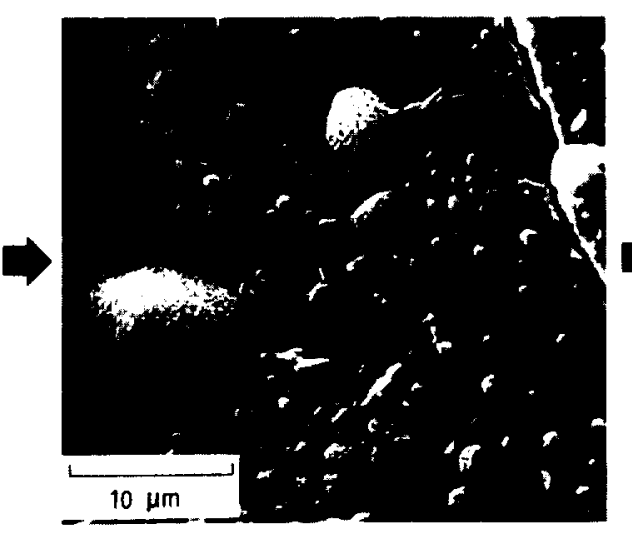

AFTER CORROSION

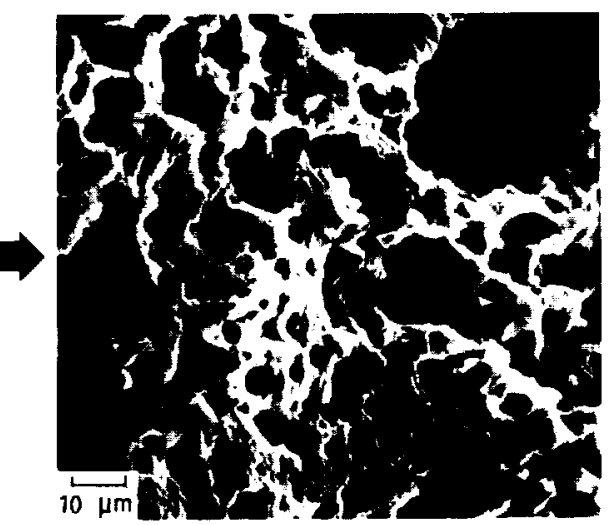

PRODUCTS REMOVED WITH HF

FIGURE 15. - SEQUENCE SHOWING SASC (B.C) BEFORE CORROSION, AFTER CORROSION WITH Na $\mathrm{SO}_{4} / \mathrm{SO}_{3}$ AT $1000{ }^{\circ} \mathrm{C}$ FOR 48 HR. AND WITH THE CORROSION PRODUCTS REMOVED WITH HF. 


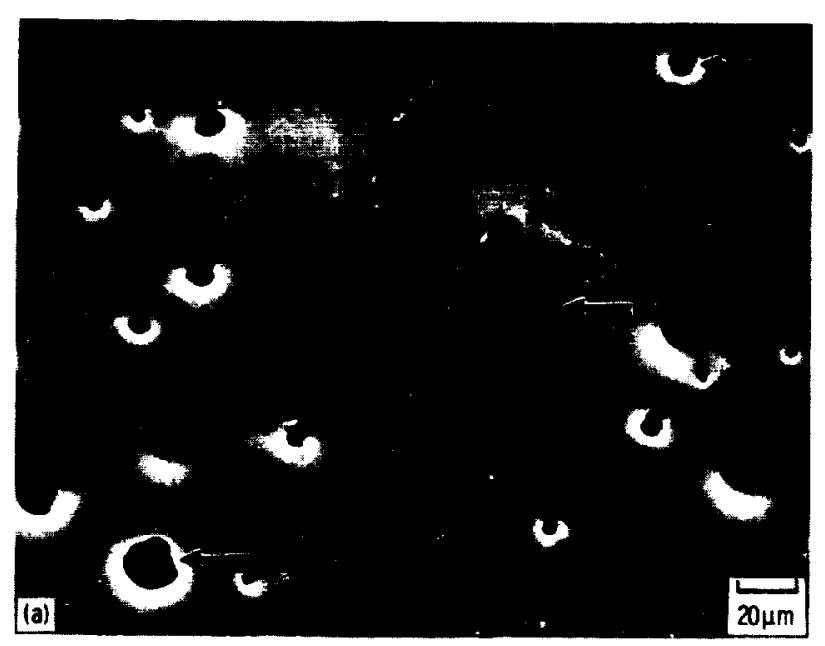

(a) AS-CORRODED SURFACE SIIOWS BUBBLES AND PORES IN THE SILICAIE LAYER.

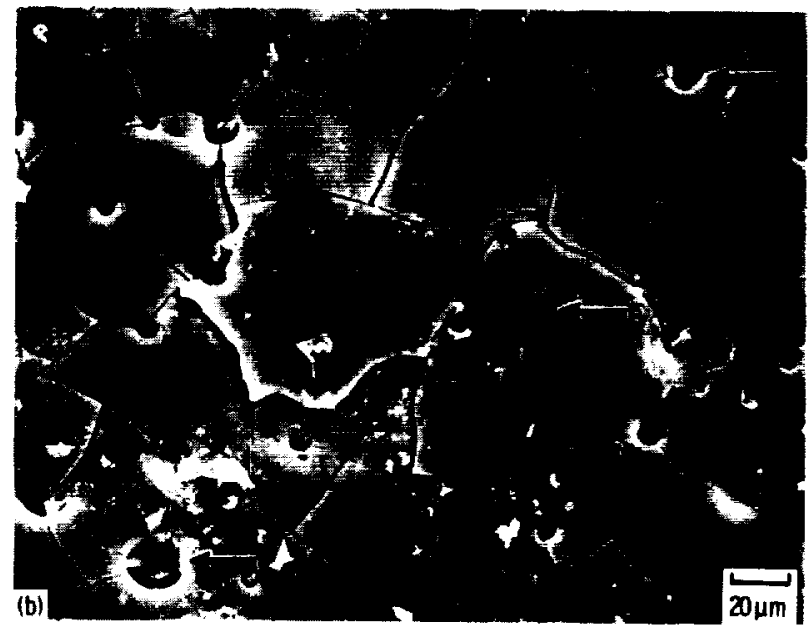

(b) WAIER LEACH REVEALS BUBBLES AMD PORES IN IHE SILICA LAYER.

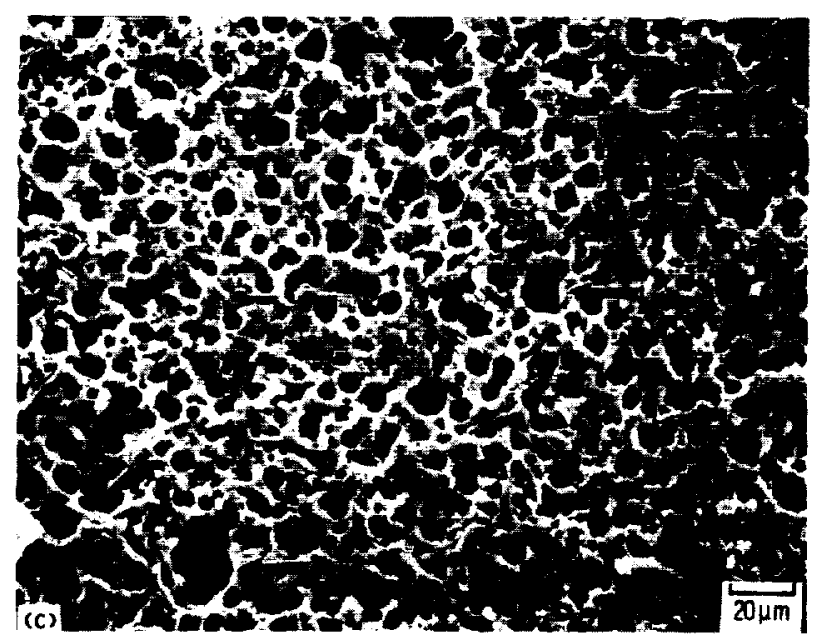

(c) IF LEACH SHOWS IHE CORRELATION OF IHESE BUBBLES AND PORES TO SOME OF THE PITS IN THE CERAMIC, AS SHOWN BY IHE. IHREE ARROWS.

FIGURE 16. - SEM PHOTOS OF SASC (B,C) $+4.07 \mathrm{MG} \mathrm{Na} 2 \mathrm{CO}_{3} / \mathrm{CM}^{2}$ REACTED FOR 1 HR AT $1000{ }^{\circ} \mathrm{C}$.

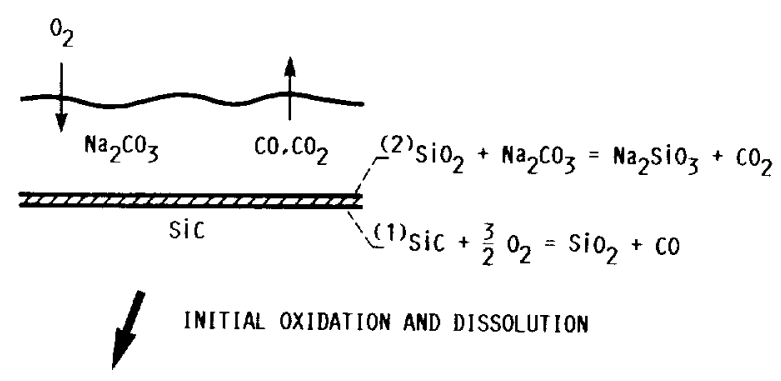

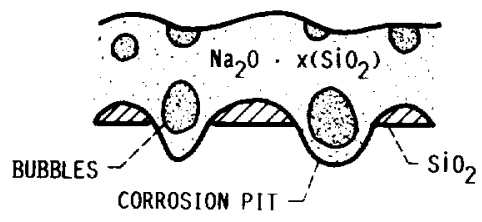

GAS BUBBLES AND PIT FORMAIION

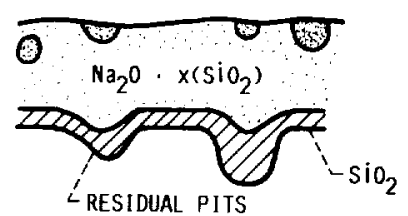

MELT SATURATION AND HEAL ING LAYER

FIGURE 17. - SCHEMATIC OF PROPOSED PITTING MECHANISM IN SIC VIA BUBBLES. 


\section{ORIGINAL FAGE IS OE POOR QUALITY}

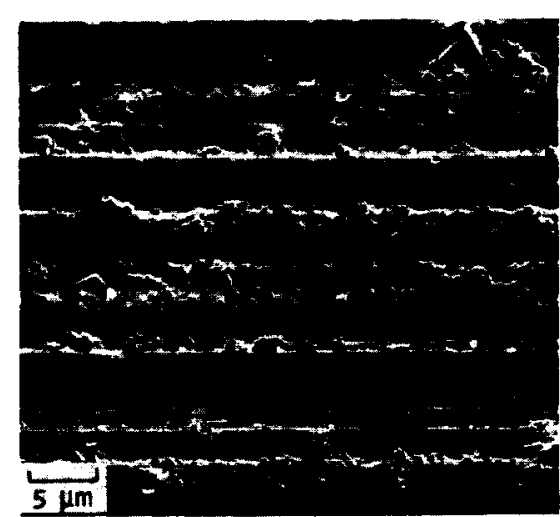

BEFORE CORROSION

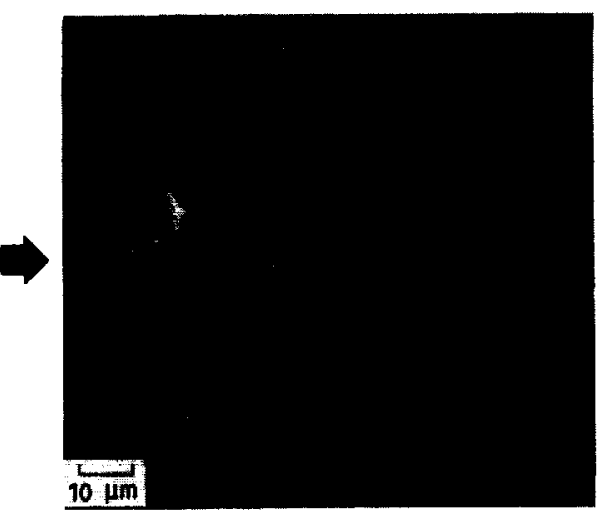

AFTER CORROSION

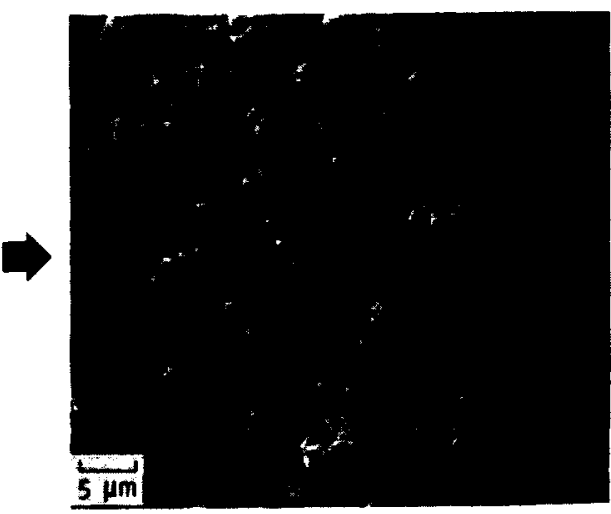

PRODUCTS REMOVED WITH HF

FIGURE 18. - SEQUENCE SHOWING SSN $\left(\mathrm{Y}_{2} \mathrm{O}_{3}, \mathrm{Al}_{2} \mathrm{O}_{3}\right)$ BEFORE CORROSION. AFTER CORROSION WITH Na $\mathrm{SO}_{4} / \mathrm{O}_{2}$ AT $1000{ }^{\circ} \mathrm{C}$ FOR 48 HR. AND WITH THE CORROSION PRODUCTS REMOVED WITH A MILD HF TREATMENT.
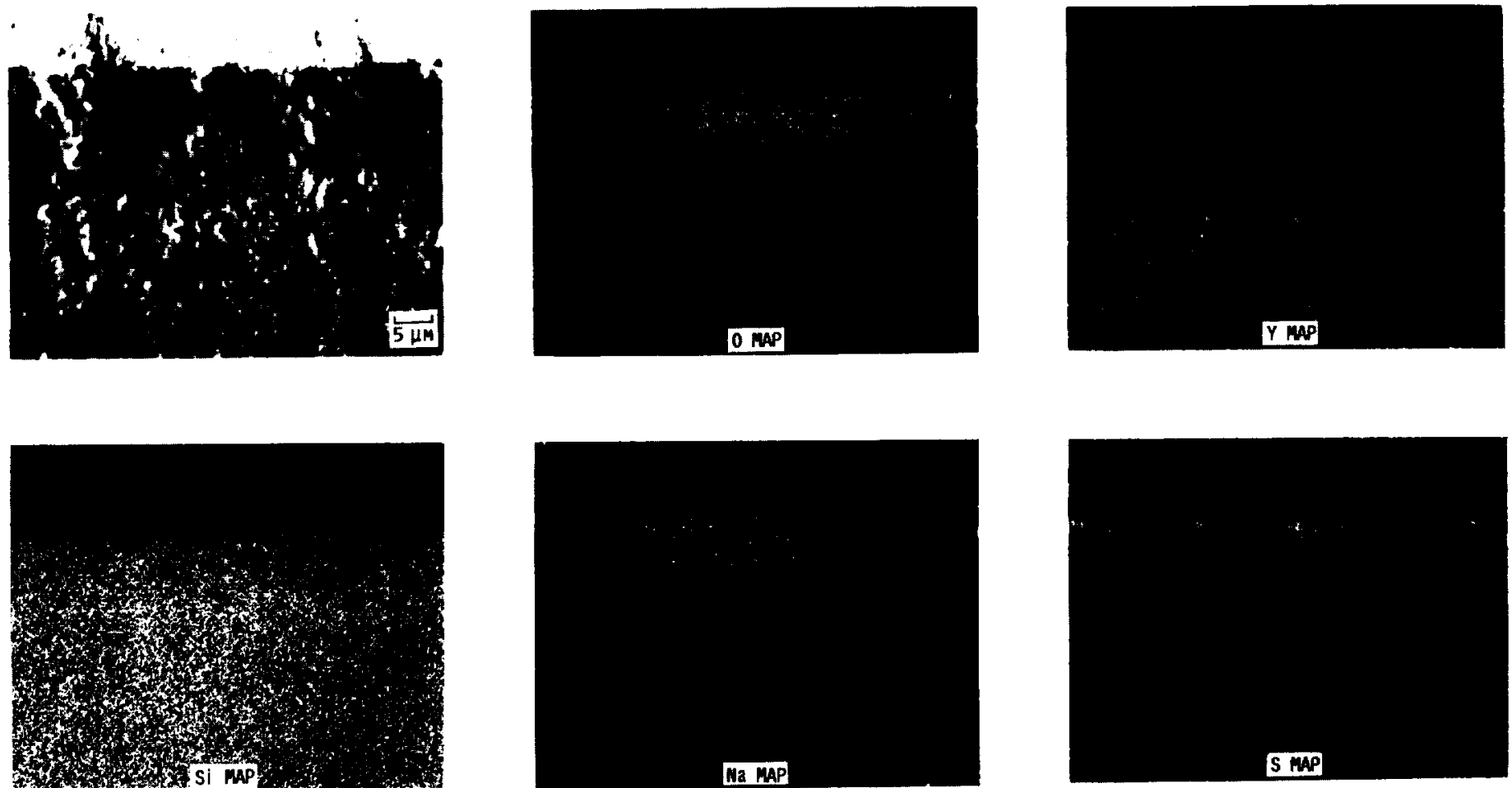

FIGURE 19. - ELECTRON MICROGRAPHS ANALYSIS SHOWING Y DEPLETION IN OUTER REGIONS OF SSN $\left(\mathrm{Al}_{2} \mathrm{O}_{3}, \mathrm{Y}_{2} \mathrm{O}_{3}\right)$ WHEN REACTED WITH Na $2 \mathrm{SO}_{4} / \mathrm{O}_{2}$ FOR 48 HR AT $1000^{\circ} \mathrm{C}$. 


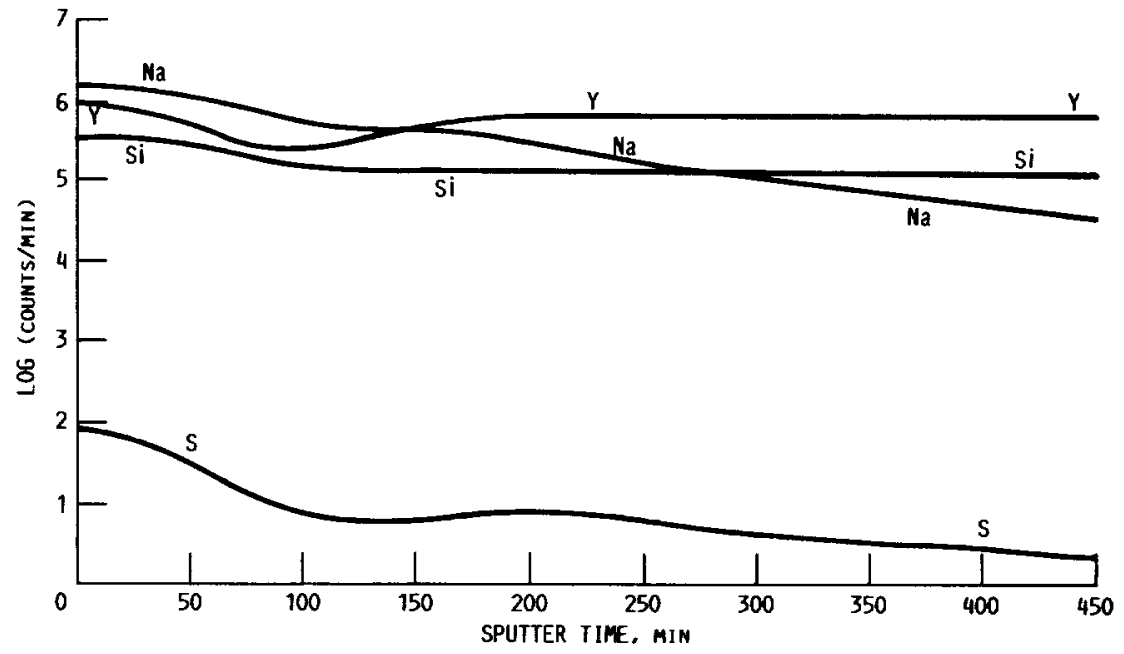

FIGURE 20. - SIMS PROFILE FOR SSN $\left(\mathrm{Al}_{2} \mathrm{O}_{3}, \mathrm{Y}_{2} \mathrm{O}_{3}\right)+\mathrm{Na}_{2} \mathrm{SO}_{4} / \mathrm{O}_{2}$ REACTED AT $1000{ }^{\circ} \mathrm{C}$ FOR 48 HR. ANGLE LAPPED SPECIMEN, PROF IL IMG STARTED AI SCALE/WITRIDE INTERFACE, FOR A TOTAL DEPTH OF 45 IM AFTER 450 MIN SPUTTER TIME.

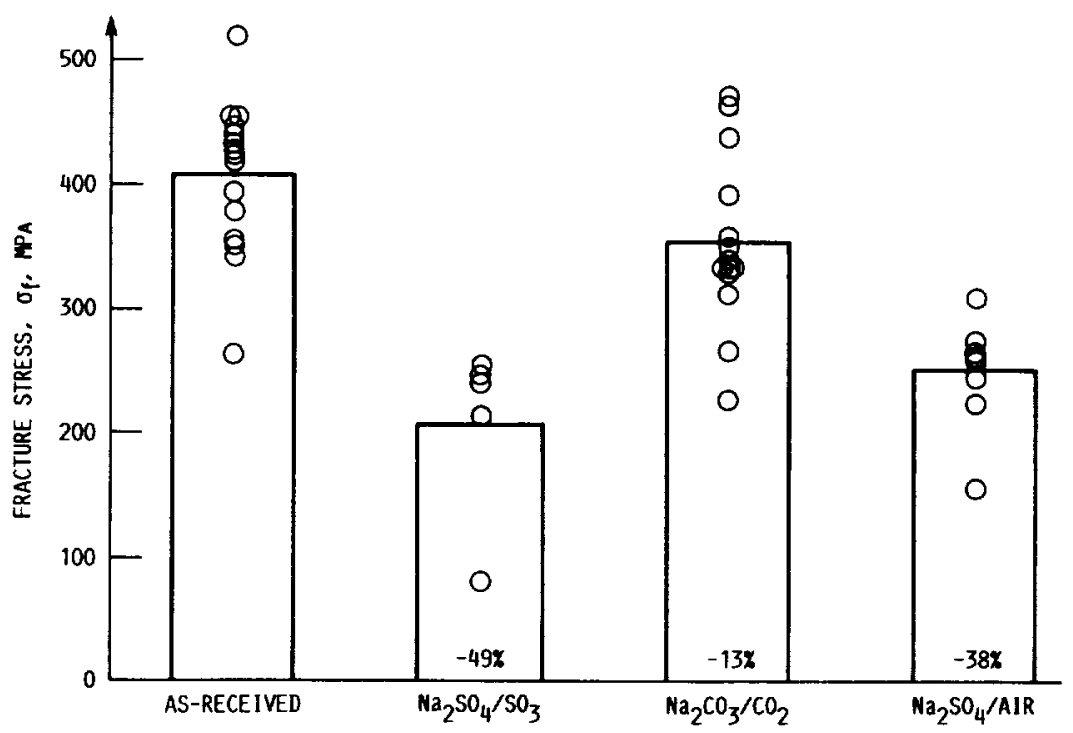

FIGURE 21. - STREMGTH DEGRADATION OF SASC (B,C) AFTER FURNACE CORROSION TESTIMG FOR 48 HR AT $1000^{\circ} \mathrm{C}$. 


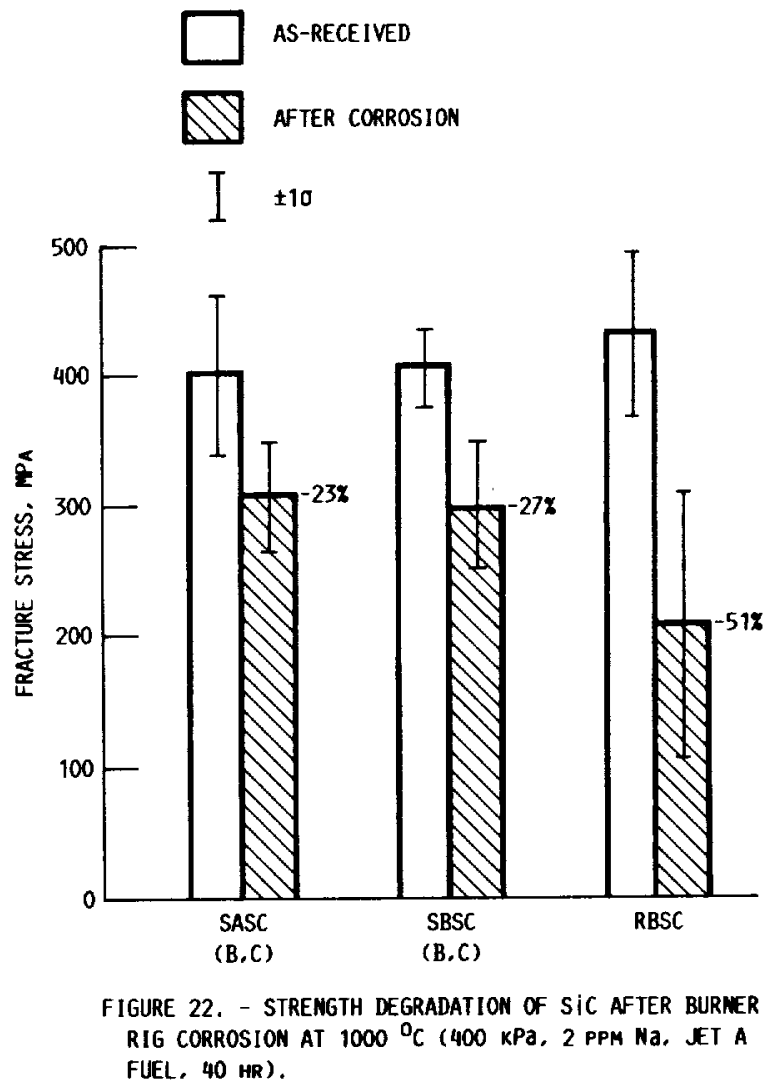




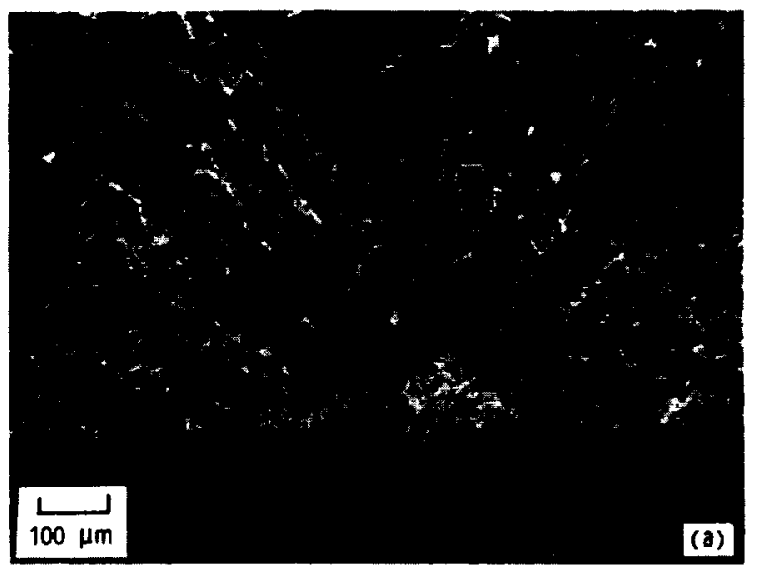

(a) RADIAL CRACK LIMES EXIENDING TO THE ORIGIN.

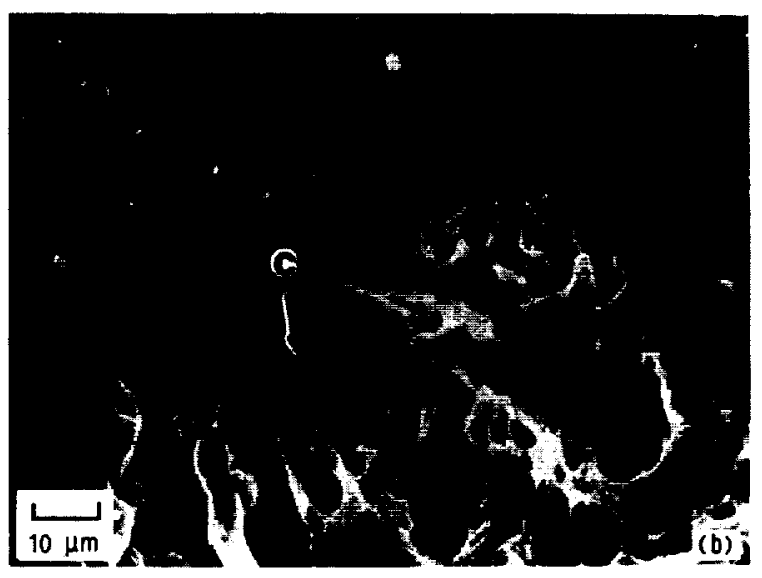

(b) HONEYCOMB CORROSION PIT AT THE ORIGIN.

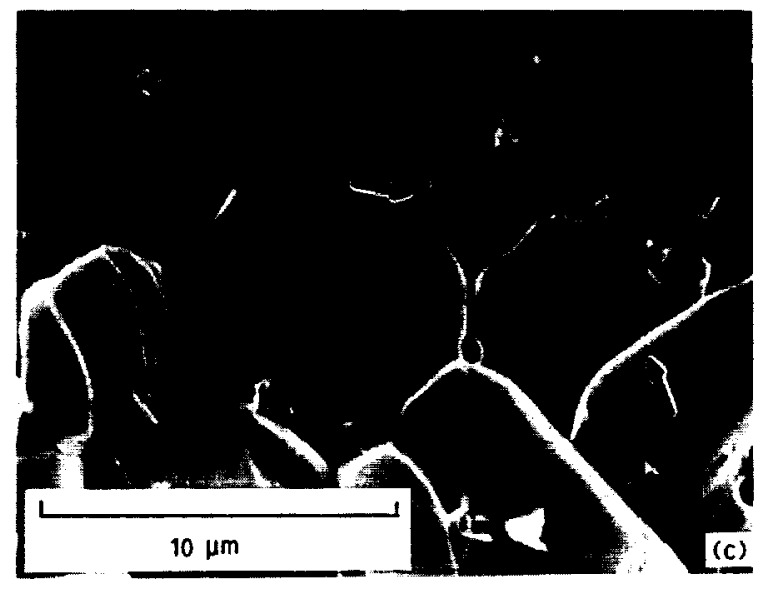

(c) PREFERENTIAL GRAIN BOUNDARY ATTACK AHEAD OF PIT IN (B).

FIGURE 23. - CORROSION PIT FRACTURE ORIGIN IN SASC (B.C) AFTER $\mathrm{Na}_{2} \mathrm{SO}_{4} / \mathrm{SO}_{3}$ CORROSION AT $1000^{\circ} \mathrm{C}$ FOR 48 HR. 


\section{CRIGINAL PAGE IS \\ OF POOR QUALITY}

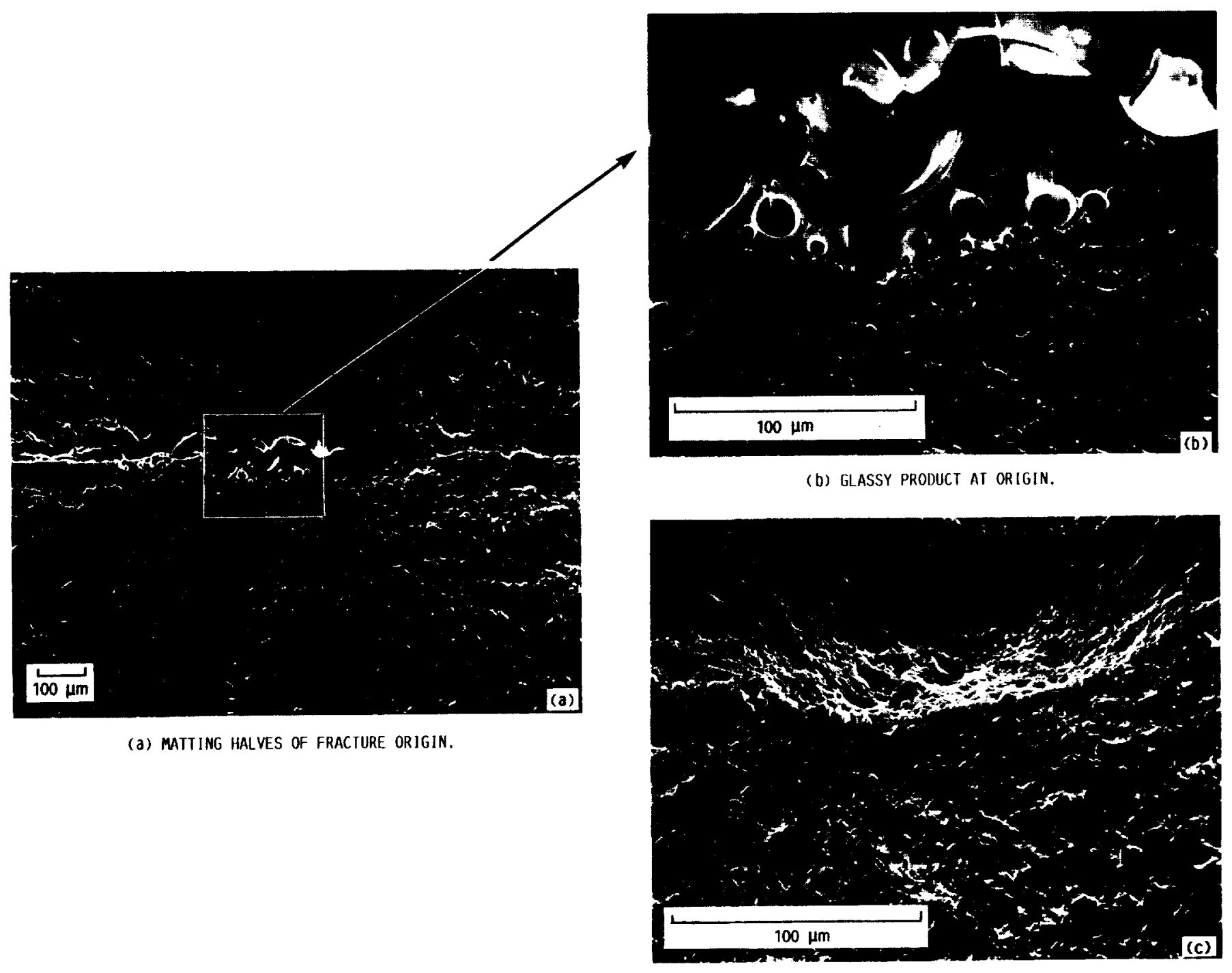

(c) PITTING AT ORIGIN REVEALED BY HF DISSOLUTION OF GLASSY PRODUCT.

FIgURE 24. - CORROSION PIT FRACTURE ORIGIN FOR A BURNER RIG CORRODED SASC (B.C) USING JET A FUEL, 4 PPM Na, 13.5 HR EXPOSURE AT $1000{ }^{\circ} \mathrm{C}$. 


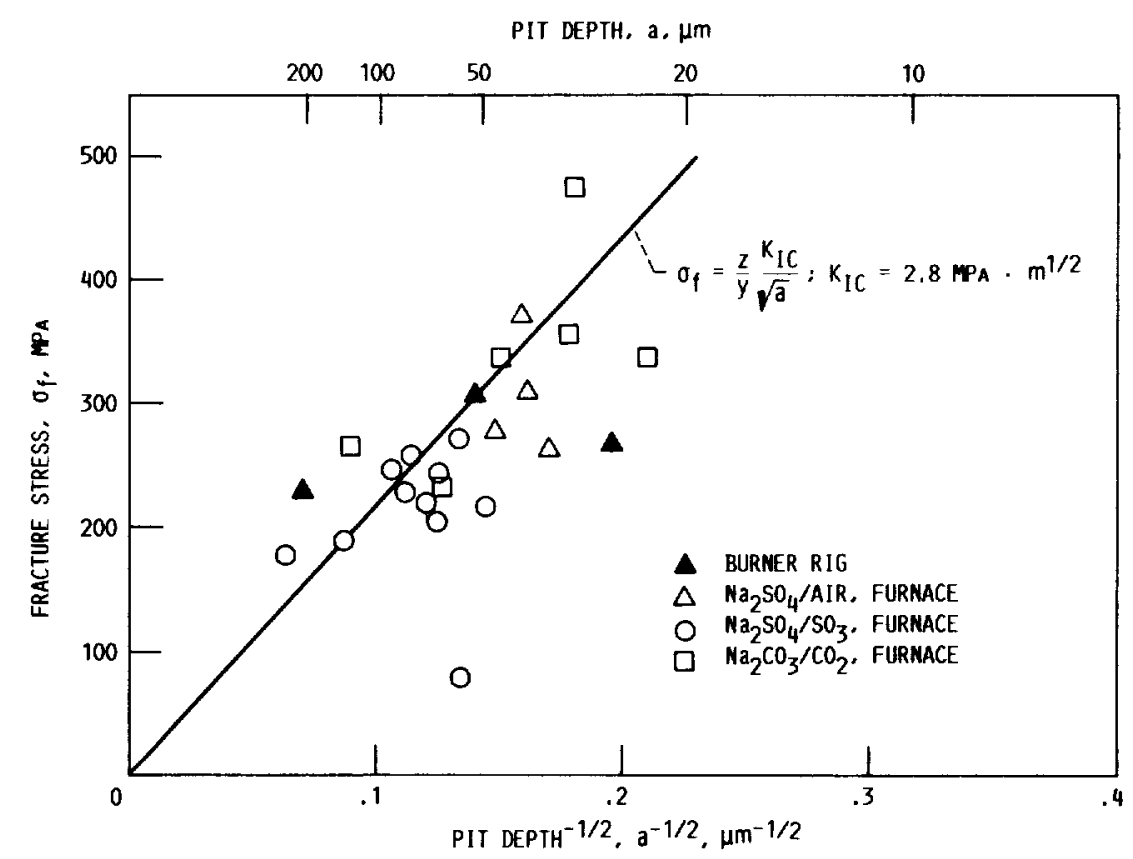

FIGURE 25. - CORRELATION OF FRACTURE STRENGTH WITH CORROSION PIT DEPTH, SASC (B.C) CORRODED IN BOTH THE FURMACE AND BURRER RIG.

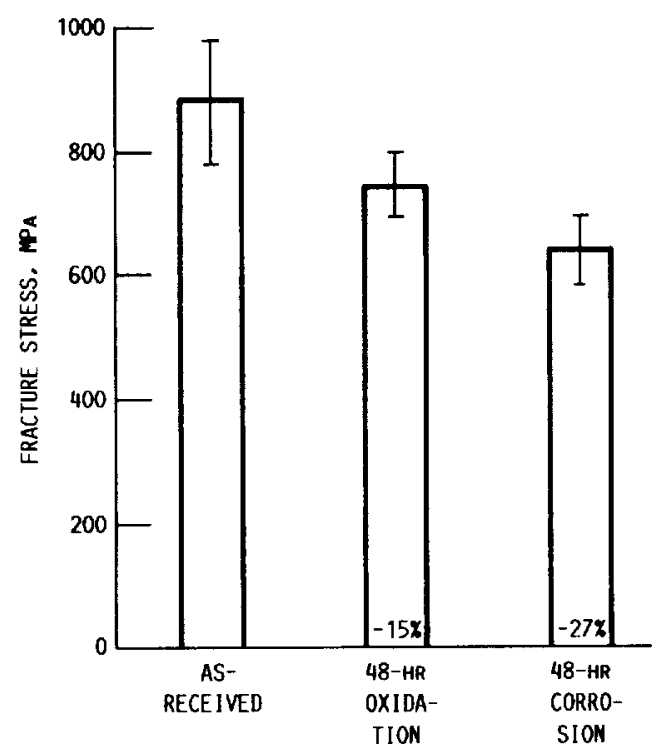

(a) $\operatorname{SSN}\left(\mathrm{Al}_{2} \mathrm{O}_{3}, \mathrm{Y}_{2} \mathrm{O}_{2}\right)$.

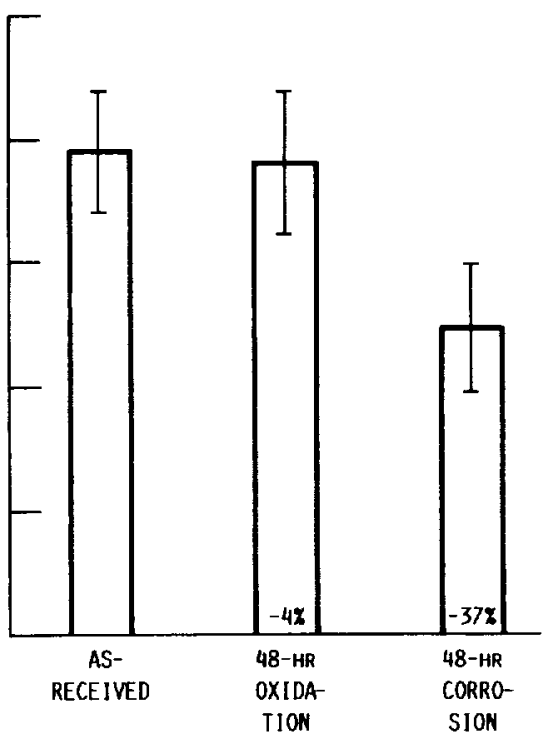

(b) $\operatorname{SSN}\left(\mathrm{Y}_{2} \mathrm{O}_{3}\right)$

FIGURE 26. - ROOM tEMPERATURE STRENGTHS. EACH MATERIAL AFTER 48 HR OF OXIDATION AT $1000{ }^{\circ} \mathrm{C}$. AND EACH MATERIAL AFTER 48 HR OF CORROSION WITH $\mathrm{Na}_{2} \mathrm{SO}_{4} / \mathrm{O}_{2}$ AT $1000{ }^{\circ} \mathrm{C}$. 


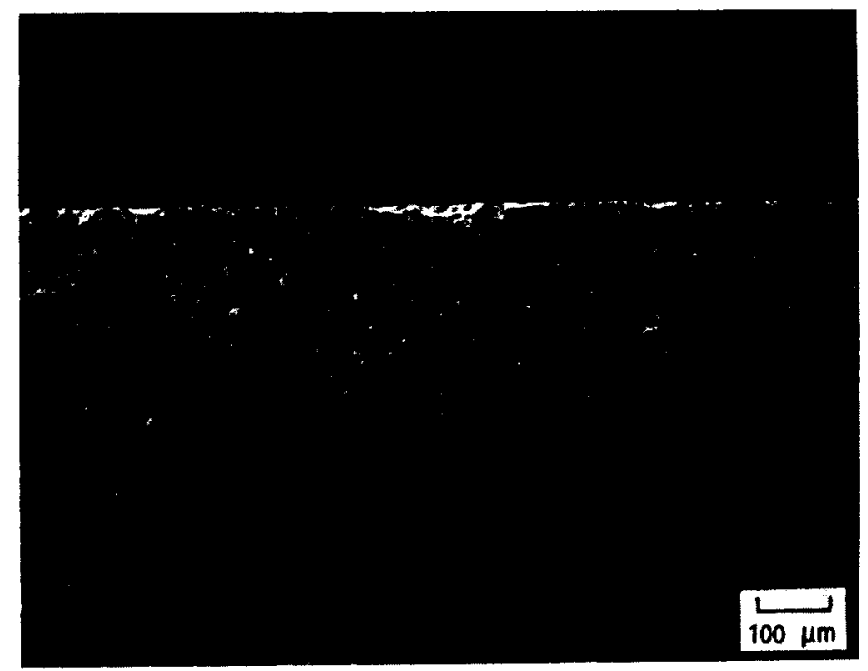

(a) OVERALL VIEW.

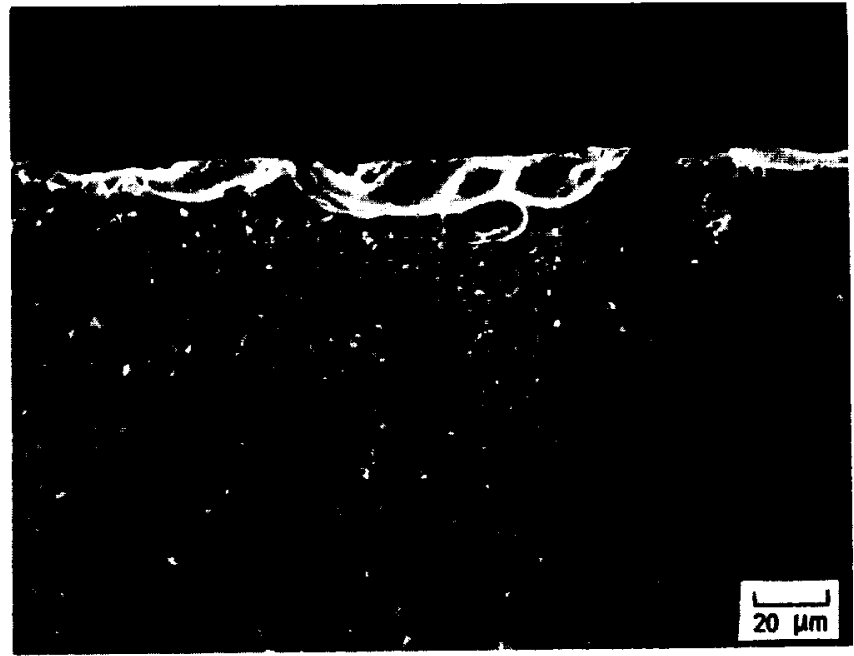

(b) ENLARGEMENT OF CORROSION SCALE AND BUBBLES AT ORIGIN. FIGURE 27. - FRACTURE ORIGIN FOR SSN $\left(\mathrm{Al}_{2} \mathrm{O}_{3} \cdot \mathrm{Y}_{2} \mathrm{O}_{3}\right)+\mathrm{Na}_{2} \mathrm{SO}_{4} / \mathrm{O}_{2}$ CORRODED AT $1000{ }^{\circ} \mathrm{C}$ FOR $48 \mathrm{HR}$.

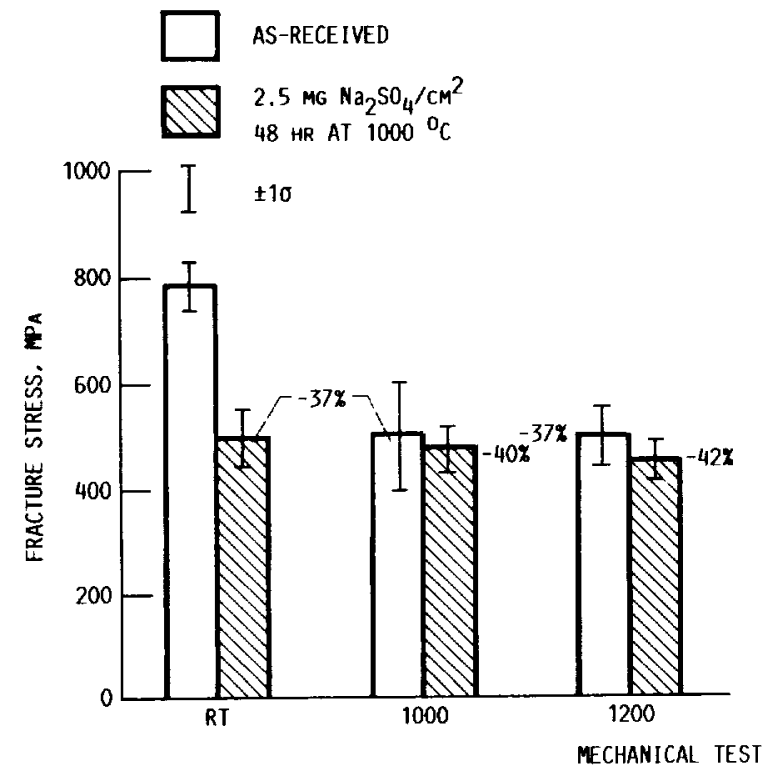

(a) $\operatorname{SSN}\left(\mathrm{A}_{2} \mathrm{O}_{3}, \mathrm{Y}_{2} \mathrm{O}_{3}\right)$.

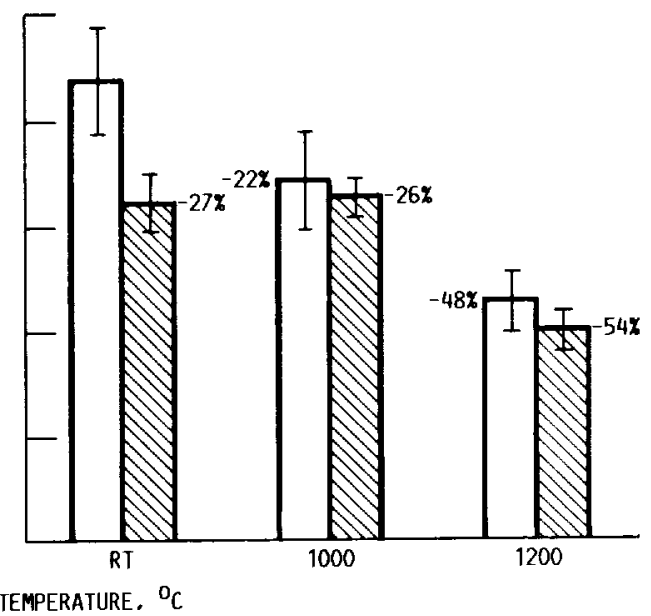

(b) $\operatorname{SSN}\left(\mathrm{Y}_{2} \mathrm{O}_{3}\right)$.

FIGURE 28. - STRENGTH AND AS-RECEIVED AND CORRODED SSN MATERIALS AT ROOM IEMPERATURE, 1000 AND $1200{ }^{\circ} \mathrm{C}$. 


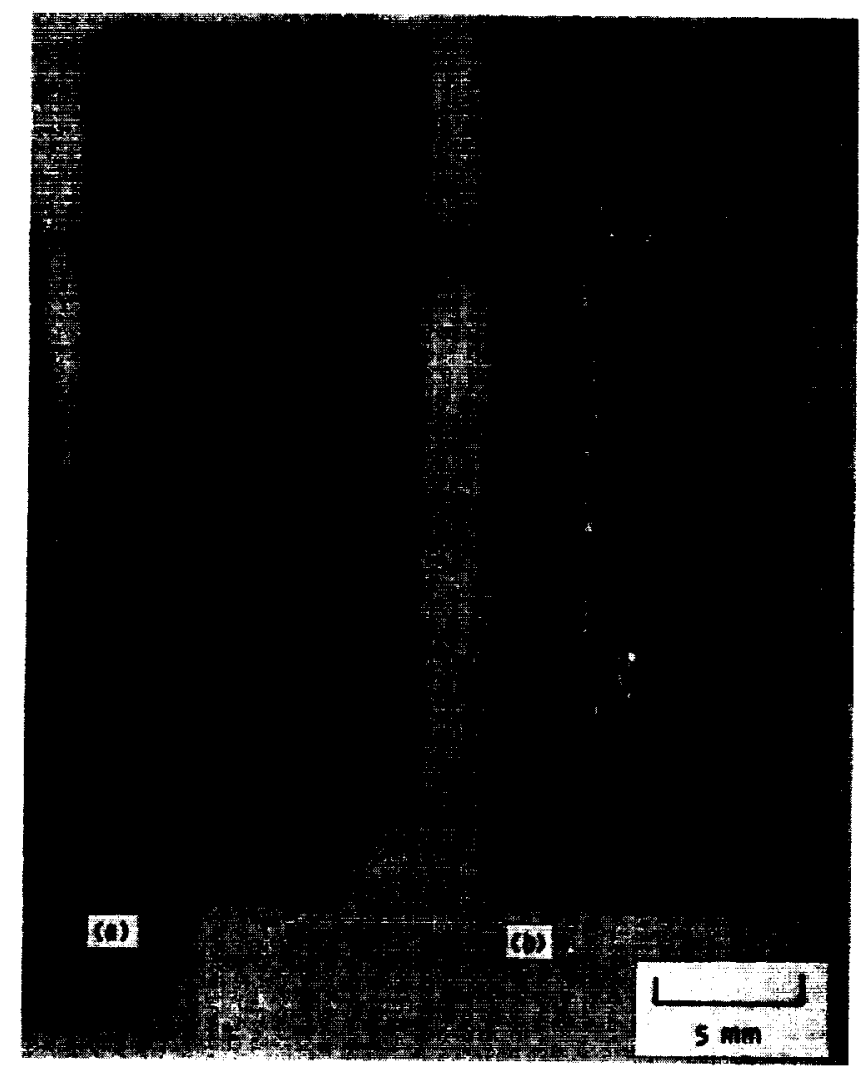

(a) WITH A DENSE MULLIIE

(b) UNCOATED. PLASMA SPRAYED COATING.

FIGURE 29. - VIEHS OF SASC (B.C) IESTED IN THE BURMER RIG WIIH JFT A FUEL, 2 PPM Na, AT $1000^{\circ} \mathrm{C}$ FOR 20 HR. 


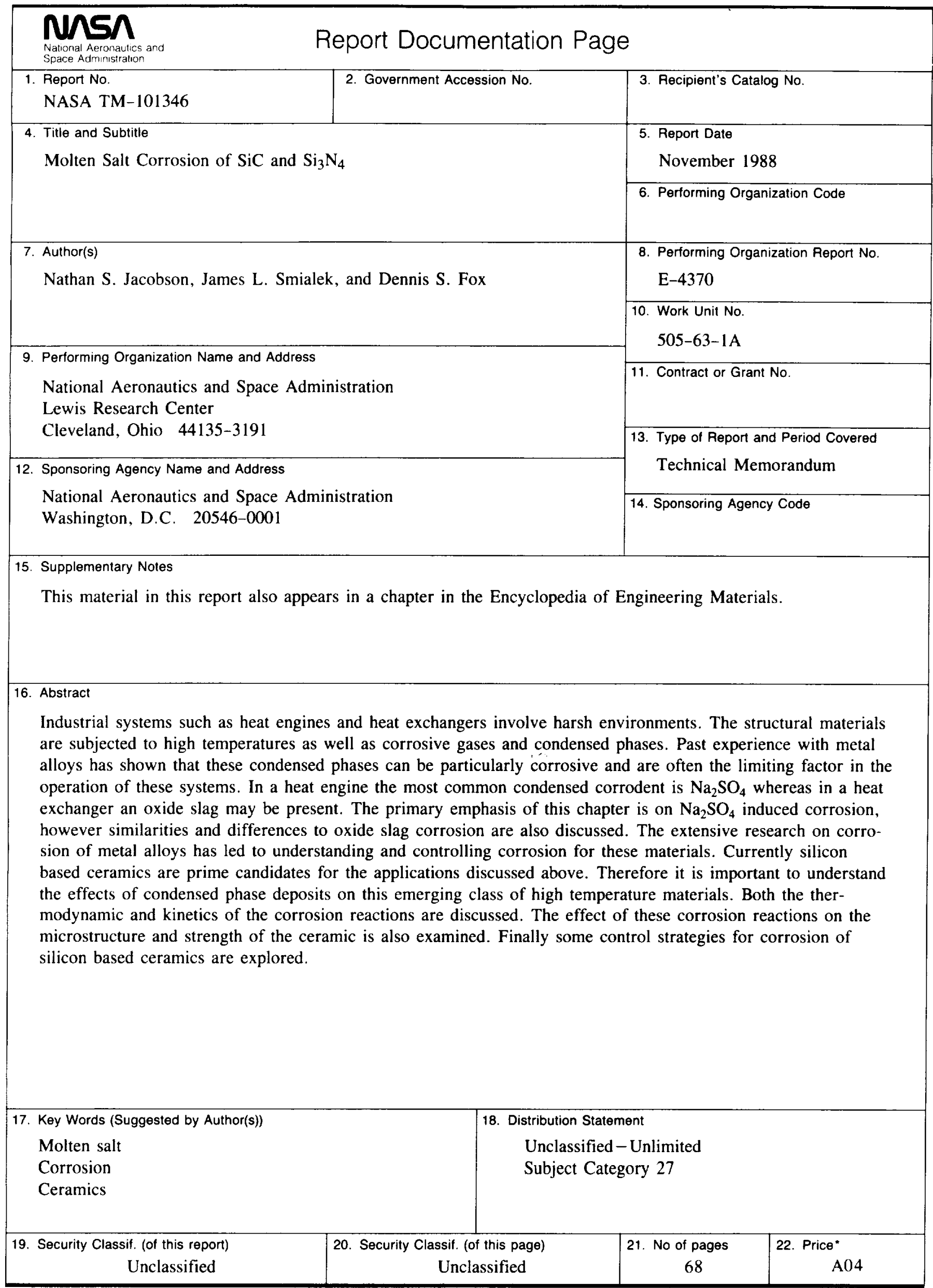


